Prepared in Cooperation with Utah Department of Natural Resources, Bureau of Land Management, and Central Iron County Water Conservancy District

\title{
Hydrogeologic and Geochemical Characterization of Groundwater Resources in Pine and Wah Wah Valleys, Iron, Beaver, and Millard Counties, Utah
}

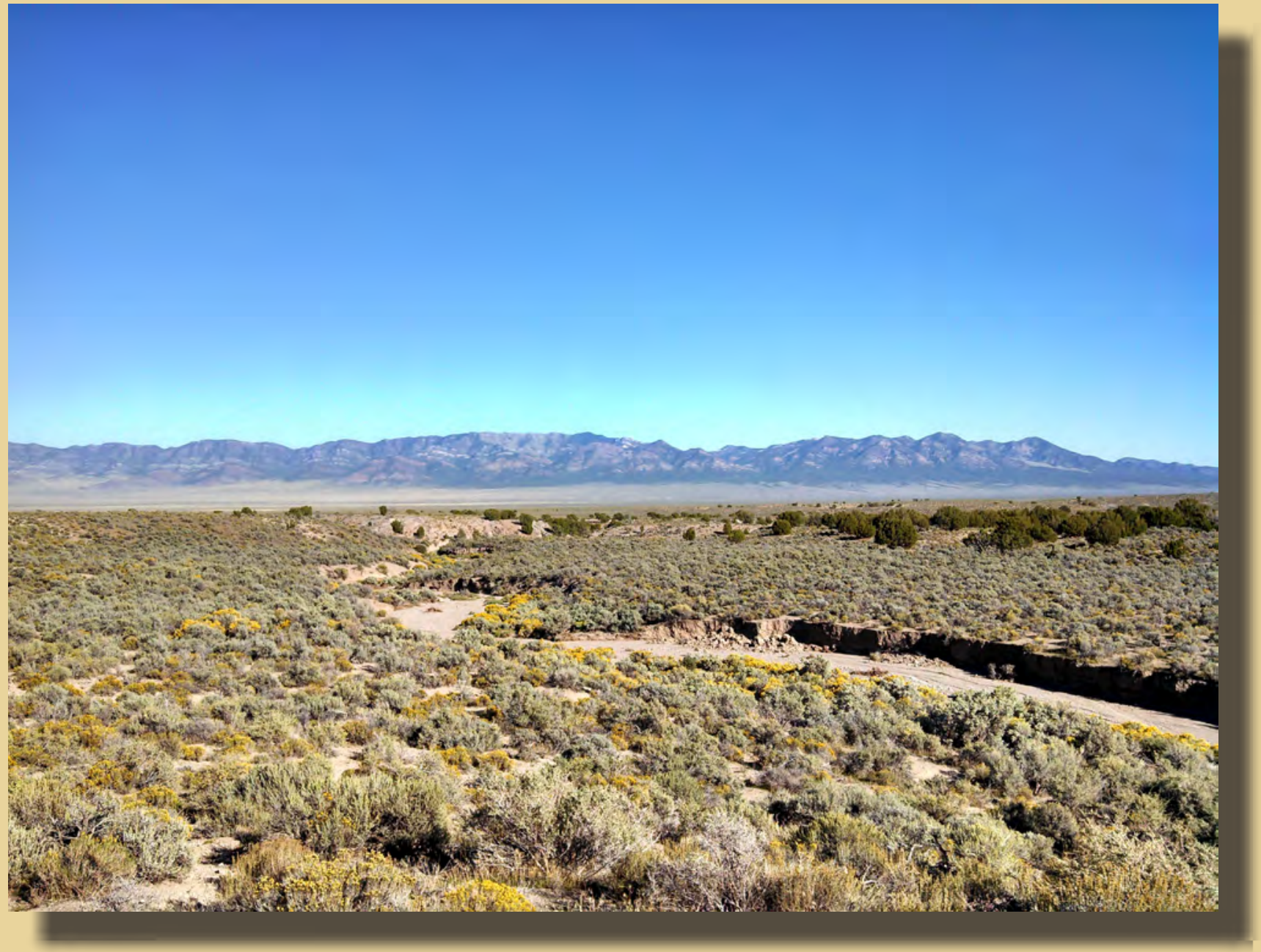

Scientific Investigations Report 2019-5139 
Cover: Looking east across Pine Valley to the Wah Wah Mountains from near Willow Spring. Photograph by Philip Gardner, September 2013 


\section{Hydrogeologic and Geochemical Characterization of Ground water Resources in Pine and Wah Wah Valleys, Iron, Beaver, and Millard Counties, Utah}

By Philip M. Gardner, Thomas M. Marston, Susan G. Buto, and Lynette E. Brooks

Prepared in Cooperation with Utah Department of Natural Resources, Bureau of Land Management, and Central Iron County Water Conservancy District

Scientific Investigations Report 2019-5139 


\title{
U.S. Department of the Interior DAVID BERNHARDT, Secretary
}

\author{
U.S. Geological Survey \\ James F. Reilly II, Director
}

U.S. Geological Survey, Reston, Virginia: 2020

For more information on the USGS - the Federal source for science about the Earth, its natural and living resources, natural hazards, and the environment-visit https://www.usgs.gov or call 1-888-ASK-USGS.

For an overview of USGS information products, including maps, imagery, and publications, visit https://store.usgs.gov.

Any use of trade, firm, or product names is for descriptive purposes only and does not imply endorsement by the U.S. Government.

Although this information product, for the most part, is in the public domain, it also may contain copyrighted materials as noted in the text. Permission to reproduce copyrighted items must be secured from the copyright owner.

Suggested citation:

Gardner, P.M., Marston, T.M., Buto, S.G., and Brooks, L.E., 2020, Hydrogeologic and geochemical characterization of groundwater resources in Pine and Wah Wah Valleys, Iron, Beaver, and Millard Counties, Utah: U.S. Geological Survey Scientific Investigations Report 2019-5139, 49 p., https://doi.org/10.3133/sir20195139. 


\section{Acknowledgments}

The authors gratefully acknowledge Hugh Hurlow and Stefan Kirby of the Utah Geological

Survey for providing geochemical data for two wells and five springs in Pine and Wah Wah

Valleys. These data account for nearly one-third of the sample sites discussed in this report and add great value to the geochemical dataset. 


\section{Contents}

Abstract

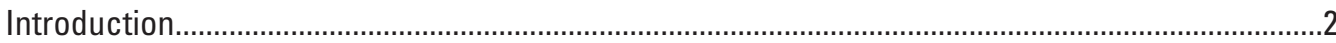

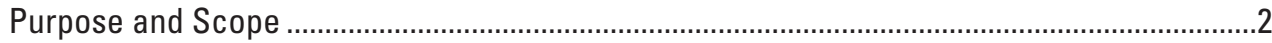

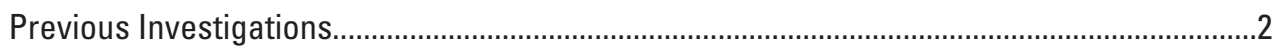

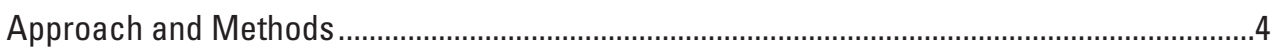

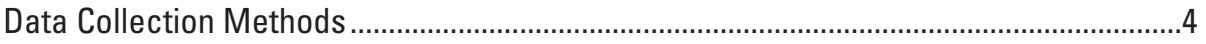

Physical Characteristics of the Study Area .........................................................................

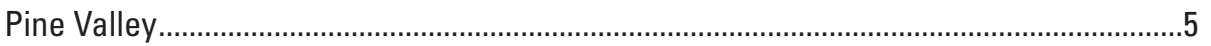

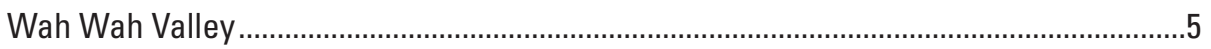

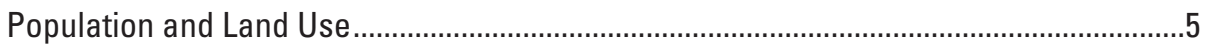

Climate and Precipitation .................................................................................................

Geology

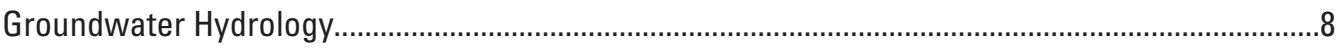

Hydrogeology

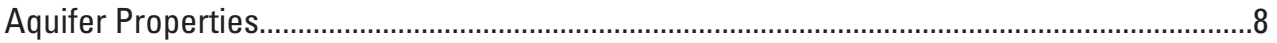

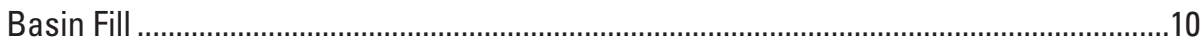

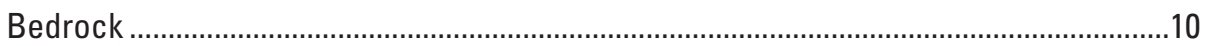

Presence and Movement of Groundwater ............................................................................10

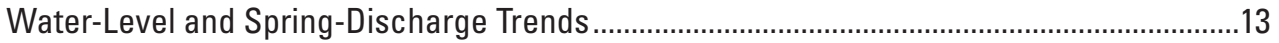

Regional Evapotranspiration Occurring North of the Study Area ..................................................15

Scaling from Site Measurement to Basin-Scale Estimates ...................................................16

Delineation of Groundwater Discharge Areas …………..............................................16

Evapotranspiration Units and Estimates of Groundwater Evapotranspiration................18

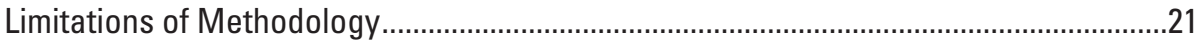

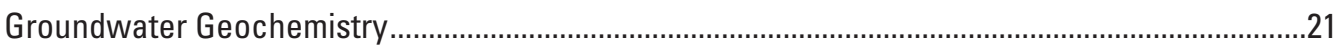

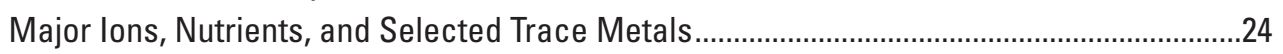

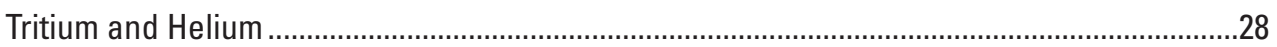

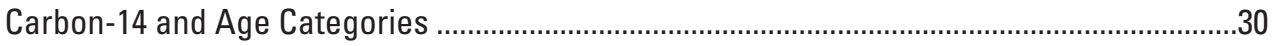

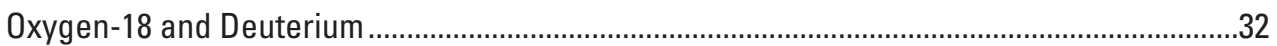

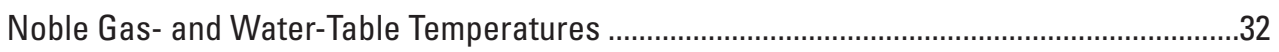

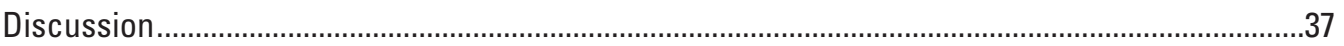

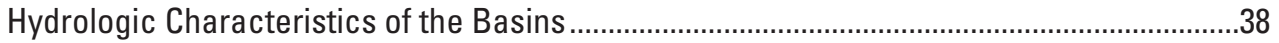

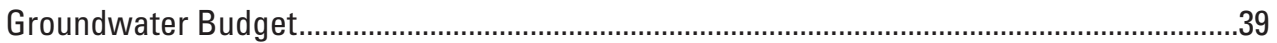

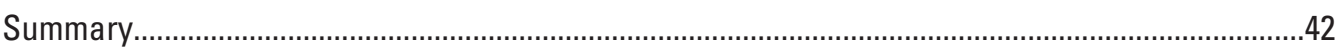

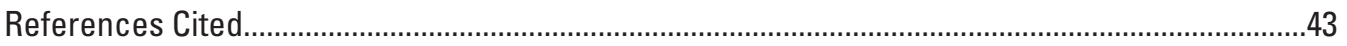

Appendix A: Hydrologic Site Information ............................................................................... 


\section{Figures}

1. Map showing location of Pine and Wah Wah Valleys, Iron, Beaver, and Millard Counties, Utah

2. Map showing average annual precipitation in Pine and Wah Wah Valleys, Utah, 1981-2010.

3. Graph showing average monthly precipitation for weather stations in Pine and Wah Wah Valleys, Utah

4. Map showing the surficial extent of hydrogeologic units and water-level contours indicating the general direction of groundwater movement..

5. Map showing the locations of selected wells and springs with time-series records of water levels or discharge and wells where aquifer transmissivity was estimated in Pine and Wah Wah Valleys, Utah.

6. Graphs showing long-term water-level fluctuations in selected wells in Pine and Wah Wah Valleys, Utah

7. Graphs showing discharge at springs in the mountains of the Pine and Wah Wah Valleys drainage basins, Utah

8. Map showing location and classification of evapotranspiration units used in the calculation of average annual evapotranspiration of groundwater in the Tule Valley and Sevier Lake groundwater discharge areas, Utah.....

9. Graph showing stable isotopes of freshwater and brine showing evaporatively enriched waters in saturated sediments below the Sevier Lake Playa, Utah..

10. Map showing locations of groundwater sample sites and corresponding stiff diagrams showing major-ion composition of groundwater in Pine and Wah Wah Valleys, Utah

11. Piper plot showing major-ion composition of groundwater in Pine and Wah Wah Valleys and surrounding areas, Utah

12. Map showing groundwater-age categories and apparent groundwater ages based on multiple age-related environmental tracers for selected groundwater samples from Pine and Wah Wah Valleys, Utah

13. Graph showing stable-isotope values for selected samples from wells and springs in Pine and Wah Wah Valleys compared to stable-isotope values from seven neighboring basins and ranges of modern cumulative winter and annual precipitation for Pine and Wah Wah Valleys, Utah.

14. Computed noble-gas recharge temperatures compared to measured valley water-table temperatures for groundwater sites sampled in Pine and Wah Wah Valleys, Utah 


\section{Tables}

1. Aquifer properties of basin-fill and bedrock aquifers from selected driller's logs in Pine and Wah Wah Valleys, Utah

2. Ranges of average annual actual evapotranspiration rates for evapotranspiration units in the Tule Valley and Sevier Lake groundwater discharge areas, Utah.

3. Landsat 5 Thematic Mapper scenes evaluated for use in basin-scale estimation of groundwater evapotranspiration in the Tule Valley and Sevier Lake groundwater discharge areas, Utah ....

4. Coefficients of determination describing relations between vegetation indexes and site-scale groundwater evapotranspiration in the Spring, Snake, and White River Valleys, Nevada and Utah

5. Selected attributes of groundwater sites with chemical analyses from Pine and Wah Wah Valleys and surrounding areas, Utah.

6. Measured field parameters and dissolved concentrations of major ions, nutrients, and selected metals for groundwater sampled from Pine and Wah Wah Valleys and surrounding areas, Utah.....

7. Stable- and radio-isotope data used to estimate ages of groundwater sampled from Pine and Wah Wah Valleys, Utah.....

8. Criteria used to assign age categories to groundwater samples from Pine and Wah Wah Valleys, Utah

9. Water temperatures from wells and springs selected to represent the water table in the valley and temperatures from Pine and Wah Wah Valleys, Utah.

10. Dissolved-gas concentrations and related noble-gas temperature data for groundwater sampled from Pine and Wah Wah Valleys, Utah.

11. Summary of conceptual steady-state groundwater budgets reported by Stephens $(1974,1976)$ for Pine and Wah Wah Valleys, Utah

12. Conceptual and simulated steady-state groundwater budgets for the basin-fill aquifers of Pine and Wah Wah Valleys, Utah

A-1. Selected attributes of wells and water levels measured in wells used in constructing the water-level surface map for Pine and Wah Wah Valleys and surrounding areas, Utah..... 


\section{Conversion Factors}

U.S. customary units to International System of Units

\begin{tabular}{|c|c|c|}
\hline Multiply & By & To obtain \\
\hline \multicolumn{3}{|c|}{ Length } \\
\hline inch (in.) & 25.4 & millimeter $(\mathrm{mm})$ \\
\hline foot $(\mathrm{ft})$ & 0.3048 & meter $(\mathrm{m})$ \\
\hline mile (mi) & 1.609 & kilometer (km) \\
\hline \multicolumn{3}{|c|}{ Area } \\
\hline acre & 0.004047 & square kilometer $\left(\mathrm{km}^{2}\right)$ \\
\hline square mile $\left(\mathrm{mi}^{2}\right)$ & 2.590 & square kilometer $\left(\mathrm{km}^{2}\right)$ \\
\hline \multicolumn{3}{|c|}{ Volume } \\
\hline gallon (gal) & 3.785 & liter $(\mathrm{L})$ \\
\hline acre-foot (acre-ft) & 1,233 & cubic meter $\left(\mathrm{m}^{3}\right)$ \\
\hline \multicolumn{3}{|c|}{ Flow rate } \\
\hline acre-foot per year (acre-ft/yr) & 1,233 & cubic meter per year $\left(\mathrm{m}^{3} / \mathrm{yr}\right)$ \\
\hline foot per year (ft/yr) & 0.3048 & meter per year $(\mathrm{m} / \mathrm{yr})$ \\
\hline cubic foot per second $\left(\mathrm{ft}^{3} / \mathrm{s}\right)$ & 0.02832 & cubic meter per second $\left(\mathrm{m}^{3} / \mathrm{s}\right)$ \\
\hline \multicolumn{3}{|c|}{ Specific capacity } \\
\hline gallon per minute per foot $([\mathrm{gal} / \mathrm{min}] / \mathrm{ft})$ & 0.2070 & liter per second per meter $([\mathrm{L} / \mathrm{s}] / \mathrm{m})$ \\
\hline \multicolumn{3}{|c|}{ Hydraulic conductivity } \\
\hline foot per day (ft/d) & 0.3048 & meter per day $(\mathrm{m} / \mathrm{d})$ \\
\hline \multicolumn{3}{|c|}{ Transmissivity } \\
\hline foot squared per day (ft2/d) & 0.09290 & meter squared per day $(\mathrm{m} 2 / \mathrm{d})$ \\
\hline
\end{tabular}

Temperature in degrees Celsius $\left({ }^{\circ} \mathrm{C}\right)$ may be converted to degrees Fahrenheit $\left({ }^{\circ} \mathrm{F}\right)$ as

$$
{ }^{\circ} \mathrm{F}=\left(1.8 \times{ }^{\circ} \mathrm{C}\right)+32 .
$$




\section{Datum}

Horizontal coordinate information is referenced to the North American Datum of 1983 (NAD 83)]. Altitude, as used in this report, refers to distance above the vertical datum.

\section{Supplemental Information}

Concentrations of chemical constituents in water are reported in milligrams per liter (mg/L), micrograms per liter $(\mu \mathrm{g} / \mathrm{L})$, and in milliequivalents per liter. Milligrams per liter and micrograms per liter are units expressing the concentration of chemical constituents in solution as weight (grams) of solute per unit volume (liter) of water. A liter of water is assumed to weigh 1 kilogram, except for brines or water at high temperatures because of changes in the density of the water. For concentrations less than $7,000 \mathrm{mg} / \mathrm{L}$ or $7,000,000 \mu \mathrm{g} / \mathrm{L}$, the numerical value is the same as for concentrations in parts per million or parts per billion, respectively. Milliequivalents per liter are units expressing concentrations that are chemically equivalent in terms of atomic or molecular weight and electrical charge.

Specific conductance is given in microsiemens per centimeter at 25 degrees Celsius $(\mu \mathrm{S} / \mathrm{cm}$ at $\left.25^{\circ} \mathrm{C}\right)$.

Concentrations of dissolved gases are reported in cubic centimeters of gas at standard temperature and pressure per gram of water (ccSTP/g). Tritium concentration is reported in tritium units (TU) where one TU is equivalent to one molecule of tritiated water $\left({ }^{3} \mathrm{H}^{1} \mathrm{HO}\right)$ in 1018 molecules of non-tritiated water ('H2O) or 3.2 picocuries per liter. Carbon-14 activity is reported as percent modern carbon (pMC). Stable-isotope ratios are reported as delta $(\delta)$ values, which are parts per thousand or permil (\%) difference(s) from a standard.

\section{Abbreviations}

$\begin{array}{ll}{ }^{129} \mathrm{Xe} & \text { xenon-129 } \\ { }^{14} \mathrm{C} & \text { carbon-14 or radioactive isotope of carbon } \\ { }^{18} \mathrm{O} & \text { oxygen-18 } \\ { }^{20} \mathrm{Ne} & \text { neon-20 } \\ { }^{2} \mathrm{H} & \text { deuterium } \\ { }^{3} \mathrm{H} & \text { tritium } \\ { }^{3} \mathrm{He} & \text { helium-3 } \\ { }^{3} \mathrm{He} & \text { helium-3 from tritium decay } \\ { }_{\text {trit }}^{40} \mathrm{Ar} & \text { argon-40 } \\ { }^{4} \mathrm{He} & \text { helium-4 } \\ { }^{4} \mathrm{He} & \text { terrigenic helium-4 (uranium/thorium-series decay) } \\ { }^{84} \mathrm{Kr} & \text { krypton-84 } \\ \text { BARCAS } & \text { Basin and Range carbonate-rock aquifer system }\end{array}$


BP

$\mathrm{CO}_{2}$

EPA

ET

ET

$\mathrm{ET}_{\mathrm{g}}$

EVI

GBCAAS

GDA

GIS

$\mathrm{He}$

HGU

$\mathrm{H}_{\max }$

$\mathrm{H}_{\mathrm{r}}$

ID

LCAU

LEDAPS

MCL

MODIS

MSAVI

NAIP

NCCU

NDVI

NGT

$\mathrm{NGT}_{\text {avg }}$

$\mathrm{NGT}_{\text {max }}$

$\mathrm{NGT}_{\text {min }}$

PRISM

$\mathrm{R}$

$r^{2}$

$\mathrm{R}_{\mathrm{a}}$

RASA

RAWS

TDS

TM before present

carbon dioxide

Environmental Protection Agency

evapotranspiration

actual evapotranspiration

groundwater evapotranspiration

Enhanced Vegetation Index

Great Basin carbonate and alluvial aquifer study

groundwater discharge area

Geographic Information System

helium

hydrogeologic unit

maximum recharge altitude

recharge altitude

identification

lower carbonate aquifer unit

Landsat Ecosystem Disturbance Adaptive Processing System

maximum contaminant level

Moderate Resolution Imaging Spectroradiometer

Modified Soil-Adjusted Vegetation Index

National Agriculture Imagery Program

non-carbonate confining unit

Normalized Difference Vegetation Index

noble-gas recharge temperature

average noble-gas temperature

maximum noble-gas temperature

minimum noble-gas recharge temperature

Parameter-Elevation Regressions on Independent Slopes Model

$3 \mathrm{He} / 4 \mathrm{He}$ ratio in groundwater

coefficients of determination

atmospheric $3 \mathrm{He} / 4 \mathrm{He}$ ratio

Regional Aquifer-System Analysis

Remote Automated Weather Stations

total dissolved solids

Thematic Mapper 


$\begin{array}{ll}\text { UCAU } & \text { upper carbonate aquifer unit } \\ \text { USCU } & \text { upper siliciclastic confining unit } \\ \text { USGS } & \text { U.S. Geological Survey } \\ \text { WRS2 } & \text { world reference system 2 } \\ \delta^{13} \mathrm{C} & \text { relative measured stable isotope of carbon } \\ \delta^{18} \mathrm{O} & \text { relative measured stable isotope of oxygen } \\ \delta^{2} \mathrm{H} \text { or } \delta \mathrm{D} & \text { relative measured stable isotope of hydrogen }\end{array}$




\title{
Hydrogeologic and Geochemical Characterization of Groundwater Resources in Pine and Wah Wah Valleys, Iron, Beaver, and Millard Counties, Utah
}

\author{
By Philip M. Gardner, Thomas M. Marston, Susan G. Buto, and Lynette E. Brooks
}

\section{Abstract}

Pine and Wah Wah Valleys are neighboring structural basins that encompass about 1,330 square miles in Beaver, Iron, and Millard Counties in Utah, approximately 50 miles northwest of Cedar City, Utah, and 50 miles southeast of Baker, Nevada. Perennial streamflow is limited and only exists in higher-altitude reaches of small mountain streams in both basins. Groundwater is in unconsolidated basin-fill aquifers and bedrock mountain aquifers. Groundwater in Pine and Wah Wah Valleys is being targeted for large-scale groundwater extraction and export to provide municipal supply to the growing population in Iron County, Utah. Concern about declining groundwater levels and spring flows from proposed groundwater withdrawals has increased interest in an improved understanding of the groundwater system. Previous studies have indicated that an average of 28,000 acre-feet per year of recharge occurs mostly as infiltration of precipitation in high-altitude regions in the two basins. Groundwater discharge in the mountain hydrologic systems was estimated to average 8,500 acre-feet per year and is assumed to be consumed before subsequently recharging the valley basinfill aquifers. Subsurface groundwater outflow moves from basin-fill aquifers in Pine and Wah Wah Valleys northward to adjacent regional basins and was estimated to average 19,500 acre-feet per year.

An updated water-level map for the basin-fill aquifers in Pine and Wah Wah Valleys indicates that groundwater moves northward along the lengths of both valleys toward adjacent basins. Measured depths to water range from about 210 to 750 feet below land surface in Wah Wah Valley, and from about 300 to 620 feet below land surface in Pine Valley. Long-term water levels at seven wells completed in the basin-fill aquifers of Pine and Wah Wah Valleys with records spanning more than 40 years are generally stable with observed fluctuations of less than 5 feet. Observed discharge from two springs monitored between 2013 and 2016 also is generally stable.
Groundwater leaving Pine and Wah Wah Valleys through the subsurface moves northward, converges with regional groundwater flow, and discharges by evapotranspiration at regional groundwater discharge areas, likely Tule Valley, Utah. In this study, basin-scale groundwater discharge was estimated by (1) mapping the groundwater discharge areas in each valley; (2) evaluating the 2005-11 summer multispectral satellite images against the Basin and Range carbonate-rock aquifer system study evapotranspiration measurements to select scenes broadly representative of average conditions in the study area and partitioning the groundwater discharge areas into evapotranspiration units using the selected satellite images and field reconnaissance; and (3) scaling evapotranspiration to the evapotranspiration units using evapotranspiration-rate estimates from several studies in the Great Basin. The resulting updated estimates of average annual groundwater evapotranspiration in the Tule Valley and Sevier Lake groundwater discharge areas were 35,000 and 10,500 acre-feet per year, respectively, with a likely uncertainty of plus or minus 35 percent.

Groundwater samples from 13 sites in Pine Valley and 11 sites in Wah Wah Valley were analyzed for major ions and nutrients, to characterize geochemistry and water quality. Groundwater samples also were analyzed for the stable isotopes of oxygen, hydrogen, and carbon, the radioactive isotopes of carbon and hydrogen, and dissolved noble gases including helium-3, helium-4, neon, argon, krypton, and xenon. Groundwater sampling sites included 12 wells and 12 springs. Carbon-14 and tritium/helium groundwater age dating indicate that groundwater in the basin-fill aquifers is typically thousands to tens of thousands of years older than groundwater in the shallow mountain aquifers.

Dissolved-solids concentrations are lower and noble-gas temperatures are warmer in the valley wells compared to almost all groundwater sampled from wells and springs in the surrounding mountains. These results indicate a hydraulic discontinuity between the mountain and valley aquifers throughout much of the study area, and that much of the valley recharge is not derived from direct infiltration of precipitation in the mountains. 


\section{Introduction}

Pine and Wah Wah Valleys are rural valleys approximately 50 miles (mi) northwest of Cedar City, Utah, and approximately $50 \mathrm{mi}$ southeast of Baker and Great Basin National Park, Nevada. Pine and Wah Wah Valleys are neighboring hydrologic/structural basins that encompass about 1,330 square miles $\left(\mathrm{mi}^{2}\right)$ in Beaver, Millard, and Iron Counties, Utah, and are east of Snake and Hamlin Valleys and south of Tule Valley and the Sevier Desert in western Utah (fig. 1). Both basins are bounded by surfacewater drainage divides on all sides, but they are not closed groundwater basins. Groundwater resources aside from Wah Wah Springs are largely undeveloped with a limited number of wells completed in the basin-fill aquifer in both valleys. Groundwater levels in the valleys are generally hundreds of feet below land surface and neither basin contains areas in the valley lowlands where groundwater is shallow enough to be discharged by evapotranspiration (ET).

Total recharge for both basins has been estimated to be 28,000 acre-feet per year (acre-ft/yr) occurring as infiltration of precipitation that falls mostly on the mountains surrounding both valleys (Stephens, 1974, 1976). Groundwater discharge in Pine and Wah Wah Valleys occurs almost entirely as discharge to springs, small streams, and as ET in the surrounding mountains. Previous studies have hypothesized that groundwater that does not discharge in the surrounding mountains enters the adjacent basin-fill aquifers near the mountain front in both valleys and is subsequently discharged through the subsurface to other adjacent basins to the north (Stephens, 1974, 1976). Perennial streamflow is limited and only exists in high-altitude reaches of small mountain streams in both basins. Streamflow events that occur in ephemeral valley washes from intense rainfall are short in duration and represent an insignificant source of surface-water.

Recent proposals by the Central Iron County Water Conservancy District (CICWCD) to develop groundwater resources in and around Pine and Wah Wah Valleys have focused attention on the need for a better understanding of the groundwater resources in these valleys. The groundwater resources that sustain streams, springs, small wetlands, and local agricultural uses in these valleys are poorly understood. At the time of this study, minimal groundwater development had occurred in Pine and Wah Wah Valleys and anthropogenic impacts to the groundwater system had been negligible. Waterresource managers from the Utah Department of Natural Resources, CICWCD, and the Bureau of Land Management require additional information and an improved hydrogeologic conceptual model to make informed decisions about future water-resource development in the area.

\section{Purpose and Scope}

The purpose of this study was to assess groundwater resources in Pine and Wah Wah Valleys through improving the general understanding of groundwater presence, sources, and movement. Specifically, this study evaluated the hydrologic conditions at the time of this report, including groundwater levels, recharge to the groundwater system, and discharge from springs and evapotranspiration. This information has been combined with other data, including geochemical groundwater tracers, to determine sources of water to groundwater discharge areas, evaluate groundwater flow paths, and assess interbasin (subsurface) flow between adjacent valleys. Results from this study have been utilized to create an updated conceptual model of the groundwater flow system and then integrated into the existing updated Great Basin carbonate and alluvial aquifer study (GBCAAS) numerical groundwater flow model of the area, thus providing improved tools for use in future management decisions (Brooks, 2017a).

\section{Previous Investigations}

Initial hydrologic reconnaissance studies of Pine and Wah Wah Valleys were completed by Stephens $(1974,1976)$ and the results of these studies were incorporated in a hydrologic reconnaissance of the southern Great Salt Lake Desert (Gates and Kruer, 1981). Several more recent and ongoing regional investigations in east-central Nevada and western Utah have helped improve the understanding of groundwater resources in the eastern Great Basin, including Pine and Wah Wah Valleys. A Regional Aquifer-System Analysis (RASA) of the Great Basin was conducted by the U.S. Geological Survey (USGS) in Nevada and Utah, and included Pine and Wah Wah Valleys. This analysis, summarized by Harrill and Prudic (1998) provided a regional base of information including a description of the regional Great Basin aquifer systems (sources and rates of recharge and discharge), estimates of hydraulic properties of the groundwater flow system, and an understanding of the functioning of multi-basin flow.

Pine and Wah Wah Valleys are included within the boundaries of the GBCAAS and the Snake Valley numerical groundwater flow models (Brooks and others, 2014; Masbruch and others, 2014). Sensitivity analyses indicated that calibration of both numerical models is highly sensitive to recharge rates and aquifer hydraulic properties in and directly north of Pine and Wah Wah Valleys. Variations in these model parameters have substantial impacts on model-simulated water levels and discharge rates in surrounding valleys, illustrating the importance of refining these estimates. This is the same geographic area that Stephens (1974) was referring to when he stated that "the paucity of data on both subsurface lithology and water levels [in the areas north of Pine and Wah Wah Valleys] precludes a reliable estimate of volume or direction of groundwater flow." 

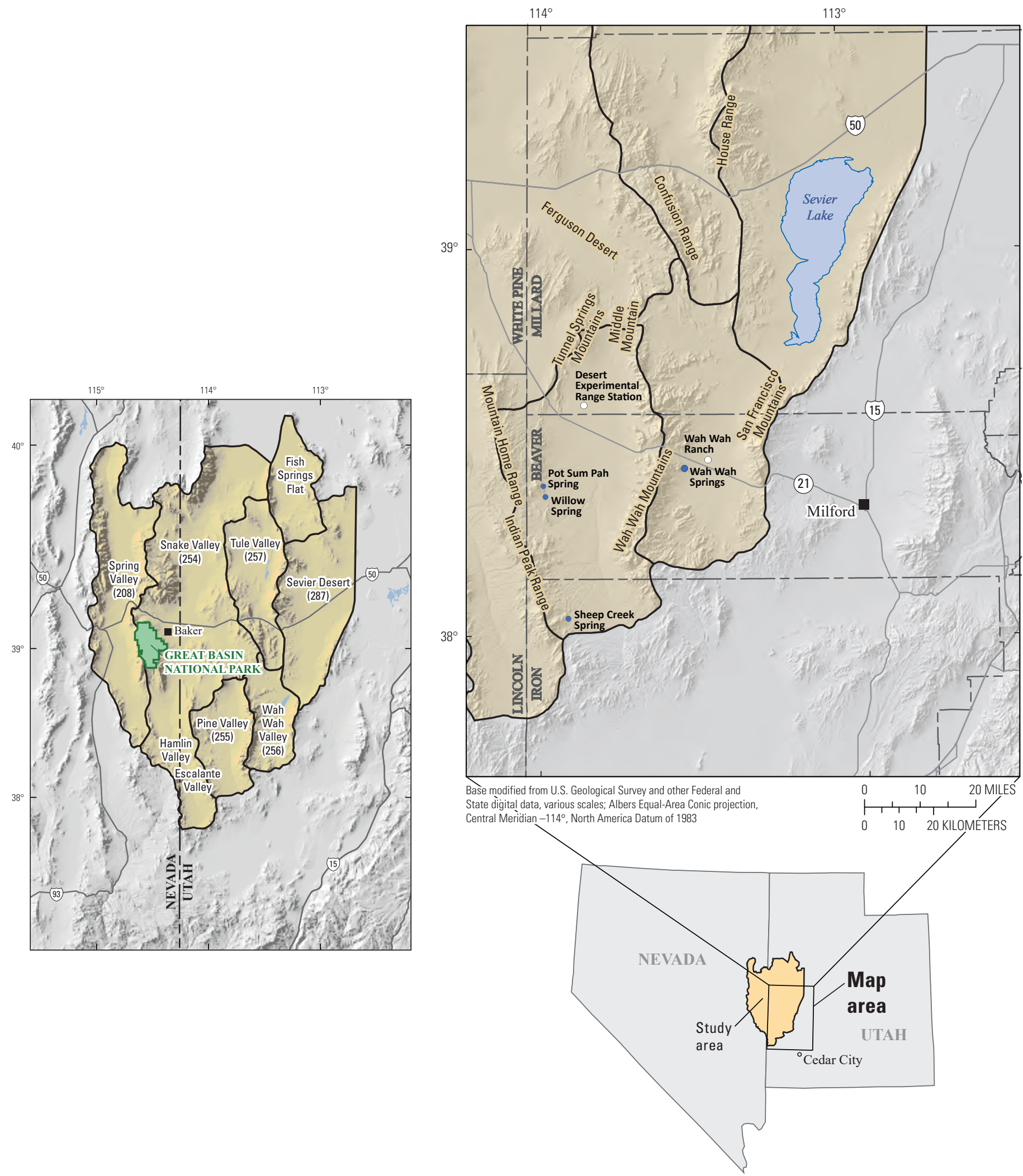

Figure 1. Location of Pine and Wah Wah Valleys, Iron, Beaver, and Millard Counties, Utah. 
Results from initial investigations by Stephens (1974, 1976) indicated that a total of about 28,000 acre- $\mathrm{ft} / \mathrm{yr}$ of water recharges Pine and Wah Wah Valleys in the form of infiltrating precipitation. The recharge estimates were made using a modified version of the Maxey-Eakin method described by Hood and Waddell (1968). Stephens reported that about 7,000 acre-ft/yr and 1,500 acre-ft/yr of groundwater is discharged in the Pine and Wah Wah Valley drainage basins respectively, at mountain locations as evapotranspiration and groundwater seepage to streams and springs that is subsequently consumed by evaporation, with a much smaller amount being pumped from existing wells. Stephens also reported that the groundwater discharged in the surrounding mountains contributed insignificant amounts of subsequent recharge to the valley-fill aquifers. In the studies conducted by Stephens, the groundwater flow systems were assumed to be in steady-state. Thus, the combined discharge from the basinfill aquifers in Pine and Wah Wah Valleys was assumed to be the difference between the Maxey-Eakin estimated recharge and the reported consumptive discharge from mountain areas, together equaling 19,500 acre-ft/yr (Stephens, 1974, 1976).

\section{Approach and Methods}

The approach for investigation in this study included the following components (1) taking measurements of water levels at 63 new and previous identified well sites and spring discharge at 11 previously identified spring sites to produce a water-level map for Pine and Wah Wah Valleys; (2) utilizing water-level data and spring discharge data obtained during this study for comparison to historical data to establish a baseline dataset for groundwater conditions before significant development; (3) updating groundwaterevapotranspiration $\left(\mathrm{ET}_{\mathrm{g}}\right.$ ) estimates in the hydrologically connected Tule Valley basin and Sevier Lake area to the north of the study area to improve the GBCAAS numerical model calibration for regional groundwater discharge related to the study area; (4) obtaining water samples from wells and springs for geochemical analyses of major-ions and selected trace elements, isotopic age-dating tracers, and noble gas recharge temperatures to improve the conceptual model of the groundwater system; and (5) providing updated groundwater budget estimates for Pine and Wah Wah Valleys using the GBCAAS v.3.0 numerical model (Brooks, 2017a, b) for comparison to previous estimates.

\section{Data Collection Methods}

Field parameters were measured with a multi-parameter sonde placed in a flow-through chamber connected to a discharge line near the well head for each of the 12 sampled wells, and in the 12 sampled springs at a submerged depth nearest the source of spring discharge.

Laboratory water-quality analyses of groundwater from Pine and Wah Wah Valleys included major and trace dissolved inorganic and organic constituents, tritium $\left({ }^{3} \mathrm{H}\right)$, carbon-14, stable isotopes of hydrogen and oxygen in water, and dissolved noble gases. The major inorganic ions included calcium, magnesium, sodium, potassium, bicarbonate, sulfate, chloride, and nitrate. Trace ions included fluoride, bromide, iron, manganese, arsenic, molybdenum, nitrite, ammonia, and orthophosphate. Dissolved noble gases included helium-3 $\left({ }^{3} \mathrm{He}\right)$, helium-4 $\left({ }^{4} \mathrm{He}\right)$, neon-20 $\left({ }^{20} \mathrm{Ne}\right)$, argon-40 $\left({ }^{40} \mathrm{Ar}\right)$, krypton-84 $\left({ }^{84} \mathrm{Kr}\right)$, and xenon-129 $\left({ }^{129} \mathrm{Xe}\right)$.

Water-chemistry samples were collected from wells by using either installed submersible or top-mounted pumps or by temporary pumps used during pump tests. Before waterchemistry sample collection from monitoring wells, water was purged from each well until field parameters stabilized and a minimum of three casing volumes were removed. After purging each well, water was pumped into samples bottles and filtered as necessary. Water-chemistry samples were collected from springs by portable peristaltic pump as grab samples.

Samples for major and trace ions were filtered with 0.45 -micron disposable filters and collected in clean polyethylene bottles according to procedures described by Wilde and Radtke (1998); samples for ion analysis were preserved with 7.7-normal nitric acid. Tritium samples were collected in 500 milliliter $(\mathrm{ml})$ polyethylene bottles with polyseal caps without head space. Stable isotopes of hydrogen and oxygen were collected in $60-\mathrm{ml}$ bottles with polyseal caps without head space. Carbon-14 samples were collected in 1-liter (L) glass bottles, according to procedures described by the USGS National Water Quality Laboratory. Noble gases were collected with diffusion sampler methods described by Sheldon (2002) and Gardner and Solomon (2009), and with copper tube methods described by Stute and Schlosser (2000).

Inorganic and organic chemical analyses (major and trace ions) were analyzed by the USGS at the National Water Quality Laboratory in Denver, Colorado. Stable isotopes of hydrogen and oxygen in water were analyzed by the USGS at the Stable Isotope Laboratory in Reston, Virginia. Tritium and noble gases were analyzed by the University of Utah's Dissolved Gas Laboratory using quadrupole and sector-field mass spectrometers; tritium concentrations were determined with the in-growth method (Clarke and others, 1976). Carbon-14 samples were analyzed by the Woods Hole Oceanographic Institution McLean Laboratory. 


\section{Physical Characteristics of the Study Area}

\section{Pine Valley}

Pine Valley is a topographically closed basin bounded by the Wah Wah Mountains to the east, and the Needle Mountains to the west (fig. 1). Collectively, the Mountain Home Range and the Indian Peak Range are known as the Needle Mountains due to their jagged nature. The northern end of the basin is divided from Ferguson Desert by a broad low divide connecting the northern end of the Wah Wah Mountains with isolated Middle Mountain, Tunnel Spring Mountains, and the Needle Mountains. The southern end of the basin is divided from Escalante Valley to the south by a low divide between the Wah Wah Mountains and the Indian Peak Range in the Needle Mountains.

Most streams in Pine Valley are ephemeral. Sheep and Indian Creeks, in the southeastern Needle Mountains, and Pine Grove Creek, in the west central Wah Wah Mountains, are perennial in higher elevation reaches. These streams are usually ephemeral lower in their reaches as they approach alluvial deposits in the valley. Pine Valley Wash extends from the southern divide of the basin, north toward the playa in the lowest-altitude region in the valley.

Most of the known springs in Pine Valley are in the Needle Mountains and are associated with volcanic lithologies, with historical discharge rates for any given spring less than 60 gallons per minute (gal/min; Stephens, 1976, table 7). All known springs discharge at altitudes above 6,200 feet (ft). Pot Sum Pah, Willow, and Sheep Creek Springs were selected for monitoring during the course of this study.

\section{Wah Wah Valley}

Wah Wah Valley is a closed surface-water basin bounded by the Wah Wah Mountains to the west, the House and Confusion Ranges to the north, and the San Francisco Mountains to the east (fig. 1). The northeastern end of the basin is separated from the Sevier Desert by a broad low divide between the House Range and the San Francisco Mountains.

The are no perennial streams in Wah Wah Valley; all washes and streams are intermittent or ephemeral. Large stream channels and washes in the valley include Wah Wah Wash, Grover Wash, Willow Creek, Quartz Creek, and Frisco
Wash. Streamflow has been historically observed in these channels during large high-intensity precipitation events, but typically does not persist for great distances owing to streambed seepage. Wah Wah Wash is the predominant wash that drains into the Wah Wah Valley playa at the north end of the basin.

Wah Wah Springs is the most well-known spring in the valley. The Springs are actually a complex of springs on the west side of the valley just south of Utah State Highway 21 that discharge from carbonate lithology at the base of the Wah Wah Mountains. Water from the spring has been used historically in early mining operations in the late 1800 s associated with the San Francisco Mountains and the now abandoned town of Newhouse. At the time of this report, it was the sole source of water to a small agricultural ranch in the center of the valley. Stephens (1974) estimated the discharge of Wah Wah Springs at about $500 \mathrm{gal} / \mathrm{min}$. Wah Wah Springs was selected for long-term monitoring as part of this study.

\section{Population and Land Use}

Pine and Wah Wah Valleys are very limited in their number of inhabitants. There are no named cities or towns in either valley. There is one agricultural establishment, Wah Wah Ranch, which is approximately one-half mile north of Utah State Highway 21 near the center of Wah Wah Valley. Primary land use in both basins consists of livestock grazing and open recreational activities on federally owned lands.

\section{Climate and Precipitation}

The climate of Pine and Wah Wah Valleys is arid and is characterized by moderate to little precipitation, large daily temperature changes, moderately cold winters, and warm dry summers. The average annual precipitation (1981-2010) estimated from Parameter-Elevation Regressions on Independent Slopes Model (PRISM) data for Pine and Wah Wah Valleys and most of the surrounding mountains ranges from about 8 to 16 inches (in.; Daly and others, 2008). Average annual precipitation reaches 24 in. in the highest altitudes of the Indian Peak Range of southwest Pine Valley (fig. 2). Total PRISM-estimated average annual precipitation for this period is 510,000 acre-feet for Pine Valley and 320,000 acre-feet for Wah Wah Valley. 


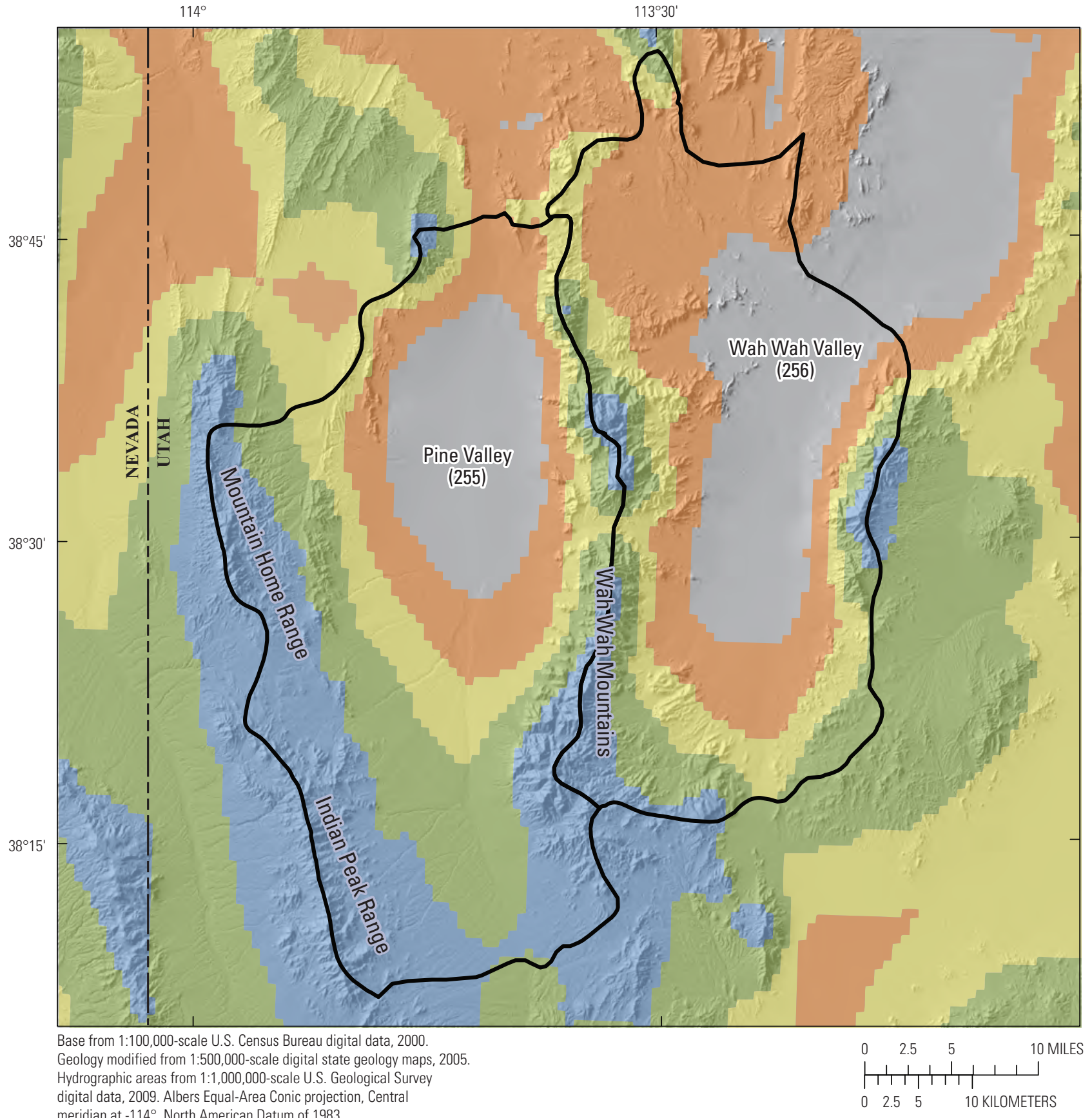

meridian at $-114^{\circ}$, North American Datum of 1983

EXPLANATION

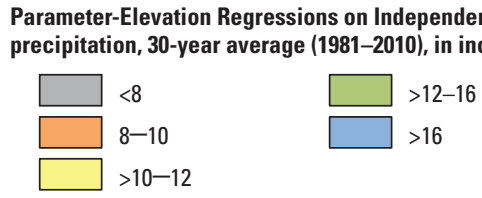

Figure 2. Average annual precipitation in Pine and Wah Wah Valleys, Utah, 1981-2010. 
Two weather stations are in Pine and Wah Wah Valleys (fig. 1). The Desert Experimental Range station (NOAA COOP station 422116) is in Pine Valley at an altitude of 5,300 $\mathrm{ft}$ and has a historical period of record from January 1950 to September 1984. The Wah Wah Ranch station (NOAA COOP station 429152) is in Wah Wah Valley at an altitude of 4,900 ft and has a historical period of record from August 1955 to June 2008. Average monthly precipitation for each of the valleys for the period of record for both stations is shown in figure 3 . The average monthly precipitation in Pine Valley during the period of record ranges from about $0.3 \mathrm{in}$. during the winter months of November, December, January, and February to about 0.9 in. during July and August. The average annual air temperature in Pine Valley was 9.5 degrees Celsius $\left({ }^{\circ} \mathrm{C}\right)$ for the 34-year period of record from 1950 to 1984. The average monthly precipitation in Wah Wah Valley during the period of record was similar in magnitude and trend to the precipitation in Pine Valley and ranged from about 0.4 in. during the winter months of November, December, January, and February to about 1 in. during August. The average annual air temperature in Wah Wah Valley was $10.8^{\circ} \mathrm{C}$ for the 53 -year period of record from 1955 to 2008 .

\section{Geology}

Pine and Wah Wah Valleys are part of a series of eastward-tilted fault blocks that are bounded on each side by normal faults associated with basin and range tectonic extension in the Great Basin physiographic region. Faulting extends along the lengths of each of the mountain ranges that divide the basins, including the San Francisco Mountains, Wah Wah Mountains, and the Needle Mountains. Lithologies in both valleys range in age from Precambrian to Holocene.

The Precambrian through Paleozoic units consist mainly of quartzites and carbonates with lesser amounts of shales, siltstones, and sandstones. They are the dominant lithologies that crop out on the western slopes of the San Francisco Mountains, Wah Wah Mountains, House Range, Confusion Range, and the northern portions of the Needle Mountains. They are generally low in primary permeability, but they can have moderate-to-high secondary permeability where fractured or solution derived openings are abundant.

The Cenozoic volcanic units that dominate the southern portion of Pine Valley as various tuffs and ignimbrites throughout the study area are the result of eruptive events associated with the Indian Peak Caldera Complex (Best and others, 2013). The southern portion of Pine Valley was the site of at least two calderas in the Indian Peak Caldera Complex: the Pine Valley caldera and the Mackleprang caldera. Best and others (2013) also infer that the southern parts of Pine Valley could have been the location of the caldera that produced the Marsden Tuff. Multiple eruptive events during the Cenozoic era have deposited thick sequences of tuffs and ignimbrites that could have backfilled earlier calderas.

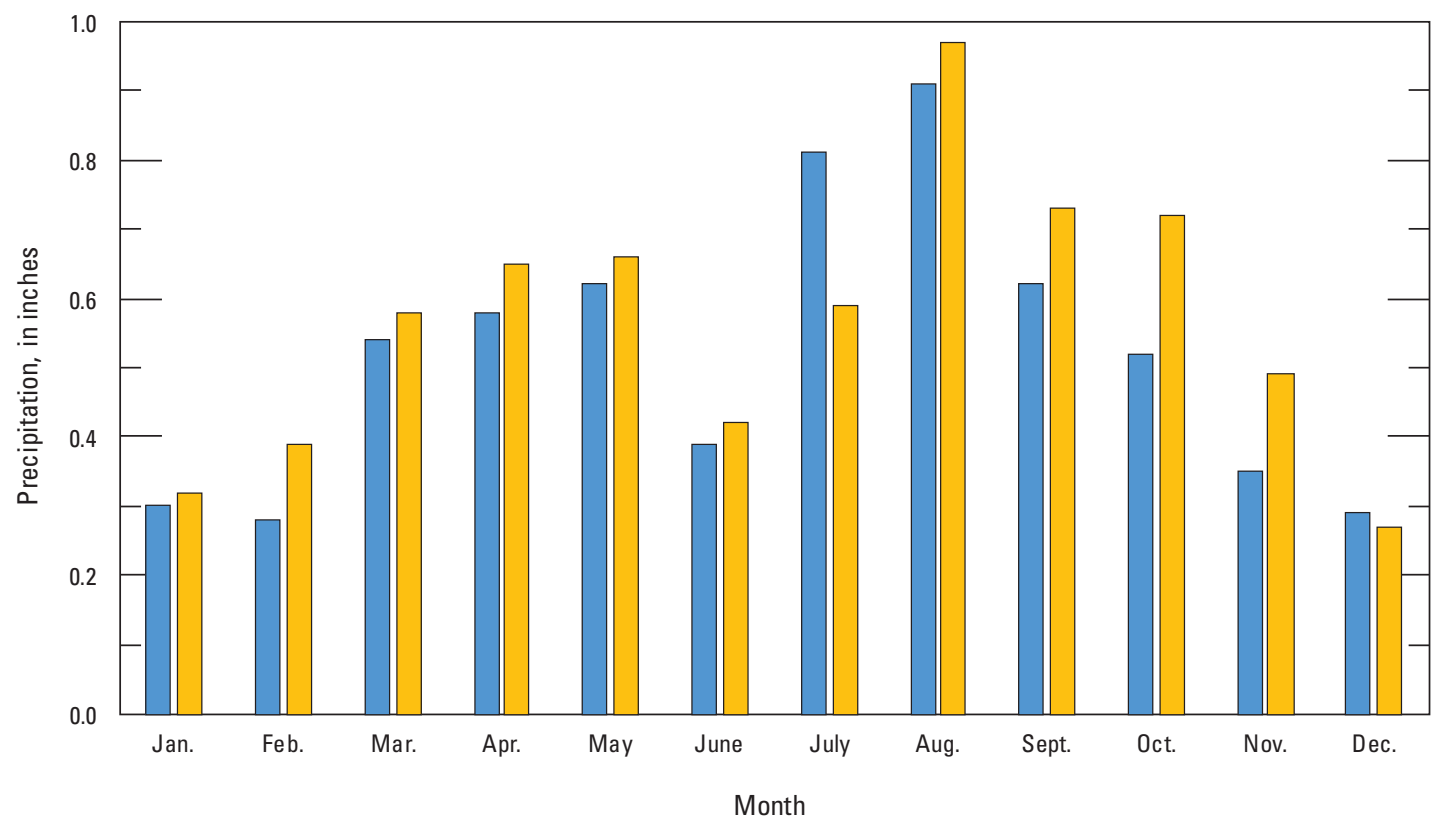

EXPLANATION

Pine Valley, DESERT EXP RANGE (422116), January 1950-September 1984

Wah Wah Valley, WAH WAH RCH (429152), August 1955-June 2008

Figure 3. Average monthly precipitation for weather stations in Pine and Wah Wah Valleys, Utah. 


\section{Groundwater Hydrology}

The groundwater system in the study area consists of water in unconsolidated deposits in the basins and water in consolidated rock (bedrock) underlying the basins and in the adjacent mountain blocks. The consolidated-rock and basin-fill aquifers have a limited connection hydraulically, with most of the recharge occurring in the consolidated-rock mountain blocks discharging in gaining streams and springs in the mountain areas. The hydrologic characteristics of the basin-fill aquifer water in Pine and Wah Wah Valleys indicate that the local mountain recharge zones do not contribute a significant amount of recharge to the basin-fill aquifers. The data and interpretation that yield this observation are addressed in the "Discussion" section below.

In the study area, groundwater divides do not coincide with surface-water divides in some areas. For example, Stephens (1976) observed that part of the Wah Wah Valley groundwater system was directly supported by recharge that occurred in the Pine Valley drainage basin. Specifically, quartzite and carbonate lithologies that crop out on the west side of the Wah Wah Mountains that dip to the east likely transfer recharge as seepage in Pine Valley to Wah Wah Valley through fractured bedrock. Stephens (1974) observed that the unique geologic structure of the carbonate lithology in the Wah Wah Mountains provides the recharge source and mode of transmission for water that discharges from Wah Wah Springs. Further investigation and results included in this study reinforce this observation.

\section{Hydrogeology}

As part of the GBCAAS study, a three-dimensional hydrogeologic framework of the eastern Great Basin was constructed (Cederberg and others, 2011; Sweetkind and others, 2011). The GBCAAS study area is inclusive of Pine and Wah Wah Valleys; therefore, this same hydrogeologic framework was used in this study. The framework was constructed using data from a variety of sources, including geologic maps and cross sections, drill-hole data, geophysical models, and stratigraphic surfaces created for other threedimensional hydrogeologic frameworks within the GBCAAS study area. The framework was developed using a $1 \mathrm{mi}^{2}$ gridcell size.

In the hydrogeologic framework developed for the GBCAAS study, the consolidated pre-Cenozoic-age rocks, Cenozoic-age sediments, and igneous rocks in the study area were subdivided into nine hydrogeologic units (HGUs; Sweetkind and others, 2011). An HGU has considerable lateral extent and reasonably distinct physical characteristics that could be used to infer the capacity of a sediment or rock to transmit water. The definition of HGUs is important in conceptualizing the hydrogeologic system and construction of a geologic framework for describing the groundwater flow system.

Of the nine HGUs defined in the hydrogeologic framework developed for the GBCAAS, five are in this study area (fig. 4). The HGUs in this study area are (1) a non-carbonate confining unit (NCCU) representing lowto-moderate permeability Precambrian-age siliciclastic formations as well as intrusive igneous rocks that are locally exposed in mountain ranges, and underlie parts of the study area; (2) a lower carbonate aquifer unit (LCAU) representing a thick succession of predominantly high-tomoderate permeability Cambrian through Devonian-age carbonate rocks that are locally exposed in the mountain ranges, and present beneath most of the valleys within the study area; (3) an upper siliciclastic confining unit (USCU) representing low-permeability Mississippian-age siliciclastic rocks, predominantly shales, that are limited in extent within the study area; (4) an upper carbonate aquifer unit (UCAU) representing a thick succession of low-to-high permeability Pennsylvanian- and Permian-age carbonate rocks that are locally exposed in the mountain ranges and exist beneath some of the valleys within the study area; and (5) a volcanic unit (VU) representing large volumes of low-to-high permeability Cenozoic-age volcanic rocks that are locally exposed in the mountain ranges and exist beneath some of the valleys in the study area. In this study the Cenozoic valley-fill sediments are referred to as the basin-fill aquifer.

\section{Aquifer Properties}

Aquifer properties describe the ability of a groundwater system to transmit and store water. The distribution of these properties in the study area is variable and depends on the depositional environment of sediments in the basin-fill aquifer and confining units, and on the degree of structural deformation, fracturing, and chemical dissolution in the bedrock aquifers and confining units. Aquifer properties can be estimated with aquifer tests and specific-capacity tests by pumping groundwater from a well and monitoring the water-level changes in the pumped well and in nearby observation wells. Aquifer tests and specific-capacity data are commonly used to estimate values of transmissivity, hydraulic conductivity, and storativity or the storage coefficient. Transmissivity and hydraulic conductivity describe the ease with which water can move through the pore space in an aquifer. More specifically, hydraulic conductivity is the volume of water flowing through a unit cross-sectional area of an aquifer under a unit hydraulic gradient in a given amount of time; and transmissivity is the volume of water flowing through a cross-sectional area that is one-unit wide multiplied by the aquifer thickness in a given amount of time. The storage coefficient is the volume of water released from storage per unit decline in hydraulic head (water level) in the aquifer (Freeze and Cherry, 1979). 


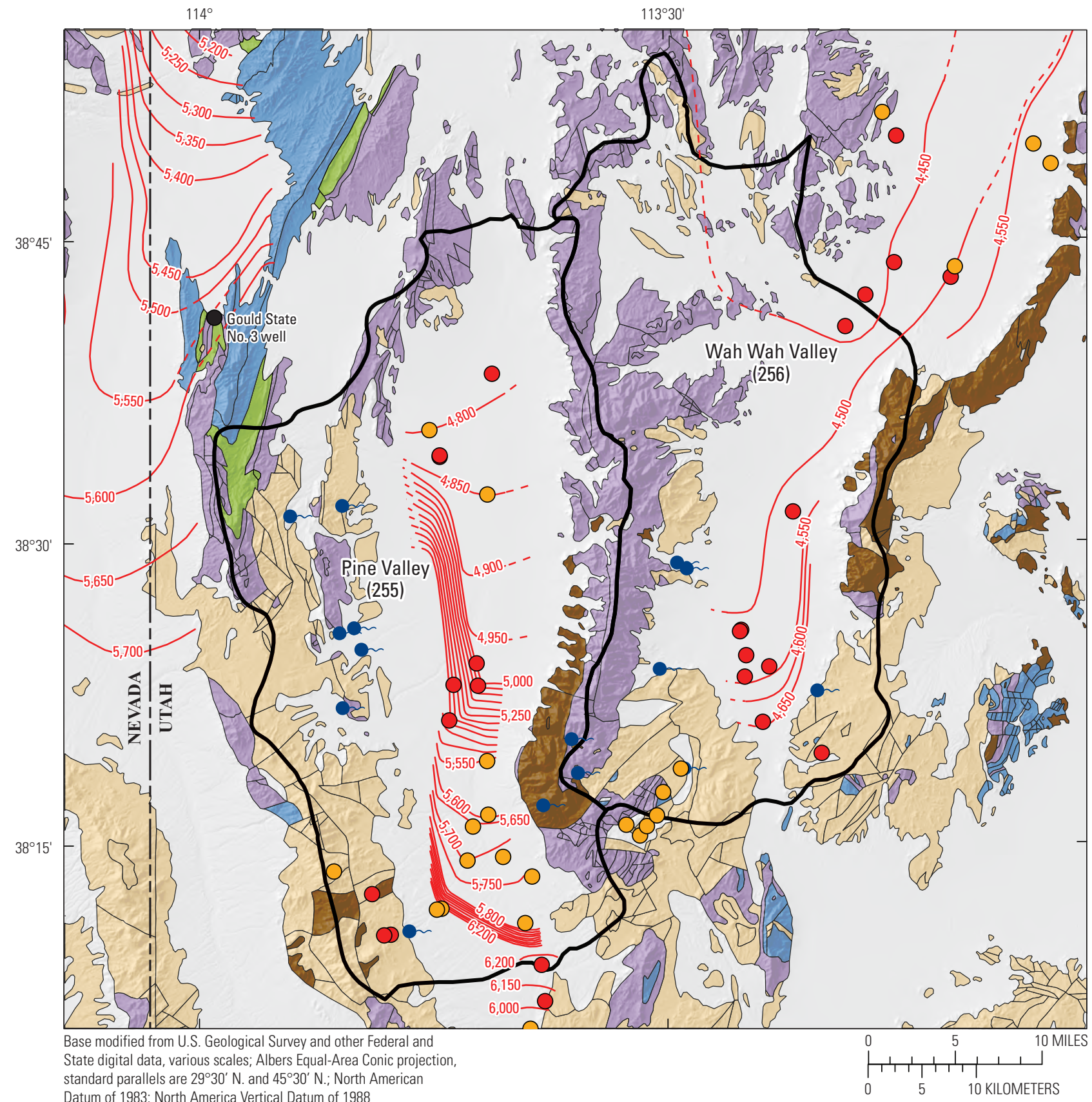

EXPLANATION
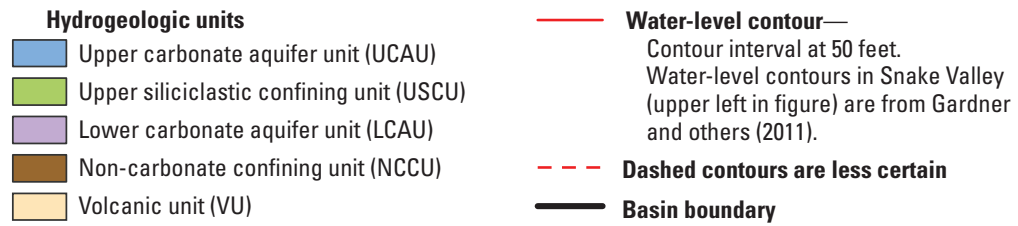

Water level measured by U.S. Geological Survey during this study

Water level reported on driller's log or by other entity

Spring

Locations and identifier of well or spring with time-series of water levels or discharge measurements shown in figures 6 and 7.

Figure 4. Surficial extent of hydrogeologic units and water-level (potentiometric) contours indicating the general direction of groundwater movement. 


\section{Basin Fill}

Aquifer properties for the basin-fill aquifers in Pine and Wah Wah Valleys were determined from 10 single-well pump tests where a value for specific capacity was calculated. Transmissivity values were estimated from specific-capacity values by considering a range of storage coefficients representing unconfined conditions $(0.075)$ to confined conditions (0.001). The transmissivity calculated for the basinfill aquifer in Pine and Wah Wah Valleys mostly ranged from about 400 to 9,000 square feet per day ( $\mathrm{ft}^{2} / \mathrm{d}$; table 1, fig. 5). One well, CICWCD \#25, which is in the far southern portion of Pine Valley, yielded a transmissivity range of $20-30 \mathrm{ft}^{2} / \mathrm{d}$. The driller's log indicates that the aquifer consists of sands and gravels at this location, but low yields could be the results of lower permeability volcanic lithologies and their weathering products in the area. Another well, CICWCD \#11, which is in the center of the southern portion of Pine Valley, yielded a transmissivity range of 94,000-120,000 $\mathrm{ft}^{2} / \mathrm{d}$. The driller's log indicates a higher percentage and frequency of gravel/cobble layers, which can produce high values of transmissivity when saturated. The reported drawdown during the pumping test at CICWCD \#11 after pumping at $189 \mathrm{gal} / \mathrm{min}$ for 24 hours was $0.5 \mathrm{ft}$. This value is significantly less than any other test in the area and could be erroneous.

\section{Bedrock}

Aquifer properties for the bedrock in Pine Valley were determined from two single-well pump tests at wells CICWCD \#7 and \#18 where a value for specific capacity was calculated. Transmissivity values were estimated from specific capacity values using the Cooper and Jacob (1946) solution for flow to a well in a confined aquifer by considering a range of storage coefficients representing unconfined conditions $(0.075)$ and confined conditions (0.001). It is unclear from the driller's logs what rock type the wells were screened in. The transmissivity calculated from these two wells ranged from about 10 to $580 \mathrm{ft}^{2} / \mathrm{d}$ (table 1). Rock type, fracture density, and degree of fracture interconnection influence the value of transmissivity when considering fractured bedrock aquifers.

\section{Presence and Movement of Groundwater}

Sources of groundwater in Pine and Wah Wah Valleys are in the basin-fill and bedrock aquifers under confined and unconfined conditions. In the basin-fill aquifer, unconfined conditions generally exist in the upper portions of alluvial fans, with confined conditions in areas where fine-grained sediment is interlayered with more course gravels and sands, found near the centers of the valleys. Previous investigations (Stephens, 1974, 1976) have indicated that many of the bedrock aquifers in the mountains could be perched relative to the basin-fill aquifers. The connection between the bedrock aquifers and the basin-fill aquifers in the subsurface is not well understood.

A water-level map for the basin-fill aquifer in Pine and Wah Wah Valleys was constructed using water-level measurements taken at wells and considering springs in the low-altitude areas of the surrounding mountain regions totaling 63 sites (fig. 4; table A-1). Pine and Wah Wah Valleys are closed surface-water basins, but groundwater levels indicate that groundwater moves northward in both valleys toward adjacent basins.

Depth to water is generally deep in the basin-fill aquifers toward the center of the valleys. In Wah Wah Valley, waterlevel depths in wells (C-24-13)34ccb-1 and (C-28-14)26bbd-1 show a range from about 210 to $750 \mathrm{ft}$ below land surface. In Pine Valley, depths to water are slightly shallower than in Wah Wah Valley with observed depths of about $620 \mathrm{ft}$ at well (C-28-17) $1 \mathrm{dbb}-1$ and $300 \mathrm{ft}$ at (C-25-16)18bdd-1 (fig. 4; table A-1). Shallower water levels found in volcanic lithologies were observed at higher altitudes along the margins of both valleys as well as in local mountain bedrock aquifers.

Steep hydraulic gradients are inferred by water levels observed in Pine Valley. The areas of steepest hydraulic gradient are in the southern portion of Pine Valley and along the western margin of the valley in the central portion (fig. 4). It is possible that these areas represent the boundary between sediment types that make up the basin-fill aquifer in Pine Valley. The southern and western sides of Pine Valley likely contain fine-grained sediment that is a weathering product of the volcanic lithologies that dominates the Needle Mountains and southern portions of the Wah Wah Mountains, whereas the eastern sides of Pine Valley likely contain more course-grained sediment derived from quartzites that are found on the western slopes of the Wah Wah Mountains. 
Table 1. Aquifer properties of basin-fill and bedrock aquifers from selected driller's logs in Pine and Wah Wah Valleys, Utah.

[Horizontal coordinate information is referenced to the North American Datum of 1983 (NAD 83). Abbreviaitons: USGS, U.S. Geological Survey; mm/dd/yyyy, month/day/year; -, no data; NR, not reported; $\mathrm{ND}$, not determined]

\begin{tabular}{|c|c|c|c|c|c|c|c|c|c|c|c|c|}
\hline Well name & USGS site name & $\begin{array}{l}\text { Latitude } \\
\text { (decimal } \\
\text { degrees) }\end{array}$ & $\begin{array}{c}\text { Longitude } \\
\text { (decimal } \\
\text { degrees) }\end{array}$ & $\begin{array}{c}\text { Date of test } \\
\text { (mm/dd/ } \\
\text { yyyy) }\end{array}$ & $\begin{array}{c}\text { Well } \\
\text { diameter } \\
\text { (inches) }\end{array}$ & $\begin{array}{l}\text { Screened } \\
\text { interval of } \\
\text { well } \\
\text { (feet } \\
\text { below land } \\
\text { surface) }\end{array}$ & $\begin{array}{c}\text { Bedrock } \\
\text { or basin- } \\
\text { fill }\end{array}$ & $\begin{array}{l}\text { Pumping } \\
\text { rate } \\
\text { (gallons } \\
\text { per } \\
\text { minute) }\end{array}$ & $\begin{array}{c}\text { Duration } \\
\text { (hours) }\end{array}$ & $\begin{array}{l}\text { Drawdown } \\
\text { (feet) }\end{array}$ & $\begin{array}{c}\text { Specific } \\
\text { capacity } \\
\text { (gallons } \\
\text { per minute } \\
\text { per foot of } \\
\text { drawdown) }\end{array}$ & $\begin{array}{c}\text { Transmissivity } \\
\text { (feet squared } \\
\text { per day') }\end{array}$ \\
\hline CICWCD \#6 & - & 38.275539 & -113.691082 & $11 / 04 / 2016$ & 6 & $600-1,000$ & Basin-fill & 168 & $\mathrm{NR}^{2}$ & 69 & 2.4 & $400-580$ \\
\hline CICWCD \#7 & - & 38.197012 & -113.746362 & $02 / 02 / 2017$ & 6 & $250-1,000$ & Bedrock & 198 & 30 & 82 & 2.4 & $410-580$ \\
\hline CICWCD \#8 & - & 38.240485 & -113.675263 & $10 / 31 / 2016$ & 6 & $550-1,000$ & Basin-fill & 168 & $\mathrm{NR}^{2}$ & 58 & 2.9 & $490-690$ \\
\hline CICWCD \#11 & - & 38.265714 & -113.707401 & $11 / 09 / 2016$ & 6 & $500-1,000$ & Basin-fill & 189 & $\mathrm{NR}^{2}$ & ${ }^{3} 0.5$ & 380 & ${ }^{3} 94,000-120,000$ \\
\hline CICWCD \#18 & - & 38.319833 & -113.692094 & $11 / 02 / 2016$ & 6 & $440-880$ & Bedrock & 4 & $\mathrm{NR}^{2}$ & 57 & 0.1 & $7-13$ \\
\hline CICWCD \#12 & - & 38.237688 & -113.713291 & $01 / 24 / 2017$ & 6 & $550-1,000$ & Basin-fill & 168 & 29 & 24 & 7.0 & $1,300-1,800$ \\
\hline CICWCD \#25 & - & 38.185634 & -113.651885 & $10 / 16 / 2016$ & 6 & $700-1,000$ & Basin-fill & 10 & $\mathrm{NR}^{2}$ & 61 & 0.2 & $20-30$ \\
\hline $\begin{array}{l}{ }^{4} \text { Phelps } \\
\text { Dodge \#19 }\end{array}$ & (C-28-17)11 cca-1 & 38.383015 & -113.727751 & $06 / 12 / 1978$ & 12 & ND-970 & Basin-fill & 402 & 44 & 139.5 & 2.9 & $450-650$ \\
\hline $\begin{array}{l}{ }^{4} \text { Phelps } \\
\text { Dodge \#27 }\end{array}$ & (C-28-17)22dda-1 & 38.353571 & -113.732473 & 06/12/1978 & 8 & ND-2006 & Basin-fill & 503 & 44 & 35.2 & 14.3 & $2,800-3,800$ \\
\hline Wah Wah \#1 & (C-28-14)11abb-1 & 38.397184 & -113.389411 & $12 / 13 / 1974$ & 12 & $680-1,475$ & $\begin{array}{l}\text { Basin-fill / } \\
\text { bedrock }\end{array}$ & 1,353 & 28 & 113 & 12 & $2,100-2,900$ \\
\hline Wah Wah \#26 & (C-28-14)10cbd-1 & 38.388806 & -113.415500 & 06/04/1975 & 16 & $800-970$ & $\begin{array}{l}\text { Basin-fill / } \\
\text { bedrock }\end{array}$ & 1,281 & 72 & 73 & 18 & $3,200-4,500$ \\
\hline Wah Wah \#29 & $(\mathrm{C}-28-14) 3 \mathrm{bcd}-1$ & 38.406500 & -113.414083 & $02 / 14 / 1975$ & 12 & $700-1,480$ & $\begin{array}{l}\text { Basin-fill / } \\
\text { bedrock }\end{array}$ & 1,401 & 48 & 44 & 32 & $6,300-8,500$ \\
\hline
\end{tabular}

${ }^{1}$ Range of transmissivity $(\mathrm{T})$ based on a range of storage coefficients representing unconfined (0.075) and confined (0.001) aquifer conditions.

${ }^{2}$ Assumed to be 24 hours if not reported.

${ }^{3}$ Actual drawdown is reported as zero, which results in unrealistic transmissivity (T). This result should be considered suspect.

${ }^{4}$ Results from the drawdown associated with the highest pumping rate and longest duration during the step test reported by Phelps Dodge Corp. 


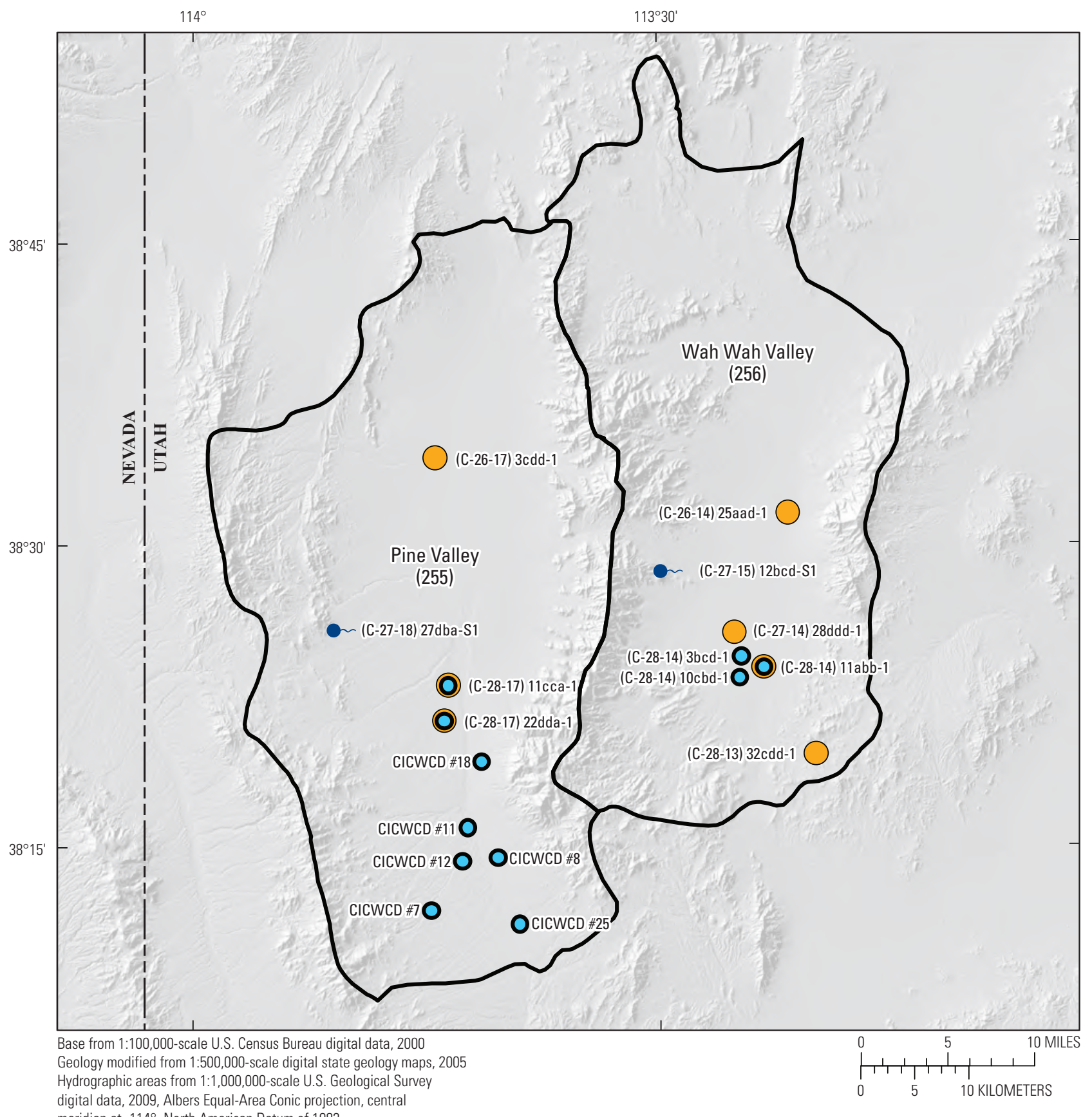

EXPLANATION

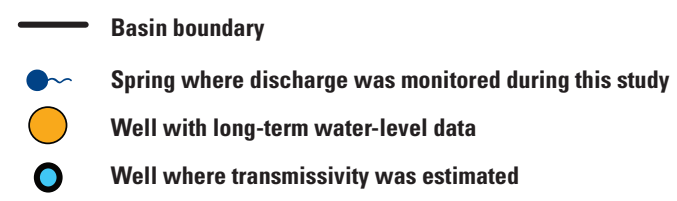

Figure 5. The locations of selected wells and springs with time-series records of water levels or discharge and wells where aquifer transmissivity was estimated in Pine and Wah Wah Valleys, Utah. 


\section{Water-Level and Spring-Discharge Trends}

Water levels in wells and discharge from springs fluctuate in response to imbalances between groundwater recharge and discharge. Water levels rise and spring discharge increases when recharge exceeds discharge for a period of time and decline when the opposite occurs. Variations in recharge and discharge in Pine and Wah Wah Valleys are driven predominantly by natural processes, such as annual variability in precipitation and groundwater withdrawals from wells, and by anthropogenic (human-induced) processes, which have been historically negligible. Long-term water-level and spring discharge fluctuations in Pine and Wah Wah Valleys are presented for seven wells and two springs shown on figure 5 . All water-level and discharge data are available through the USGS National Water Information System database (https://waterdata.usgs.gov/nwis). Six of the wells with longterm water-level data are completed in the deep basin-fill aquifers of Pine and Wah Wah Valleys; the remaining well, (C-28-13)32cdd-1 is completed in the volcanic-rock aquifer in the mountains of southeastern Wah Wah Valley. Both springs where discharge was measured are in bedrock aquifers in the mountains. In most of the seven wells, water levels were generally stable for the period of record represented at each site (fig. 6). The total water-level change at any of the sites that were observed was not greater than $5 \mathrm{ft}$. In well (C-28-13)32cdd-1, in the southeastern part of Wah Wah Valley, a steady decline in water level was observed from 2008 to 2017, which could represent response to drier than normal conditions that have occurred during this time. Conversely, in well (C-28-17)22dda-1, on the western side of central Pine Valley, a steady increase in water level was observed from 2013 to 2017, which could represent a delayed response through a large unsaturated zone to a period of above average recharge in the region. In both springs, discharge remained stable from 2013 to 2016 (fig. 7). Discharge from Pot Sum Pah Spring was relatively constant at about $15 \mathrm{gal} / \mathrm{min}$ from early 2013 to early 2016 . There was only a slight decrease in discharge from Wah Wah Springs from about 2.3 cubic feet per second ( $\left.\mathrm{ft}^{3} / \mathrm{s}\right)$ in early 2013 to about $2.2 \mathrm{ft}^{3} / \mathrm{s}$ in early 2016 . This decrease could have been the result of drier than normal conditions that occurred during the period of record. The discharge measured at Wah Wah Springs was approximately twice that reported by Stephens (1974). 

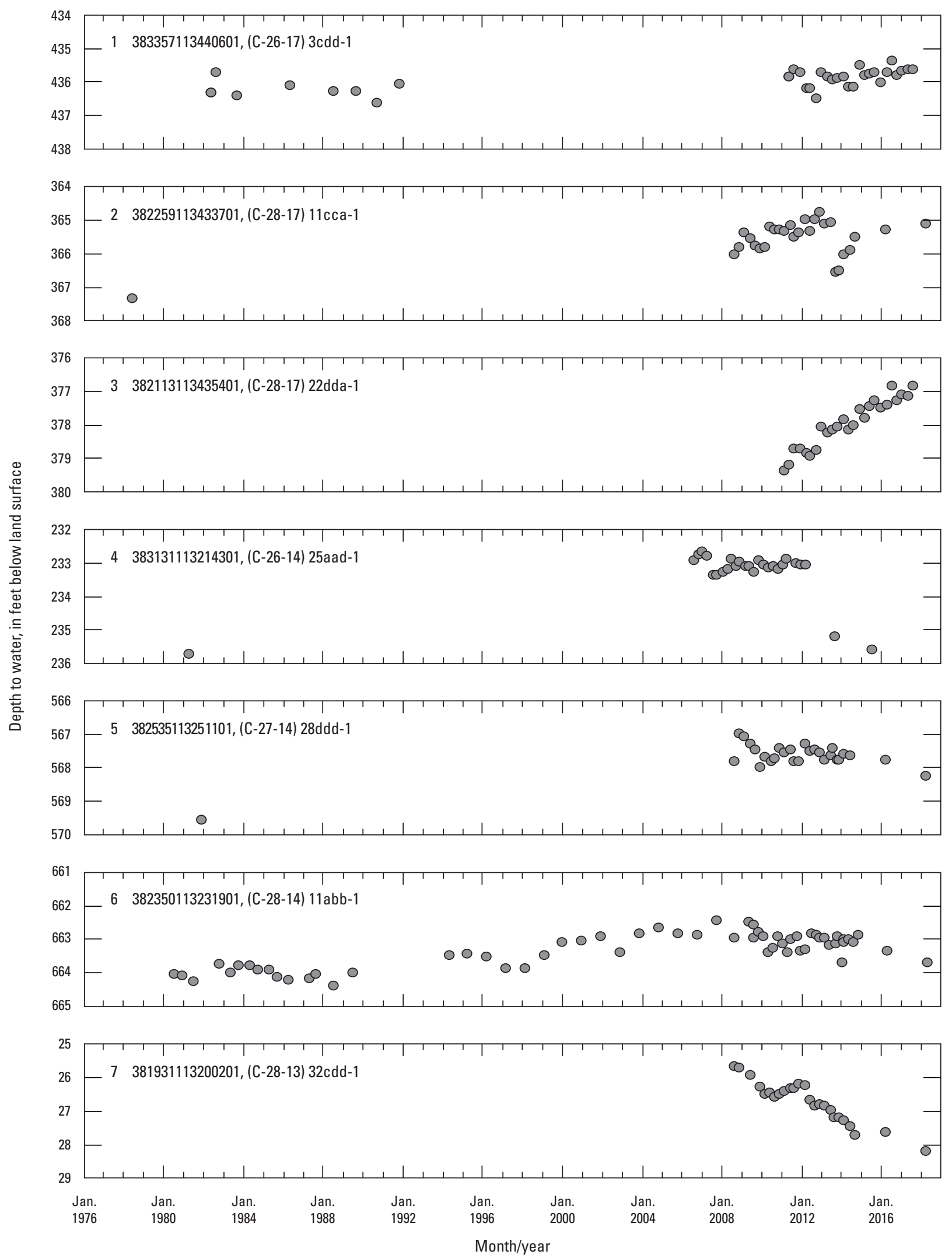

Figure 6. Long-term water-level fluctuations in selected wells in Pine and Wah Wah Valleys, Utah. 

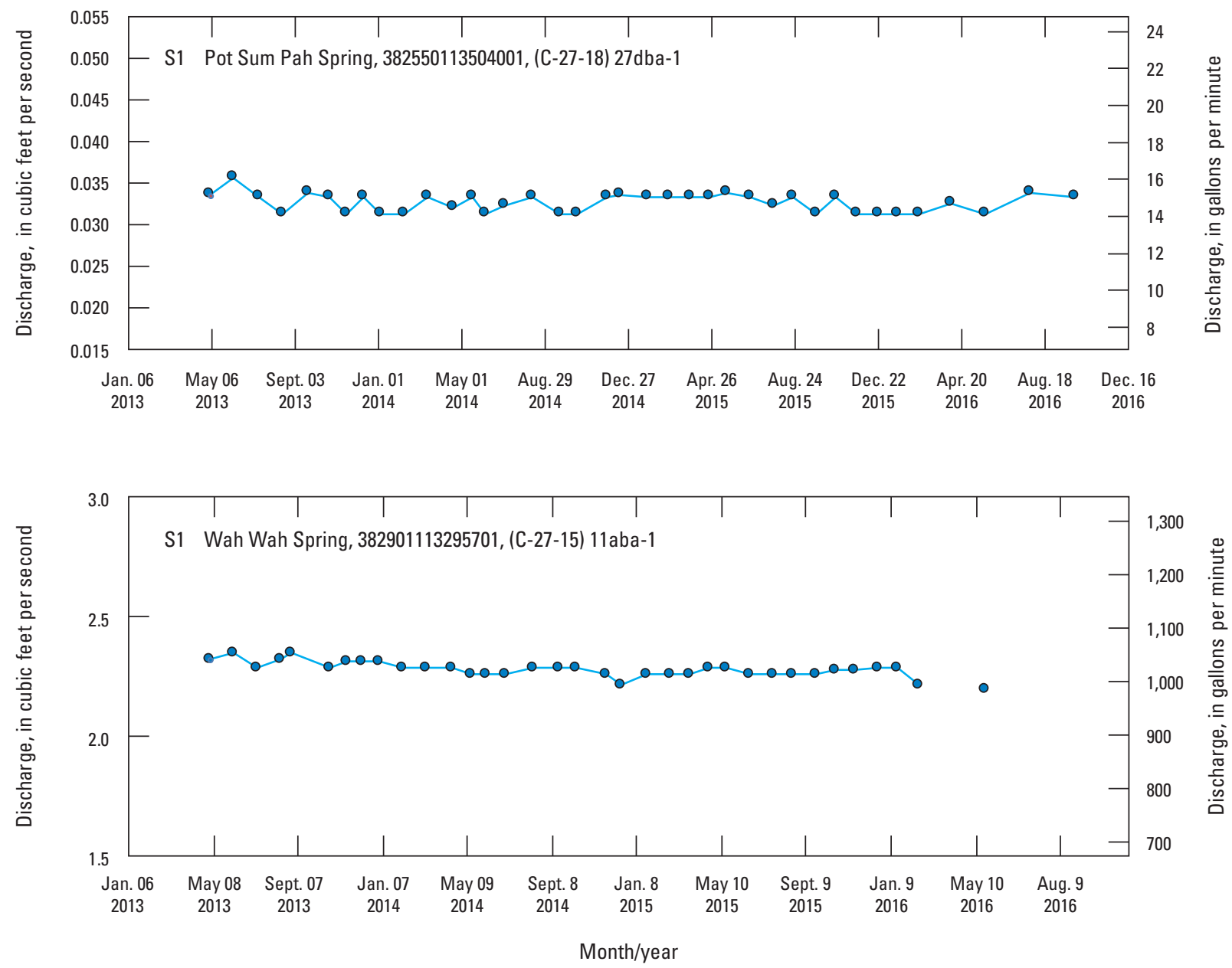

Figure 7. Discharge at springs in the mountains of the Pine and Wah Wah Valleys drainage basins, Utah.

\section{Regional Evapotranspiration Occurring North of the Study Area}

Groundwater discharge through ET is the largest natural outflow component of groundwater in most western Utah valleys; it consists of transpiration by phreatophytic vegetation, which uses shallow groundwater as a primary water source and evaporation from bare soil, Groundwater discharge from ET occurs in topographically low areas referred to as groundwater discharge areas (GDAs) where groundwater is at or near the surface. Pine and Wah Wah Valleys are unique when compared to surrounding valleys in western Utah in that no groundwater discharge by ET occurs from the basin-fill aquifers owing to the deep water tables in these valleys. Rather, nearly all discharge from the basinfill aquifers occurs by subsurface outflow to other basins. Groundwater leaving Pine and Wah Wah Valleys through the subsurface moves northward, converges with regional groundwater flow from the east and possibly the west, and discharges by $\mathrm{ET}_{\mathrm{g}}$ at regional GDAs, likely in Tule Valley or in the southern Sevier Desert near Sevier Lake (Gardner and others, 2011). Previous estimates of groundwater discharge by ET for these areas were based on reconnaissance-level study and could have had uncertainties as high as plus or minus 100 percent. Updated $\mathrm{ET}_{\mathrm{g}}$ estimates for these two areas were made to better constrain Pine and Wah Wah Valley groundwater budgets using the groundwater model of the Great Basin carbonate and alluvial aquifer system Version 3.0 (Brooks, 2017a,b).

The total volume of water discharged by ET can be calculated as the product of the rate at which water is transferred from the land to the atmosphere (ET rate) and the area of the vegetation, open water, and soils that transfer this water. Groundwater ET, the fraction of total ET made up of groundwater, is calculated by subtracting precipitation from the total ET. The resulting updated estimates of average annual $\mathrm{ET}_{\mathrm{g}}$ in the Tule Valley and Sevier Lake GDAs were 35,000 and 10,500 acre-ft/yr, respectively, with a likely uncertainty of plus or minus \pm 35 percent (Michael Moreo, U.S. Geological Survey, written comm., 2012). 
Evapotranspiration rates were estimated from eddycovariance measurements collected at six sites in nearby valleys west of the study area. The six eddy-covariance sites were installed in Spring, Snake, and White River Valleys from September 2005 through 2006 as part of the Basin and Range carbonate-rock aquifer system (BARCAS) study (Moreo and others, 2007). Data from the sites, that are in a range of phreatophytic vegetation assemblages, helped to select Landsat satellite imagery used to estimate groundwater discharge in Tule Valley and the area surrounding Sevier Lake. Groundwater discharge was estimated based on vegetation characteristics identified in the satellite imagery and during field mapping of the extent of the GDA in both valleys. In this study, basin-scale groundwater discharge was estimated by (1) mapping the GDA in each valley; (2) evaluating 2005-11 summer multispectral satellite images against BARCAS study ET measurements to identify images broadly representative of average conditions in the study area, and partitioning the GDA into ET units using the selected satellite images and field reconnaissance; and (3) scaling ET to the ET units using ET rate estimates from several studies in the Great Basin.

\section{Scaling from Site Measurement to Basin- Scale Estimates}

\section{Delineation of Groundwater Discharge Areas}

The GDAs for this study consist of discrete boundaries in Tule Valley and part of Sevier Desert surrounding Sevier Lake (fig. 8). The GDA boundaries represent the margin between areas where xerophytic shrubs that obtain water from precipitation and shallow soil moisture are predominant outside the boundary, and a mix of xerophytic and phreatophytic shrubs are inside the boundary. The GDAs were mapped using techniques similar to those used in studies throughout Nevada and eastern Utah (Nichols, 2000; Laczniak and others, 2001; Smith and others, 2007; Allander and others, 2009; Garcia and others, 2014). National Agriculture Imagery Program (NAIP) imagery from 2011 (U.S. Department of Agriculture, 2012), a digital elevation model (U.S. Geological Survey, 2017), and water-level data were used in conjunction with field visits to map the GDA at approximately 1:24,000-scale. During field visits, accessible roads were followed and the point at which xerophytic vegetation transitions to phreatophytic vegetation was marked on a digital map using a Global Positioning System unit connected to a computer running Geographic Information System (GIS) software. Photographs and notes were taken to document plant and soil conditions present at the marked location. Points, photographs, and notes also were used to document plant communities inside the mapped GDA boundaries where accessible. The final GDA boundary in each valley was digitized into a GIS feature class using the field mapped points, NAIP, and satellite imagery to help interpolate the location of the boundary between mapped field locations in areas where field reconnaissance was not possible because of limited access. Playa boundaries were mapped using a combination of field points, satellite imagery, and 2011 NAIP imagery. The final GDA boundary encompasses 81,659 acres in Tule Valley with 30,390 acres of that area covered by playa. The Tule Valley GDA is characterized by large areas of phreatophytic vegetation adjacent to the playa on the west and south and a thin band bordering the playa on the east. The Tule Valley playa is underlain by fresh water, hosts springs discharging fresh water, and is covered by very sparse phreatophytic vegetation. The Sevier Lake GDA encloses approximately 143,239 acres, of which 121,392 acres are lakebed playa. The Sevier Lake GDA is characterized by a narrow band of phreatophytic vegetation along the east, west, and southern margins of the playa and a more extensive expanse of phreatophytes following the course of the Sevier River northeast from its mouth. The Sevier Lake playa is underlain by dense brine and its salt-encrusted surface is devoid of vegetation. These are characteristics of playas where it has been shown that groundwater discharge by evapotranspiration is negligible (Jackson and others, 2018). The 121,392-acre Sevier Lake playa is excluded from the Sevier Lake GDA by assuming an ET rate equal to 0 feet per year ( $\mathrm{ft} / \mathrm{yr}$ ). It had previously been assumed that the generally dry lakebed of Sevier Lake was a groundwater

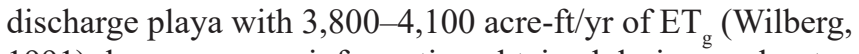
1991); however, new information obtained during exploratory drilling and groundwater sampling, by $\mathrm{CH} 2 \mathrm{M}$ Hill and Peak Minerals during 2012 and 2013, illustrates that this is not the case (Stephen Hill, Peak Minerals, written commun., 2014). Sediment beneath the playa consists of thick (greater than $500 \mathrm{ft}$ ) terminal lake deposits with extremely low permeability (Hydraulic conductivity of less than 0.001 foot per day; $\mathrm{ft} / \mathrm{d}$ ), which is below approximately the upper $100 \mathrm{ft}$ and limits groundwater movement. Groundwater samples from wells screened directly beneath the playa or playa edges have high total dissolved solids (TDS) concentrations (ranging from 33,000 to greater than 200,000 milligrams per liter; $\mathrm{mg} / \mathrm{L}$ ) and stable-isotope values of oxygen $\left(\delta^{18} \mathrm{O}\right)$ and hydrogen $\left(\delta^{2} \mathrm{H}\right.$ or $\left.\delta^{2} \mathrm{D}\right)$ that clearly indicate extensive evaporative enrichment (fig. 9). In contrast, low TDS groundwater samples from wells surrounding the Sevier Lake playa have meteoric stable-isotope values indicating that they have not undergone evaporation. The stable-isotope data indicate that the high TDS waters beneath the Sevier Lake playa must have spent considerable time undergoing evaporation on the paleosurface of this terminal lakebed. This pattern is the opposite of what would be observed if regional fresh groundwater was moving upward to discharge by ET or bare soil evaporation from the Sevier Lake playa. 


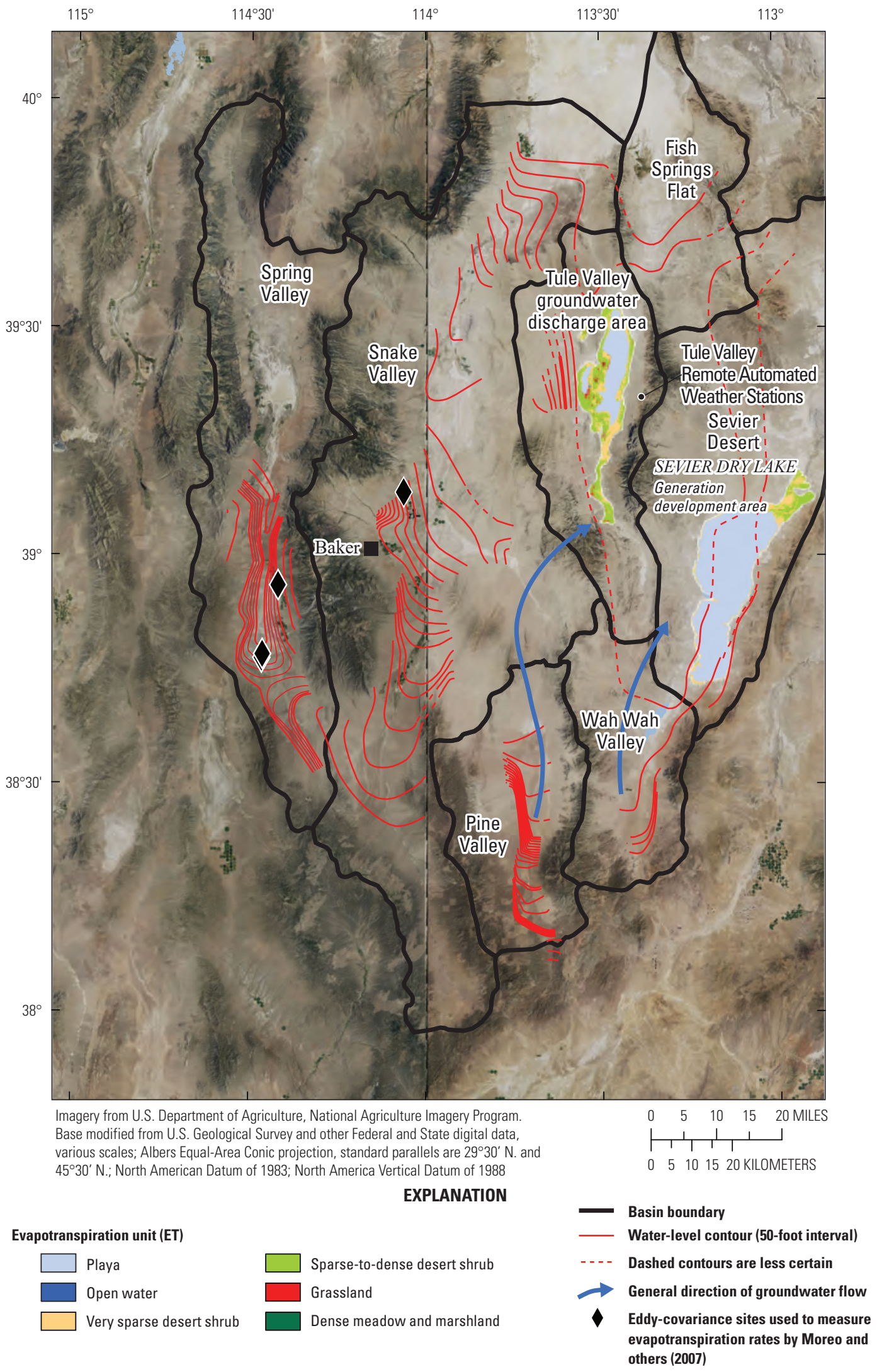

Figure 8. Location and classification of evapotranspiration units used in the calculation of average annual evapotranspiration of groundwater in the Tule Valley and Sevier Lake groundwater discharge areas, Utah. 


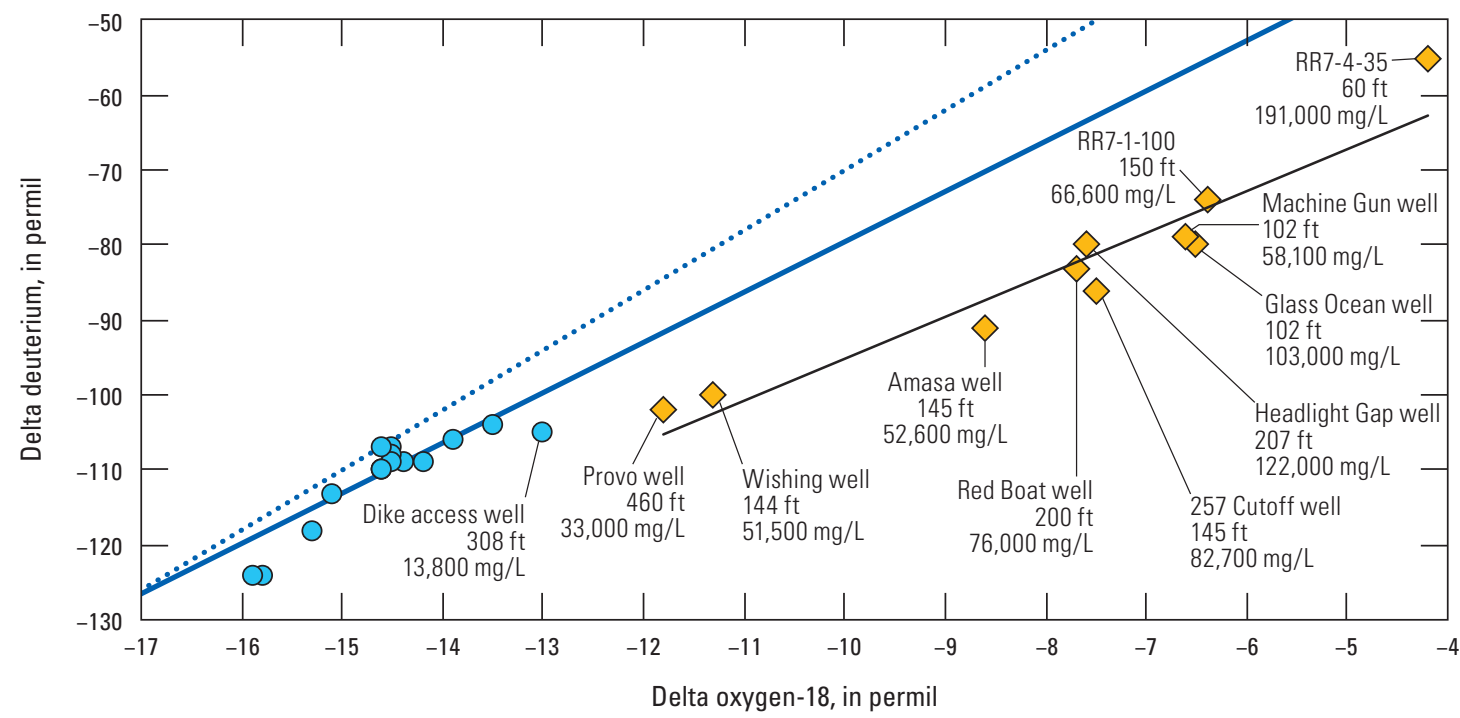

EXPLANATION

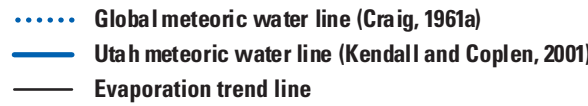

Groundwater sample - text indicates well name (top), well depth in feet (middle), and dissolved solids concentration in milligrams per liter (bottom)

Figure 9. Stable isotopes of freshwater and brine showing evaporatively enriched waters in saturated sediments below the Sevier Lake playa, Utah.

\section{Evapotranspiration Units and Estimates of Groundwater Evapotranspiration}

Many studies have shown that the amount and rate of water lost to the atmosphere by ET in groundwater discharge areas varies with vegetation type and cover, depth to water, and soil characteristics (Laczniak and others, 1999, 2001, 2008; Nichols, 2000). Satellite imagery in combination with field mapping is often used to identify and group areas of similar vegetation and soil characteristics assuming that ET generally increases with increasing vegetation density and soil moisture (Laczniak and others, 2001; Moreo and others, 2007; Smith and others, 2007; Garcia and others, 2014; Berger and others, 2016). These areal groupings are referred to as ET units and are assumed to consist of areas with similar ET discharge rates (fig. 8).

Evapotranspiration rates for the study area were estimated on the basis of ET rate ranges from Welch and others (2007) supplemented with information gathered from more recent studies in Nevada (Garcia and others, 2014; Berger and others, 2016), net irrigation water requirements , and actual $\mathrm{ET}\left(\mathrm{ET}_{\mathrm{a}}\right)$ rates for alfalfa and open water, respectively, in Snake Valley, Nevada (Huntington and Allen, 2010). Ranges of $\mathrm{ET}_{\mathrm{a}}$ rate estimates for ET units mapped in the Tule Valley and Sevier Lake GDAs during field work were assembled and used to estimate ET by subtracting 2006-09 mean annual precipitation $(0.46 \mathrm{ft} / \mathrm{yr})$ measured at the Tule Valley Remote Automated Weather Station (RAWS; table 2; fig. 8).
Table 2. Ranges of average annual actual evapotranspiration rates ( $E T_{a}$ ) for evapotranspiration units (ET units) in the Tule Valley and Sevier Lake groundwater discharge areas, Utah.

[ft, feet]

\begin{tabular}{|c|c|c|}
\hline \multirow{2}{*}{ Discharge area } & \multicolumn{2}{|c|}{$\begin{array}{l}\text { Range of average annual } \mathrm{ET}_{\mathrm{a}} \text { rates } \\
(\mathrm{ft})\end{array}$} \\
\hline & Low & High \\
\hline Playa $^{1}$ & 0.05 & 0.05 \\
\hline Very sparse desert shrub² & 0.84 & 0.84 \\
\hline Sparse to dense desert shrub ${ }^{3}$ & 0.84 & 1.80 \\
\hline Grassland $^{4}$ & 1.60 & 2.70 \\
\hline Dense meadow and marshland ${ }^{5}$ & 2.70 & 3.00 \\
\hline Open water ${ }^{6}$ & 4.70 & 4.70 \\
\hline
\end{tabular}

${ }^{1}$ Based on playa rates from Garcia and others, 2014.

${ }^{2}$ Based on the mean annual evapotranspiration rate at the Spring Valley site (SPV1; Moreo and others, 2007) and the Kobeh Valley site 1 (Berger and others, 2016).

${ }^{3}$ Based on the range between the very sparse desert shrub rate and the upper end of the dense desert shrubland (Welch and others, 2007, fig. 27).

${ }^{4}$ Based on grassland range (Welch and others, 2007, fig. 27).

${ }^{5}$ Based on the upper end of the grassland (Welch and others, 2007, fig. 27) and the net irrigation water requirement for alfalfa in Snake Valley (Huntington and Allen, 2010).

${ }^{6}$ Open water rate for Snake Valley (Huntington and Allen, 2010). 
Groundwater evapotranspiration rates were applied to vegetated ET units, open water, and the Tule Valley playa to estimate total $\mathrm{ET}_{\mathrm{g}}$ for the study area. Vegetated $\mathrm{ET}$ units and open water were mapped using Landsat satellite imagery collected by the Thematic Mapper (TM) sensor aboard Landsat 5. The TM instrument collects information in six spectral bands with wavelengths ranging from the visible blue $(0.45$ micrometer, $\mu \mathrm{m})$ to the short-wave infrared $(2.35 \mu \mathrm{m})$, and in an additional seventh band with thermal infrared wavelengths between 10.4 and $12.5 \mu \mathrm{m}$. Continuous 112-milewide swaths of TM imagery are broken into overlapping "scenes" approximately $105 \mathrm{mi}$ in length. Each scene is imaged by the sensor every 16 days at approximately 100 -foot (30-meter) spatial resolution (394 feet [120 meters] for the thermal band) and covers approximately 11,800 $\mathrm{mi}^{2}$. Landsat $5 \mathrm{TM}$ scene locations are identified using a world reference system 2 (WRS2) path and row number. The Tule Valley and Sevier Lake GDAs and the ET stations used to evaluate scenes are in WRS2 path 39 row 33. As part of the BARCAS study, nine scenes were selected for evaluation against vegetation conditions and six stations were measured for ET in Spring, Snake, and White River Valleys, which are west of the study area (table 3; Moreo and others, 2007). Stations were installed in August 2005 and removed after September 30, 2006 (Moreo and others, 2007).

The selected scenes represent a subset of available images for each year where skies were cloud-free, vegetation canopies were green and active, and little to no antecedent precipitation was observed at nearby weather stations. All scenes were selected starting in 2005 through 2011 and acquired by the Landsat $5 \mathrm{TM}$ sensor in the summer months to represent "growing-season" conditions when phreatophytic vegetation in the GDA is actively transpiring and shrubs have reached maximum growth. Early scene dates were

Table 3. Landsat 5 Thematic Mapper scenes evaluated for use in basin-scale estimation of groundwater evapotranspiration in the Tule Valley and Sevier Lake groundwater discharge areas, Utah.

[ID, identification]

\begin{tabular}{lc}
\hline \multicolumn{1}{c}{ Image date } & Landsat image entity ID \\
\hline July 12, 2005 & LT50390332005193PAC01 \\
July 15, 2006 & LT50390332006196PAC01 \\
July 2, 2007 & LT50390332007183PAC01 \\
July 7, 2007 & LT50390332009188PAC01 \\
July 18, 2007 & LT50390332007199PAC01 \\
June 18, 2008 & LT50390332008170PAC01 \\
August 21, 2008 & LT50390332008234PAC01 \\
August 11, 2010 & LT50390332010223EDC00 \\
June 27, 2011 & LT50390332011178PAC01 \\
\hline
\end{tabular}

selected to roughly coincide with installation of BARCAS study ET stations. No scenes were available for 2012 because of the failure of the TM sensor aboard Landsat 5 during the late winter of 2012. Landsat 8 scenes from 2013 were not evaluated because of slight spectral and radiometric differences between the sensors and because the atmospheric correction method used (described below) was not available for Landsat 8 at the time of processing. Data were assessed from 2005 through 2011 to provide a large group of data for comparison with the site-scale ET data.

Each scene date was atmospherically corrected by the USGS Earth Resources Observation and Science (EROS) Center using Landsat Ecosystem Disturbance Adaptive Processing System (LEDAPS) software. LEDAPS software applies atmospheric corrections to Landsat data to generate a surface reflectance product. The corrections are based on the Second Simulation of a Satellite Signal in the Solar Spectrum (6S) radiative transfer model used by the Moderate Resolution Imaging Spectroradiometer (MODIS) Land Science Team (U.S. Geological Survey, 2012). The atmospherically corrected visible, near infrared, and short-wave infrared bands were combined to form a single 6-band image for each scene date.

Information from multispectral satellite imagery such as that collected by Landsat $5 \mathrm{TM}$ can be used to characterize vegetation on the basis of light absorption and reflection characteristics unique to vegetated surfaces. Vegetation indices such as the Normalized Difference Vegetation Index (NDVI; Rouse and others, 1974), Modified Soil-Adjusted Vegetation Index (MSAVI; Qi and others, 1994), and the Enhanced Vegetation Index (EVI; Huete and others, 1999) use the contrast between distinct absorption and reflectance features in vegetation to help identify vegetated areas and to characterize the health and spatial extent of vegetation communities. Calculation of a vegetation-index results in a unitless singleband image with valid values ranging between -1 and 1 . Index values in vegetated areas are nearly always greater than 0 and, in general, the healthier and denser the vegetation, the higher the vegetation-index value. Different vegetation species at 100-percent cover can have different vegetation-index values as a result of varying chlorophyll content, internal leaf structure, and canopy structure (Glenn and others, 2008).

These variations can reduce the significance of relationships between the vegetation index and vegetation cover. Vegetation indices that are based on a simple combination of the near infrared and red wavelengths such as the NDVI are sensitive to the quantity of green leaf vegetation in a scene, but also are influenced by the composite background reflectance of the soil surface, plant litter, and woody plant material, particularly in areas of moderate-to-sparse vegetation cover. The MSAVI and EVI are in a group of vegetation indices that use a canopy background adjustment factor to reduce the influence of soil and background reflectance on the index to increase the signal from healthy vegetation in the image. 
The Normalized Difference Vegetation Index, NDVI, EVI, and MSAVI were calculated from nine atmospherically corrected 2005-11 summer Landsat 5 TM scenes selected for evaluation. Each calculated vegetation-index image was evaluated for its effectiveness in predicting $\mathrm{ET}_{\mathrm{g}}$, which is assumed directly proportional to phreatophytic shrub density. The evaluation was done by comparing area-weighted averages of vegetation-index values in the source area for each ET site with ET $\mathrm{g}_{\mathrm{g}}$ computed from each site (Moreo and others, 2007) using ordinary least-squares regression. Coefficients of determination $\left(\mathrm{r}^{2}\right)$ for all the vegetation indices evaluated were consistently above 0.8 (table 4 ). The Modified Soil-Adjusted Vegetation Index regularly exhibited $\mathrm{r}^{2}$ equal to or better than the other vegetation indexes for all images evaluated and was selected for basin-scale $\mathrm{ET}_{\mathrm{g}}$ estimation.

Vegetation assemblages, or ET units, outside the playa boundaries were determined from the MSAVI images. Each image was partitioned into five ET units (open water, very sparse desert shrub, sparse-to-dense desert shrub, grassland, and dense meadow and marshland; fig. 8) using threshold values determined from information gathered during field reconnaissance and mapping of the GDAs in conjunction with NAIP and Landsat imagery. Evapotranspiration estimates for vegetated ET units were calculated by linearly scaling the ET-rate range so that the highest ET rate was assigned to the highest MSAVI value in the ET unit and the lowest ET rate was assigned to the lowest MSAVI value in the ET unit, in the same manner as described in Welch and others (2007). Discharge for the Tule Valley playa and open water ET units were calculated using a single rate across the area of each unit (table 2). Calculations were made for each individual summer scene and for a 2007-08 midsummer mean scene calculated as the mean of MSAVI for the July 18, 2007, and August 21, 2008 , scenes. These scenes were selected to calculate the midsummer average because they exhibited the highest $\mathrm{r}^{2}$ values when compared with $\mathrm{ET}_{\mathrm{g}}$ from the BARCAS study ET stations.

Table 4. Coefficients of determination describing relations between vegetation indexes and site-scale groundwater evapotranspiration $\left(\mathrm{ET}_{\mathrm{g}}\right)$ in the Spring, Snake, and White River Valleys, Nevada and Utah.

[in/yr, inches per year; NDVI, normalized difference vegetation index; EVI, enhanced vegetation index; MSAVI, modified soil adjusted vegetation index]

\begin{tabular}{|c|c|c|c|c|c|c|c|c|c|c|}
\hline Site & $\begin{array}{c}\mathrm{ET}^{g} \\
(\mathrm{in} / \mathrm{yr})^{1}\end{array}$ & $\begin{array}{c}\text { July 12, } \\
2005\end{array}$ & $\begin{array}{l}\text { July 15, } \\
2006\end{array}$ & $\begin{array}{c}\text { July 2, } \\
2007\end{array}$ & $\begin{array}{c}\text { July 7, } \\
2007\end{array}$ & $\begin{array}{c}\text { July 18, } \\
2007\end{array}$ & $\begin{array}{c}\text { June 18, } \\
2008 \\
\end{array}$ & $\begin{array}{c}\text { August 21, } \\
2008\end{array}$ & $\begin{array}{c}\text { August 11, } \\
2010\end{array}$ & $\begin{array}{c}\text { June 27, } \\
2011\end{array}$ \\
\hline \multicolumn{11}{|c|}{ Mean source area, NDVI } \\
\hline WRV-2 & 0.77 & 0.21 & 0.17 & 0.16 & 0.16 & 0.13 & 0.17 & 0.14 & 0.17 & 0.17 \\
\hline SPV-1 & 1.44 & 0.12 & 0.11 & 0.11 & 0.10 & 0.11 & 0.12 & 0.10 & 0.12 & 0.12 \\
\hline SPV-2 & 2.9 & 0.16 & 0.14 & 0.14 & 0.13 & 0.14 & 0.14 & 0.13 & 0.16 & 0.16 \\
\hline SNV-1 & 3.82 & 0.16 & 0.14 & 0.14 & 0.12 & 0.13 & 0.14 & 0.13 & 0.14 & 0.16 \\
\hline WRV-1 & 3.89 & 0.25 & 0.20 & 0.19 & 0.17 & 0.18 & 0.19 & 0.17 & 0.17 & 0.18 \\
\hline SPV-3 & 18.97 & 0.51 & 0.36 & 0.34 & 0.39 & 0.29 & 0.43 & 0.27 & 0.27 & 0.45 \\
\hline Coefficie & ion $\left(r^{2}\right)$ & 0.90 & 0.89 & 0.93 & 0.92 & 0.92 & 0.94 & 0.90 & 0.86 & 0.97 \\
\hline \multicolumn{11}{|c|}{ Mean source area, EVI } \\
\hline WRV-2 & 0.77 & 0.16 & 0.13 & 0.13 & 0.12 & 0.11 & 0.13 & 0.10 & 0.14 & 0.13 \\
\hline SPV-1 & 1.44 & 0.12 & 0.11 & 0.12 & 0.10 & 0.11 & 0.12 & 0.10 & 0.13 & 0.12 \\
\hline SPV-2 & 2.9 & 0.14 & 0.13 & 0.13 & 0.12 & 0.12 & 0.13 & 0.12 & 0.14 & 0.14 \\
\hline SNV-1 & 3.82 & 0.14 & 0.12 & 0.12 & 0.10 & 0.11 & 0.12 & 0.11 & 0.12 & 0.13 \\
\hline WRV-1 & 3.89 & 0.19 & 0.15 & 0.15 & 0.14 & 0.14 & 0.15 & 0.13 & 0.13 & 0.14 \\
\hline SPV-3 & 18.97 & 0.39 & 0.27 & 0.28 & 0.29 & 0.23 & 0.34 & 0.20 & 0.22 & 0.35 \\
\hline Coefficic & ion $\left(r^{2}\right)$ & 0.94 & 0.95 & 0.98 & 0.95 & 0.97 & 0.97 & 0.96 & 0.90 & 0.98 \\
\hline \multicolumn{11}{|c|}{ Mean source area, MSAVI } \\
\hline WRV-2 & 0.77 & 0.13 & 0.11 & 0.10 & 0.10 & 0.09 & 0.11 & 0.08 & 0.11 & 0.11 \\
\hline SPV-1 & 1.44 & 0.10 & 0.09 & 0.09 & 0.08 & 0.09 & 0.10 & 0.08 & 0.10 & 0.10 \\
\hline SPV-2 & 2.9 & 0.11 & 0.10 & 0.11 & 0.10 & 0.10 & 0.11 & 0.10 & 0.12 & 0.12 \\
\hline SNV-1 & 3.82 & 0.12 & 0.10 & 0.10 & 0.09 & 0.10 & 0.10 & 0.09 & 0.11 & 0.11 \\
\hline WRV-1 & 3.89 & 0.15 & 0.12 & 0.12 & 0.11 & 0.11 & 0.13 & 0.11 & 0.11 & 0.12 \\
\hline SPV-3 & 18.97 & 0.35 & 0.22 & 0.24 & 0.25 & 0.20 & 0.29 & 0.18 & 0.19 & 0.30 \\
\hline Coeffici & ion $\left(\mathrm{r}^{2}\right)$ & 0.95 & 0.95 & 0.98 & 0.96 & 0.98 & 0.97 & 0.97 & 0.93 & 0.98 \\
\hline
\end{tabular}

${ }^{1}$ Moreo and others (2007). 
Vegetation variations owing to the presence of excess soil moisture, annual plants, and biological soil crusts may cause variation in $\mathrm{ET}_{\mathrm{g}}$ calculations. At the Tule Valley RAWS station, examination of long-term precipitation records showed wetter than normal conditions in April and May of 2005 and 2010 as well as April-August 2011. Groundwater evapotranspiration calculated from the 2005, 2010, and 2011 scenes was discarded for that reason. The July 2, 2007, scene also resulted in anomalously high $\mathrm{ET}_{\mathrm{g}}$ possibly because of the presence of annual plants (plants with a life cycle that lasts only one year) in the scene. Exact causes of scene variation are unknown, but they are thought to be associated with ecosystem response to precipitation pulses. Ecosystem function in arid environments is a function of precipitation timing and amount; and seed germination is typically triggered by rainfall that exceeds a minimum amount (Schwinning and Sala, 2004). It was observed during this study that a wetter than normal spring or fall appeared to trigger annual plants to germinate in larger numbers than in average years. In the end, MSAVI values for the 2007-08 midsummer mean scene were determined to best represent the long-term distribution of phreatophytic vegetation in the GDAs of interest and used to apply scaled ET-rate ranges to each ET unit.

\section{Limitations of Methodology}

Groundwater-evapotranspiration rates could vary due to varying hydrologic conditions including local precipitation amounts, soil texture, aquifer properties, surface morphology, and discharge area characteristics. This study assumes that the general rates applied to ET units are appropriate for the vegetation conditions and hydrologic properties of the valleys in the study area. Valleys in the study area are lower in elevation than valleys from which ET rates were estimated during the BARCAS study. Lower elevation valleys may experience warmer growing season temperatures and increased ET as a result. Variations in satellite imagery due to pixel shifts, incomplete atmospheric corrections, and local precipitation events also can result in variations in ET $_{\mathrm{g}}$ calculations.

\section{Groundwater Geochemistry}

Geochemical analyses are presented for water samples collected from 13 sites in Pine Valley and 11 sites in Wah Wah Valley. Groundwater sampling sites included a total of 12 observation, domestic, and stock wells and 12 perennial springs (table 5). The water samples were analyzed for major ions, nutrients, and selected trace metals to characterize general geochemistry and patterns of water quality. Water samples also were analyzed for a suite of environmental tracers that included the stable isotopes of oxygen $\left(\delta^{18} \mathrm{O}\right)$, and hydrogen $\left(\delta^{2} \mathrm{H}\right)$, and carbon $\left(\delta^{13} \mathrm{C}\right)$; the radioactive isotopes of carbon $\left({ }^{14} \mathrm{C}\right)$ and hydrogen $\left({ }^{3} \mathrm{H}\right)$; and dissolved noble gases including ${ }^{3} \mathrm{He},{ }^{4} \mathrm{He},{ }^{20} \mathrm{Ne},{ }^{40} \mathrm{Ar},{ }^{84} \mathrm{Kr},{ }^{129} \mathrm{Xe}$, respectively. These environmental tracers and major-ion chemistry were used to investigate sources of recharge, groundwater flow paths, and groundwater ages to support the development of a conceptual model of the groundwater systems in these basins. What follows is an abridged description of the use of environmental tracer data in hydrologic conceptual model development; more detail is provided in Gardner and Heilweil (2014) and references therein.

Tritium is a radioactive isotope of hydrogen that can exist as part of a water molecule and is present in water worldwide in small concentrations. Tritium was used in this study to detect the presence of modern (post-1950s nuclear testing) groundwater and, combined with ${ }^{3} \mathrm{He}$, evaluate groundwater age. Water containing greater than 0.4 tritium units (TU) is assumed to contain at least a fraction of modern water. The isotopes of ${ }^{3} \mathrm{He}$ and ${ }^{4} \mathrm{He}$ were apportioned into concentrations that originated from the atmosphere, tritium decay $\left({ }^{3} \mathrm{He}_{\text {trit }}\right)$, and uranium/thorium-series decay in the crust (terrigenic helium- $\left.4,{ }^{4} \mathrm{He}_{\text {terr }}\right)$. In this analysis of ${ }^{4} \mathrm{He}_{\text {terr }}$, the mantle was not considered as a source of helium $(\mathrm{He})$ gas.

The ${ }^{3} \mathrm{He}_{\text {trit }}$ fraction is the radioactive decay product of ${ }^{3} \mathrm{H}$ and the concentration of both are used for ${ }^{3} \mathrm{H} /{ }^{3} \mathrm{He}$ trit dating. Apparent ${ }^{3} \mathrm{H} /{ }^{3} \mathrm{He}_{\text {trit }}$ ages were computed for samples having concentrations greater than $0.4 \mathrm{TU}$ where ${ }^{3} \mathrm{He}$ also was measured. Modern precipitation is assumed to contain 6-9 TU in the study area (Gardner and Heilweil, 2014). Because the addition of ${ }^{3} \mathrm{H}$-free water does not appreciably alter the ${ }^{3} \mathrm{H} /{ }^{3} \mathrm{He}_{\text {trit }}$ ratio, apparent ${ }^{3} \mathrm{H}$ ages calculated for mixed waters only represent the age of the young fraction of that mixture.

Terrigenic helium-4 was used in this study as a qualitative dating tool that helped identify and categorize samples of mixed age when its abundance is considered along with ${ }^{3} \mathrm{H} /{ }^{3} \mathrm{He}$ and radiocarbon ages. Analysis of local ${ }^{4} \mathrm{He}_{\text {terr }}$ production rates was outside the scope of this study and no attempt was made to accurately date groundwater using ${ }^{4} \mathrm{He}_{\text {terr }}$. However, Solomon (2000) reported average crustal ${ }^{4} \mathrm{He}$ production rates ranging from 0.28 to $2.4 \mu \mathrm{ccSTP}$ (micro cubic centimeters at standard temperature and pressure) per cubic meter $\left(\mathrm{m}^{3}\right)$ per year; at these rates, groundwater will not acquire significant concentrations of ${ }^{4} \mathrm{He}_{\text {terr }}$ (more than about $2 \times 10^{-8}$ cubic centimeters at standard temperature and pressure per gram $[\mathrm{ccSTP} / \mathrm{g}]$ until it has been in contact with aquifer materials for more than 1,000 years. Therefore, even without precise knowledge of local production rates, ${ }^{4} \mathrm{He}_{\text {terr }}$ is particularly useful for identifying old water in samples of mixed age because it is often elevated by orders of magnitude in old waters and not easily disguised by dilution with young groundwater. 
Table 5. Selected attributes of groundwater sites with chemical analyses from Pine and Wah Wah Valleys and surrounding areas, Utah.

[Sample identification (ID): See figure 10 for locations. Horizontal coordinate information is referenced to the North American Datum of 1983 (NAD 83). Abbreviations: USGS, U.S. Geological Survey; $\mathrm{mm} / \mathrm{dd} / \mathrm{yyyy}$, month/day/year; LCAU, lower carbonate aquifer unit; VU, volcanic unit; —, no information; NCCU, non-carbonate confining unit; USCU, upper siliciclastic confining unit]

\begin{tabular}{|c|c|c|c|c|c|c|c|c|c|c|}
\hline $\begin{array}{l}\text { Sample } \\
\text { ID }\end{array}$ & USGS site number & USGS site name & Site type & $\begin{array}{l}\text { Latitude } \\
\text { (decimal } \\
\text { degrees) }\end{array}$ & $\begin{array}{l}\text { Longitude } \\
\text { (decimal } \\
\text { degrees) }\end{array}$ & $\begin{array}{l}\text { Well } \\
\text { depth } \\
\text { (feet) }\end{array}$ & $\begin{array}{l}\text { Depth to top } \\
\text { and bottom } \\
\text { of openings } \\
\text { (feet) }\end{array}$ & $\begin{array}{c}\text { Altitude } \\
\text { of land } \\
\text { surface } \\
\text { (feet) }\end{array}$ & Hydrogeologic unit & $\begin{array}{l}\text { Sample date } \\
\text { (mm/dd/yyyy) }\end{array}$ \\
\hline 1 & 382901113295701 & (C-27-15)11aba-S1 & Spring (piezometer) & 38.483556 & -113.499194 & 3.5 & $2.5-3.5$ & 5,665 & LCAU/VU & $12 / 04 / 2012$ \\
\hline 2 & 382856113293301 & $(\mathrm{C}-27-15) 12 \mathrm{bbc}-1$ & Spring (piezometer) & 38.482083 & -113.492417 & 4.1 & $3.1-4.1$ & 5,532 & LCAU/VU & $12 / 04 / 2012$ \\
\hline 3 & 382344113305901 & (C-28-15)10abb-S1 & Spring & 38.395639 & -113.517194 & - & - & 5,850 & LCAU/VU & $12 / 04 / 2012$ \\
\hline 4 & 382016113364001 & (C-28-16)35bac-S1 & Spring & 38.337444 & -113.611944 & - & - & 7,210 & LCAU & $12 / 05 / 2012$ \\
\hline 5 & 381045113470701 & (C-30-17)19ddc-S1 & Spring & 38.179167 & -113.785167 & - & - & 6,900 & Basin fill/VU & $12 / 06 / 2012$ \\
\hline 6 & 382445113501401 & $(\mathrm{C}-27-18) 35 \mathrm{ccb}-1$ & Spring (piezometer) & 38.412611 & -113.837139 & 2.5 & $1.5-2.5$ & 6,275 & Basin fill/VU/LCAU & $12 / 05 / 2012$ \\
\hline 7 & 382550113504001 & $(\mathrm{C}-27-18) 27 \mathrm{dba}-1$ & Spring (piezometer) & 38.430639 & -113.844444 & - & - & 6,335 & Basin fill/LCAU/VU & $12 / 05 / 2012$ \\
\hline 8 & 383131113214301 & (C-26-14)25aad-1 & Observation well & 38.525250 & -113.362750 & 1,135 & $888-1,114$ & 4,760 & Basin fill & $12 / 06 / 2012$ \\
\hline 9 & 383538113450801 & (C-25-17)33dab-1 & Domestic well & 38.593861 & -113.753028 & 628 & - & 5,275 & Basin fill & $12 / 03 / 2012$ \\
\hline 10 & 381344113512301 & (C-30-18) 3bcc-1 & Domestic well & 38.228861 & -113.856278 & 430 & $390-430$ & 7,805 & VU & $10 / 23 / 2013$ \\
\hline 11 & 383402113440601 & (C-26-17) 3cda-1 & Observation well & 38.572861 & -113.742000 & 882 & $640-861$ & 5,248 & Basin fill & $08 / 28 / 2013$ \\
\hline 12 & 382259113433701 & (C-28-17)11cca-1 & Observation well & 38.383015 & -113.727751 & 970 & $270-970$ & 5,683 & Basin fill & $10 / 02 / 2013$ \\
\hline 13 & 381152113442801 & (C-30-17)15cab-1 & Domestic well & 38.197833 & -113.741167 & 385 & $365-385$ & 6,550 & Basin fill & $08 / 29 / 2013$ \\
\hline 14 & 382539113250601 & (C-27-14)28ddd-2 & Observation well & 38.427461 & -113.419134 & 987 & $780-1,320$ & 5,085 & Basin fill & $08 / 27 / 2013$ \\
\hline 15 & 382101113170801 & (C-28-13)26bbd-1 & Stock well & 38.350306 & -113.285500 & 200 & $100-200$ & 6,160 & VU & $09 / 18 / 2013$ \\
\hline 16 & 381957113163701 & $(\mathrm{C}-28-13) 35 \mathrm{acc}-1$ & Stock well & 38.332583 & -113.277028 & - & - & 6,240 & VU & $09 / 18 / 2013$ \\
\hline 17 & 382423113243601 & (C-28-14) 3bcd-1 & Observation well & 38.406500 & -113.414083 & 1,480 & $700-1,480$ & 5,210 & Basin fill/VU & $10 / 21 / 2013$ \\
\hline${ }^{1} 18$ & 383825113410801 & (C-25-16)18bdd-1 & Stock/observation well & 38.640300 & -113.685684 & 340 & - & 5,085 & Basin fill & $06 / 15 / 2011$ \\
\hline${ }^{1} 19$ & 384042113181601 & $(\mathrm{C}-24-13) 34 \mathrm{ccb}-1$ & Stock well & 38.678154 & -113.305320 & 294 & - & 4,655 & Basin fill & $06 / 15 / 2011$ \\
\hline 120 & 381848113292701 & (C-29-15) 2dad-S1 & Spring & 38.313130 & -113.491750 & - & - & 6,150 & VU & $06 / 28 / 2011$ \\
\hline${ }^{1} 21$ & 382238113205301 & (C-28-13)18adb-S1 & Spring & 38.377350 & -113.348880 & - & - & 5,530 & Basin fill/VU & $06 / 28 / 2011$ \\
\hline 122 & 381702113383101 & (C-29-16)16dbd-S1 & Spring & 38.283851 & -113.642749 & - & - & 7,320 & $\mathrm{NCCU}$ & $10 / 02 / 2008$ \\
\hline${ }^{1} 23$ & 382024113502101 & (C-28-18)27dda-S1 & Spring & 38.339960 & -113.839975 & - & - & 6,670 & VU & $10 / 02 / 2008$ \\
\hline${ }^{124}$ & 383452113572301 & (C-26-19) 3abc-S1 & Spring & 38.581160 & -113.957250 & - & - & 7,150 & USCU & $06 / 16 / 2011$ \\
\hline
\end{tabular}

'Sample collected by the Utah Geological Survey and reported in Gardner and Heilweil (2014). 
The source of He is distinguishable by the relative abundance of ${ }^{3} \mathrm{He}$ and ${ }^{4} \mathrm{He}$ isotopes, which can be expressed as $\mathrm{R} / \mathrm{R}_{\mathrm{a}}$. With $\mathrm{R}$ defined as the ${ }^{3} \mathrm{He} /{ }^{4} \mathrm{He}$ ratio in groundwater and $\mathrm{R}_{\mathrm{a}}$ as the atmospheric ${ }^{3} \mathrm{He} /{ }^{4} \mathrm{He}$ ratio, groundwater in contact with the atmosphere has an $\mathrm{R} / \mathrm{R}_{\mathrm{a}}$ value of 1 , and groundwater containing crustal helium will have an $R / R_{a}$ value less than 1 and approaching 0.01. Because He dissolved in groundwater is conservative and not subject to radioactive decay (unlike ${ }^{3} \mathrm{H}$ or ${ }^{14} \mathrm{C}$ ) or dilution by chemical reaction (for example, ${ }^{14} \mathrm{C}$ reaction with carbonate $\left[\mathrm{CO}_{3}\right]$ minerals), $\mathrm{R} / \mathrm{R}$ in groundwater generally decreases with age as it acquires crustal ${ }^{4} \mathrm{He}_{\text {terr }}$. Conversely, ${ }^{3} \mathrm{H}$ decay increases ${ }^{3} \mathrm{He}_{\text {trit }}$ in modern waters and can result in $\mathrm{R} / \mathrm{R}_{\mathrm{a}}$ values slightly greater than 1 .

Carbon-14 was used to estimate the age of groundwater in Pine and Wah Wah Valleys that is more than about 2,000 years old. Unadjusted radiocarbon ages were calculated from non-normalized ${ }^{14} \mathrm{C}$ activities of dissolved inorganic carbon using the Libby half-life (5,568 years), assuming an initial ${ }^{14} \mathrm{C}$ activity of 100 percent modern carbon (pmC). Radiocarbon age adjustments were made using the formulabased inorganic adjustment model of Fontes and Garnier (1979). The adjustment model used standard assumptions for the ${ }^{14} \mathrm{C}$ activities of carbonate minerals and soil gas carbon dioxide $\left(\mathrm{CO}_{2} ; 0\right.$ and $100 \mathrm{pmC}$, respectively) and $\delta^{13} \mathrm{C}$ of carbonate minerals ( 0 permil; Plummer and Sprinkle, 2001; Kennedy and Genereux, 2007). Soil gas $\mathrm{CO}_{2}$ was assumed to have a $\delta^{13} \mathrm{C}$ value of -22 permil based on the reported average for similar terrain in Utah (Hart and others, 2010). Because it is recognized that atmospheric ${ }^{14} \mathrm{C}$ has not been constant (de Vries, 1958), radiocarbon ages were calibrated to years before present (BP) using the IntCal13 radiocarbon calibration curve (Stuiver and others, 2005; Reimer and others, 2013). Calibrated Fontes and Garnier (F\&G) adjusted ages are considered conservative and representative of the true age of water in the region with an uncertainty of up to several thousand years (Gardner and Heilweil, 2014). If the model resulted in an unreasonable (negative) age, the adjusted age was designated as either modern (recharge after the mid1950s), pre-modern (recharge before the mid-1950s), or as a mixture of modern and pre-modern water based on evaluating other age-related tracers.

The stable isotopes of water were used to better understand recharge sources to the groundwater basin. Stable isotopes are analyzed by measuring the ratio of the heavier, less abundant isotope (oxygen- $18,{ }^{18} \mathrm{O}$; or deuterium, ${ }^{2} \mathrm{H}$ ) to the lighter, more abundant (common) isotope (oxygen-16, ${ }^{16} \mathrm{O}$; or $\left.{ }^{1} \mathrm{H}\right)$. The values are reported as differences $(\delta$, delta) relative to a reference standard known as Vienna Standard Mean Ocean Water (VSMOW) in parts per thousand (permil; Craig, 1961b; Coplen, 1994). The proportional variation in ${ }^{2} \mathrm{H}$ and ${ }^{18} \mathrm{O}$ results in isotopic compositions of precipitation (and groundwater sourced from precipitation) that plot along a linear trend referred to as a meteoric water line when $\delta^{2} \mathrm{H}$ is plotted against $\delta^{18} \mathrm{O}$. For a given area, where a sample plots on this trend is indicative of the season (winter versus summer) and altitude (mountain versus valley) that the precipitation fell in/at before recharging an aquifer.

Dissolved noble-gas samples $\left({ }^{20} \mathrm{Ne},{ }^{40} \mathrm{Ar},{ }^{84} \mathrm{Kr}\right.$, and $\left.{ }^{129} \mathrm{Xe}\right)$ were used to determine noble-gas recharge temperatures (NGTs, assumed to equal the temperature of groundwater recharge as it crosses the water table) as an indicator of mountain versus valley recharge. Interpretation of NGTs for this purpose assumes a relationship exists between recharge altitude $\left(\mathrm{H}_{\mathrm{r}}\right)$ and recharge temperature that mirrors a typical air-temperature lapse rate so that mountain recharge will have cooler temperatures than recharge occurring in adjacent valleys. The existence of this $\mathrm{H}_{\mathrm{r}} \mathrm{NGT}$ relationship for the region including these basins is demonstrated in supplemental material provided in Gardner and Heilweil (2014). Noble gases dissolved in groundwater are primarily of atmospheric origin and their concentrations dissolved in water are a function of their solubility with the possible addition of excess air. Noble-gas concentrations and groundwater NGTs should be preserved along a groundwater flow path because most noble gases are geochemically inert and unlike physical temperatures and age tracers $\left({ }^{14} \mathrm{C},{ }^{4} \mathrm{He}_{\text {terr }}\right.$, and $\left.{ }^{3} \mathrm{H} / 3 \mathrm{He}_{\text {trit }}\right)$ that change with time.

Noble-gas concentrations were used in the closedsystem equilibration (CE) model (Aeschbach-Hertig and others, 2000; Kipfer and others, 2002) to calculate NGTs. Recharge altitude (the proxy for barometric pressure) was an unknown parameter in this model, which is a typical situation in locations with high topographic relief. Because the NGTs and $\mathrm{H}_{\mathrm{r}}$ are correlated, a range of NGTs was calculated for each sample as described by Manning and Solomon (2003) and Manning (2011). This range consists of using a minimum recharge altitude $\left(\mathrm{H}_{\min }\right)$, typically that of the sample site, to calculate a maximum noble-gas recharge temperature $\left(\mathrm{NGT}_{\max }\right)$. Conversely, the maximum recharge altitude $\left(\mathrm{H}_{\max }\right)$ in a basin is used to calculate a minimum noble-gas recharge temperature $\left(\mathrm{NGT}_{\min }\right.$ ). The value of $\mathrm{H}_{\max }$ for each sample was selected to include the highest water-table altitude where recharge could have occurred and is based on the altitude of the highest observed springs in a contributing area. For this study, $\mathrm{H}_{\max }$ was assumed to be 8,400 and $8,000 \mathrm{ft}$ for samples collected from valley wells in the Pine and Wah Wah Valley drainage basins, respectively. Maximum recharge altitude was assumed to be between 6,600 and 8,400 ft for samples collected from mountain springs and wells depending on their location. Average recharge altitude $\left(\mathrm{H}_{\text {avg }}\right)$ and average noble-gas recharge temperature $\left(\mathrm{NGT}_{\text {avg }}\right.$ ) also are calculated using the mid-point altitude and are assumed to represent the actual recharge temperature of the sample with the minimum and maximum values representing a conservative range of uncertainty. Uncertainty in NGTs owing to noble-gas measurement precision is generally $0.5-1.5^{\circ} \mathrm{C}$ (Manning and Solomon, 2003; Manning, 2009; Masbruch and others, 2012). 


\section{Major Ions, Nutrients, and Selected Trace Metals}

Dissolved major-ion, nutrient, and selected trace-metal concentrations in groundwater samples were analyzed to assess general water-quality conditions and to evaluate groundwater source areas and flow paths in Pine and Wah Wah Valleys (table 6). Concentrations of dissolved solids for all sites ranged from 120 to $1,290 \mathrm{mg} / \mathrm{L}$ and exceeded the U.S. Environmental Protection Agency (EPA) secondary standard of $500 \mathrm{mg} / \mathrm{L}$ for drinking water (U.S. Environmental Protection Agency, 2014) at only six of the twenty-four sample sites (sites 3, 6, 16, 19, 20, and 24). Additional exceedances of EPA secondary standards include two sites with elevated manganese (sites 6 and 14) and one with elevated sulfate (site 24). Trace metals were sampled for only 17 of the 24 sites. Arsenic was reported to exceed the EPA maximum contaminant levels (MCL) of 10 micrograms per liter $(\mu \mathrm{g} / \mathrm{L})$ in a supply well at the Desert Experimental Range and an observation well in Pine Valley (sites 9 and 11), as well as in one stock well in the volcanic bedrock hills of southwestern Wah Wah Valley (site 16). Arsenic is likely derived from alluvial sediments eroded from extensive volcanic rocks in the surrounding mountains. Nutrient (nitrate plus nitrite) concentrations in all samples were well below the EPA MCL of $10 \mathrm{mg} / \mathrm{L}$ (table 6).

The principal dissolved constituents in most samples were calcium, sodium, bicarbonate, and chloride, all of which are directly derived from dissolution of the carbonate and volcanic rocks and alluvium eroded from these rocks that are abundant throughout the study area. Stiff diagrams and a piper plot illustrate the differences, often subtle, in water types across the study area (figs. 10,11). There are notable differences in groundwater major-ion chemistry between the Pine and Wah Wah Valley drainage basins as well between mountain and valley groundwaters in each drainage basin. For this reason, further sample results are presented in the following four groups (1) Pine Valley-mountain groundwater (PV-mountain groundwater); (2) Pine Valleyvalley groundwater (PV-valley groundwater); (3) Wah Wah Valley-mountain groundwater (WW-mountain groundwater); and (4) Wah Wah Valley-valley groundwater (WW-valley groundwater). Mountain groundwaters were sampled from springs and wells screened in bedrock or shallow alluvium in the foothills or mountains adjacent to the valleys and well above the valley floors. Valley groundwaters were all sampled from relatively deep (298-1,480-ft deep) alluvial wells generally along the central axis of each valley.

Samples representing PV-mountain groundwater (sites 4, $5,6,7,10,13,22,23$, and 24) are dominantly calciumbicarbonate $\left(\mathrm{Ca}-\mathrm{HCO}_{3}\right)$ waters. Apart from one spring (site 22) that discharges from quartzite talus at more than $7,300 \mathrm{ft}$ with a dissolved-solids concentration of $120 \mathrm{mg} / \mathrm{L}$, all $\mathrm{PV}$-mountain groundwaters had dissolved-solids concentrations ranging from 239 to $872 \mathrm{mg} / \mathrm{L}$. Samples representing PV-valley groundwater (sites $9,11,12$, and 18) were dominantly sodiumbicarbonate $\left(\mathrm{Na}-\mathrm{HCO}_{3}\right)$ or calcium-sodium-bicarbonate $\left(\mathrm{Ca}-\mathrm{Na}-\mathrm{HCO}_{3}\right.$ ) water with dissolved-solids concentrations ranging from 212 to $234 \mathrm{mg} / \mathrm{L}$, all lower than eight of the nine PV-mountain groundwaters sampled.

Samples representing WW-mountain groundwater (sites 1, 2, 3, 15, 16, 20, and 21) have major-ion chemical signatures that differ on the east and west sides of the basin. Sites 1 and 2 are different discharge points that are both a part of the Wah Wah Springs complex and separated by about $0.4 \mathrm{mi}$. These sites have nearly identical chemistry for all analytes except for elevated iron and manganese in site 2 that is likely associated with oxidation of the steel piezometer from which the sample was collected. Samples from the Wah Wah Range on the west side of the valley are all $\mathrm{Ca}-\mathrm{HCO}_{3}$ waters with dissolved-solids concentrations ranging from 336 to $575 \mathrm{mg} / \mathrm{L}$. Samples collected from springs and wells in the hills that bound Wah Wah Valley to the southeast are calciumchloride or sodium-calcium-chloride waters with dissolvedsolids concentrations ranging from 387 to $712 \mathrm{mg} / \mathrm{L}$. Samples representing WW-valley groundwater (sites $8,14,17$, and 19) are dominantly sodium-chloride $(\mathrm{Na}-\mathrm{Cl})$ waters except for the southernmost (site 17), which is calcium-sodium-bicarbonate water. The northernmost of these (site 19) is on the edge of the Wah Wah Valley dry playa and within several miles of Sevier Lake. This site had $1,290 \mathrm{mg} / \mathrm{L}$ of dissolved solids, dominantly sodium-chloride, and likely caused by dissolution of evaporite minerals in the subsurface. The three southernmost WW-valley groundwater samples (sites 8, 14, and 17) had dissolved-solids concentrations ranging from 318 to $432 \mathrm{mg} / \mathrm{L}$. These samples had major-ion chemical signatures that most closely resemble WW-mountain groundwaters in the southeast portion of the basin (sites 15 and 21) and that are distinctly different than WW-mountain groundwaters sampled in the Wah Wah Range on the west side of the basin (sites 1, 2, 3, and 20; fig. 10). 
Table 6. Measured field parameters and dissolved concentrations of major ions, nutrients, and selected metals for groundwater sampled from Pine and Wah Wah Valleys and surrounding areas, Utah.

[Sample identificaiton (ID): See figure 10 for locations and table 5 for additional site information. Values shown in red exceed the U.S. Environmental Protection Agency (EPA) maximum contaminant level or secondary standard. Abbreviations: USGS, U.S. Geological Survey; ${ }^{\circ} \mathrm{C}$, degrees Celsius; $\mu \mathrm{S} / \mathrm{cm}$, microsiemens per centimeter at $25 \mathrm{degrees} \mathrm{Celsius;} \mathrm{mg} / \mathrm{L}$, milligrams per liter; $\mu \mathrm{g} / \mathrm{L}$, micrograms per liter; E, estimated; - , no information; <, less than]

\begin{tabular}{|c|c|c|c|c|c|c|c|c|c|c|c|c|c|}
\hline $\begin{array}{l}\text { Sample } \\
\text { ID }\end{array}$ & USGS site number & $\begin{array}{c}\text { Water } \\
\text { temperature } \\
\left({ }^{\circ} \mathrm{C}\right)\end{array}$ & $\begin{array}{c}\text { Specific } \\
\text { conductance } \\
(\mu \mathrm{S} / \mathrm{cm})\end{array}$ & $\begin{array}{c}\mathrm{pH} \\
\text { (standard } \\
\text { units) }\end{array}$ & $\begin{array}{c}\text { Dissolved } \\
\text { oxygen } \\
\text { (mg/L) }\end{array}$ & $\begin{array}{l}\text { Dissolved } \\
\text { solids } \\
\text { (mg/L) } \\
\end{array}$ & $\begin{array}{c}\text { Alkalinity } \\
\text { (mg/L as } \\
\mathrm{CaCO}_{3} \text { ) }\end{array}$ & $\begin{array}{c}\text { Bicarbonate } \\
\text { (mg/L as } \\
\left.\mathrm{HCO}_{3}\right)\end{array}$ & $\begin{array}{c}\text { Bromide } \\
\text { (mg/L as } \\
\mathrm{Br})\end{array}$ & $\begin{array}{l}\text { Calcium } \\
\text { (mg/L as } \\
\text { Ca) }\end{array}$ & $\begin{array}{l}\text { Chloride } \\
\text { (mg/L as } \\
\text { CI) }\end{array}$ & $\begin{array}{l}\text { Fluoride } \\
\text { (mg/L as } \\
\text { F) }\end{array}$ & $\begin{array}{c}\text { Iron }(\mu \mathrm{g} / \mathrm{L} \\
\text { as Fe) }\end{array}$ \\
\hline 1 & 382901113295701 & 19.0 & 609 & 7.1 & 5.4 & 336 & 254 & 310 & 0.111 & 64.6 & 33.9 & 0.12 & 4.9 \\
\hline 2 & 382856113293301 & 17.5 & 613 & 7.3 & 3.7 & E 338 & 255 & 311 & E 0.041 & 64.3 & 34.0 & 0.12 & 148 \\
\hline 3 & 382344113305901 & 13.7 & 973 & 6.8 & 5.1 & 575 & 325 & 397 & 0.247 & 120 & 100 & 0.06 & 6.0 \\
\hline 4 & 382016113364001 & 9.3 & 566 & 6.9 & 5.3 & 336 & 291 & 355 & 0.017 & 104 & 11.0 & 0.11 & $<4.0$ \\
\hline 5 & 381045113470701 & 11.4 & 588 & 6.8 & 8.0 & E 345 & 239 & 292 & E 0.031 & 86.2 & 26.9 & 0.47 & $<4.0$ \\
\hline 6 & 382445113501401 & 11.6 & 1,390 & 6.9 & 1.8 & E 831 & 248 & 303 & E 0.750 & 132 & 231 & 0.11 & 21.4 \\
\hline 7 & 382550113504001 & 9.3 & 409 & 7.3 & 2.8 & Е 239 & 150 & 183 & E 0.078 & 43.3 & 29.7 & 0.11 & $<4.0$ \\
\hline 8 & 383131113214301 & 19.9 & 777 & 8.1 & 0.6 & E 432 & 92 & 112 & E 0.096 & 35.7 & 114 & 0.57 & 208 \\
\hline 9 & 383538113450801 & 16.6 & 284 & 7.7 & 7.5 & 205 & 115 & 141 & 0.050 & 19.1 & 8.4 & 1.1 & 4.0 \\
\hline 10 & 381344113512301 & 12.5 & 473 & 7.6 & 1.4 & 271 & 205 & 250 & 0.074 & 54.6 & 18.4 & 0.90 & 91.0 \\
\hline 11 & 383402113440601 & 19.5 & 307 & 8.3 & 6.0 & 234 & 103 & 126 & 0.075 & 20.0 & 19.9 & 0.83 & 19.4 \\
\hline 12 & 382259113433701 & 20.0 & 325 & 7.7 & - & 219 & 98.7 & 120 & 0.112 & 35.5 & 28.8 & 0.36 & 34.5 \\
\hline 13 & 381152113442801 & 16.7 & 498 & 7.3 & 5.9 & 316 & 153 & 187 & 0.205 & 61.4 & 50.3 & 0.42 & 95.4 \\
\hline 14 & 382539113250601 & 21.9 & 546 & 8.9 & 0.6 & 318 & 77 & 94 & 0.180 & 36.4 & 78.0 & 0.28 & 38.6 \\
\hline 15 & 382101113170801 & 14.6 & 632 & 7.3 & 6.8 & 387 & 105 & 128 & 0.230 & 58.1 & 106 & 0.41 & 25.5 \\
\hline 16 & 381957113163701 & 15.1 & 1,180 & 7.1 & 3.6 & 712 & 190 & 232 & 0.453 & 93.1 & 186 & 0.52 & 45.7 \\
\hline 17 & 382423113243601 & 23.7 & 583 & 7.6 & 6.0 & 391 & 113 & 138 & 0.138 & 42.9 & 56.5 & 0.42 & 48.2 \\
\hline 18 & 383825113410801 & 16.7 & 303 & 7.6 & - & 212 & 100 & 122 & - & 23 & 26 & - & - \\
\hline 19 & 384042113181601 & 16.2 & 2,120 & 7.6 & - & 1,290 & 129 & 157 & - & 51 & 614 & - & - \\
\hline 20 & 381848113292701 & 12.3 & 866 & 6.6 & - & 570 & 298 & 364 & - & 109 & 101 & - & - \\
\hline 21 & 382238113205301 & 18.6 & 622 & 7.9 & - & 448 & 108 & 132 & - & 54 & 125 & - & - \\
\hline 22 & 381702113383101 & 14.8 & 167 & 7.2 & - & 120 & 57.4 & 70 & - & 18 & 11 & - & - \\
\hline 23 & 382024113502101 & 15.4 & 525 & 7.6 & - & 340 & 197 & 240 & - & 49 & 36 & - & - \\
\hline 24 & 383452113572301 & 9.5 & 1,170 & 6.8 & - & 872 & 315 & 384 & - & 198 & 93 & - & - \\
\hline \multicolumn{14}{|c|}{ EPA maximum contaminant level (MCL) } \\
\hline- & - & - & - & - & - & - & - & - & - & - & - & - & - \\
\hline \multicolumn{14}{|c|}{ EPA secondary standard } \\
\hline- & - & - & - & - & - & 500 & - & - & - & - & 250 & 2 & 300 \\
\hline
\end{tabular}


Table 6. Measured field parameters and dissolved concentrations of major ions, nutrients, and selected metals for groundwater sampled from Pine and Wah Wah Valleys and surrounding areas, Utah.-Continued

[Sample identificaiton (ID): See figure 10 for locations and table 5 for additional site information. Values shown in red exceed the U.S. Environmental Protection Agency (EPA) maximum contaminant level or secondary standard. Abbreviations: USGS, U.S. Geological Survey; ${ }^{\circ} \mathrm{C}$, degrees Celsius; $\mu \mathrm{S} / \mathrm{cm}$, microsiemens per centimeter at $25 \mathrm{degrees}$ Celsius; $\mathrm{mg} / \mathrm{L}$, milligrams per liter; $\mu \mathrm{g} / \mathrm{L}$, micrograms per liter; E, estimated; - , no information; <, less than]

\begin{tabular}{|c|c|c|c|c|c|c|c|c|c|c|c|c|c|}
\hline $\begin{array}{l}\text { Sample } \\
\text { ID }\end{array}$ & USGS site number & $\begin{array}{c}\text { Magnesium } \\
\text { (mg/L as } \\
\mathrm{Mg})\end{array}$ & $\begin{array}{c}\text { Manganese } \\
(\mu \mathrm{g} / \mathrm{L} \text { as } \\
\mathrm{Mn})\end{array}$ & $\begin{array}{c}\text { Potassium } \\
\text { (mg/L as } \\
\mathrm{K})\end{array}$ & $\begin{array}{c}\text { Silica } \\
\text { (mg/L as } \\
\mathrm{SiO}_{2} \text { ) }\end{array}$ & $\begin{array}{l}\text { Sodium } \\
\text { (mg/L as } \\
\mathrm{Na} \text { ) }\end{array}$ & $\begin{array}{c}\text { Sulfate } \\
\text { (mg/L as } \\
\mathrm{SO}_{4} \text { ) }\end{array}$ & $\begin{array}{c}\text { Nitrate } \\
\text { plus nitrite } \\
\text { (mg/L as N) }\end{array}$ & $\begin{array}{c}\text { Ortho- } \\
\text { phophate } \\
\text { (mg/L as P) }\end{array}$ & $\begin{array}{c}\text { Arsenic } \\
\text { ( } \mu \mathrm{g} / \mathrm{L} \text { as } \\
\text { As) }\end{array}$ & $\begin{array}{c}\text { Molybdenum } \\
\text { ( } \mu \mathrm{g} / \mathrm{L} \text { as } \\
\text { Mo) }\end{array}$ & $\begin{array}{c}\text { Selenium } \\
\text { ( } \mu \mathrm{g} / \mathrm{L} \text { as } \\
\mathrm{Se})\end{array}$ & $\begin{array}{c}\text { Uranium } \\
\text { ( } \mu \mathrm{g} / \mathrm{L} \text { as } \\
\text { U) }\end{array}$ \\
\hline 1 & 382901113295701 & 30.3 & $<0.16$ & 1.20 & 13.0 & 19.5 & 14.2 & 1.49 & 0.006 & 1.4 & 0.253 & 0.67 & 1.1 \\
\hline 2 & 382856113293301 & 30.9 & 8.04 & 1.23 & 14.2 & 19.7 & 14.1 & 1.49 & 0.006 & 1.1 & 0.237 & 0.59 & 1.2 \\
\hline 3 & 382344113305901 & 39.0 & $<0.16$ & 1.45 & 38.8 & 32.5 & 37.1 & 2.45 & 0.026 & 2.4 & 0.378 & 1.4 & 10 \\
\hline 4 & 382016113364001 & 13.5 & 0.20 & 0.60 & 12.6 & 9.83 & 10.6 & $<0.040$ & 0.005 & 0.32 & 0.209 & 0.27 & 1.61 \\
\hline 5 & 381045113470701 & 14.3 & $<0.16$ & 1.57 & 19.7 & 23.8 & 27.6 & 0.152 & 0.014 & 0.49 & 1.06 & 0.37 & 5.7 \\
\hline 6 & 382445113501401 & 52.7 & 55.4 & 1.09 & 45.0 & 82.1 & 138 & $<0.040$ & 0.018 & 3.8 & 0.970 & 1.9 & 21 \\
\hline 7 & 382550113504001 & 18.1 & 0.25 & 1.66 & 14.1 & 18.2 & 16.0 & 1.79 & 0.037 & 2.7 & 0.572 & 0.58 & 0.75 \\
\hline 8 & 383131113214301 & 18.8 & 9.87 & 12.4 & 26.2 & 74.4 & 92.5 & 0.238 & 0.016 & 6.7 & 4.16 & 0.53 & 1.3 \\
\hline 9 & 383538113450801 & 7.87 & $<0.16$ & 5.21 & 47.4 & 28.1 & 11.8 & 1.53 & 0.023 & 46 & 2.87 & 0.50 & 5.0 \\
\hline 10 & 381344113512301 & 17.2 & 18.9 & 1.31 & 13.8 & 20.7 & 15.9 & 0.374 & $<0.004$ & 0.46 & 0.733 & 1.6 & 18 \\
\hline 11 & 383402113440601 & 5.14 & 4.73 & 6.70 & 55.7 & 32.5 & 13.8 & 1.42 & 0.045 & 20 & 3.34 & 0.71 & 1.7 \\
\hline 12 & 382259113433701 & 6.50 & 8.98 & 2.61 & 23.6 & 24.6 & 19.7 & 0.898 & 0.006 & 2.7 & 1.37 & 0.74 & 3.2 \\
\hline 13 & 381152113442801 & 8.50 & 41.1 & 4.14 & 48.9 & 25.6 & 19.8 & 0.498 & 0.015 & 2.1 & 1.10 & 0.95 & 7.7 \\
\hline 14 & 382539113250601 & 12.5 & 63.8 & 6.22 & 21.3 & 46.4 & 59.4 & 0.298 & 0.029 & 3.6 & 4.52 & 0.41 & 0.31 \\
\hline 15 & 382101113170801 & 16.2 & 16 & 4.65 & 41.4 & 36.9 & 21.2 & 5.96 & 0.019 & 3.9 & 1.54 & 1.1 & 2.3 \\
\hline 16 & 381957113163701 & 27.8 & 3.59 & 3.62 & 28.1 & 109 & 130 & 2.24 & 0.021 & 35 & 1.90 & 5.7 & 9.2 \\
\hline 17 & 382423113243601 & 18.1 & 10.3 & 9.02 & 57.6 & 40.9 & 66.7 & 1.75 & 0.017 & 4.0 & 1.65 & 0.89 & 3.6 \\
\hline 18 & 383825113410801 & 14.5 & - & 3.81 & - & 30 & 48.2 & 1.86 & - & - & - & - & - \\
\hline 19 & 384042113181601 & 39.1 & - & 14.4 & - & 372 & 167 & 2.41 & - & - & - & - & - \\
\hline 20 & 381848113292701 & 28.5 & - & 1.17 & - & 60 & 69.8 & 0.01 & - & - & - & - & - \\
\hline 21 & 382238113205301 & 19.9 & - & 4.42 & - & 51 & 40.6 & 0.99 & - & - & - & - & - \\
\hline 22 & 381702113383101 & 4.20 & - & 0.83 & - & 8.0 & 4 & $<0.5$ & - & - & - & - & - \\
\hline 23 & 382024113502101 & 4.40 & - & 2.30 & - & 53 & 15 & 3.1 & - & - & - & - & - \\
\hline 24 & 383452113572301 & 46.4 & - & 4.23 & - & 48 & 334 & 0.06 & - & - & - & - & - \\
\hline \multicolumn{14}{|c|}{ EPA maximum contaminant level (MCL) } \\
\hline - & - & - & - & - & - & - & - & - & - & 10 & - & 50 & 30 \\
\hline \multicolumn{14}{|c|}{ EPA secondary standard } \\
\hline- & - & - & 50 & - & - & - & 250 & 10 & - & - & - & - & - \\
\hline
\end{tabular}




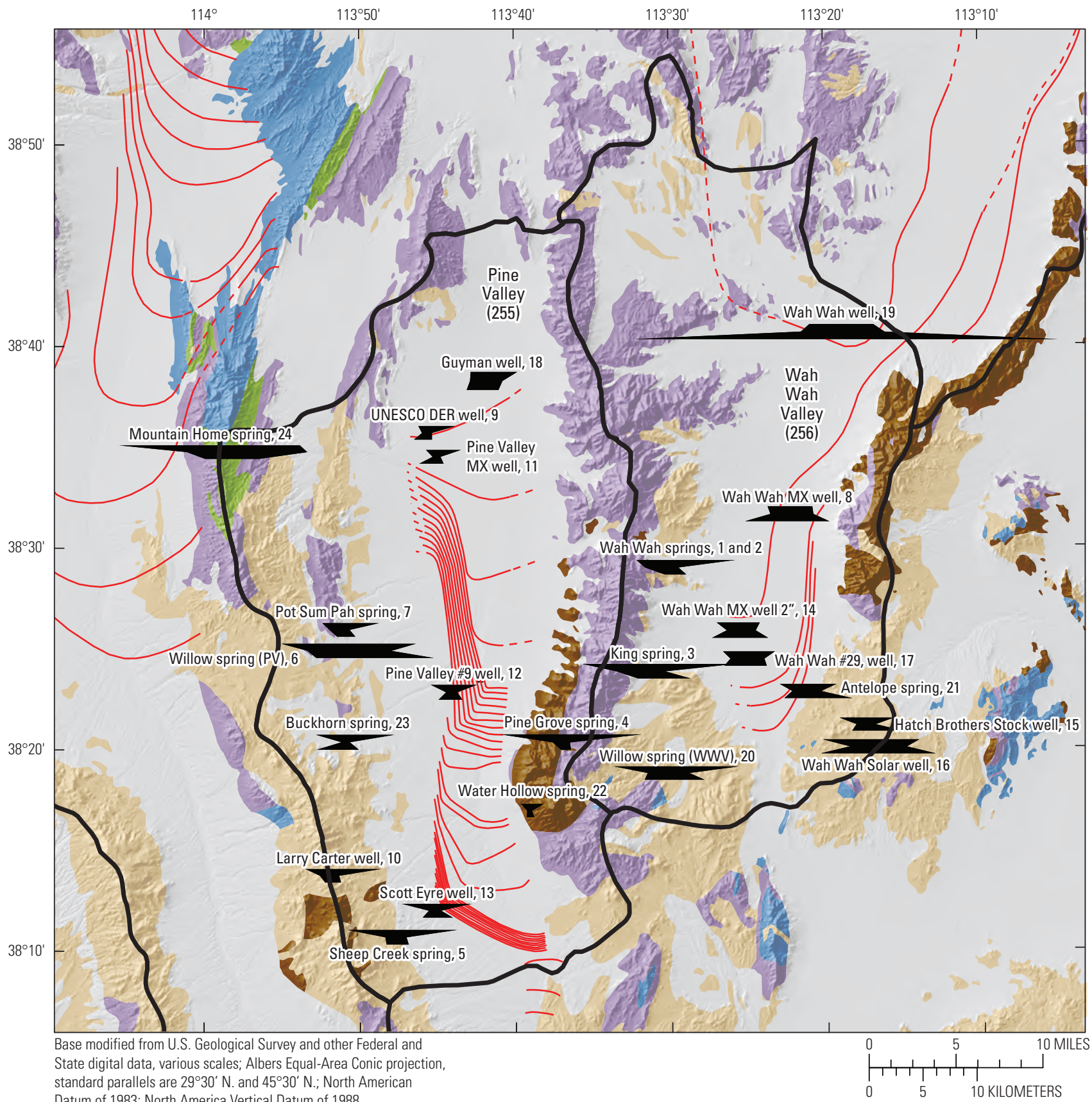

Datum of 1983: North America Vertical Datum of 1988

EXPLANATION

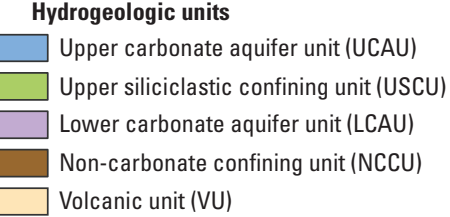

Hydrogeologic units

Upper carbonate aquifer unit (UCAU)

Upper siliciclastic confining unit (USCU)

Non-carbonate confining unit (NCCU)
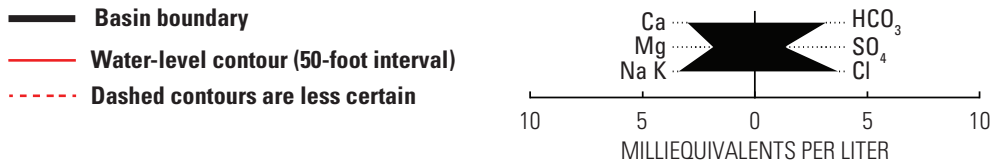

Stiff diagrams show sample site location and identification numbers

The relative size of the stiff diagrams indicate the relative dissolved solids concentrations of the sample

Figure 10. Locations of groundwater sample sites and corresponding stiff diagrams showing major-ion composition of groundwater in Pine and Wah Wah Valleys, Utah. 


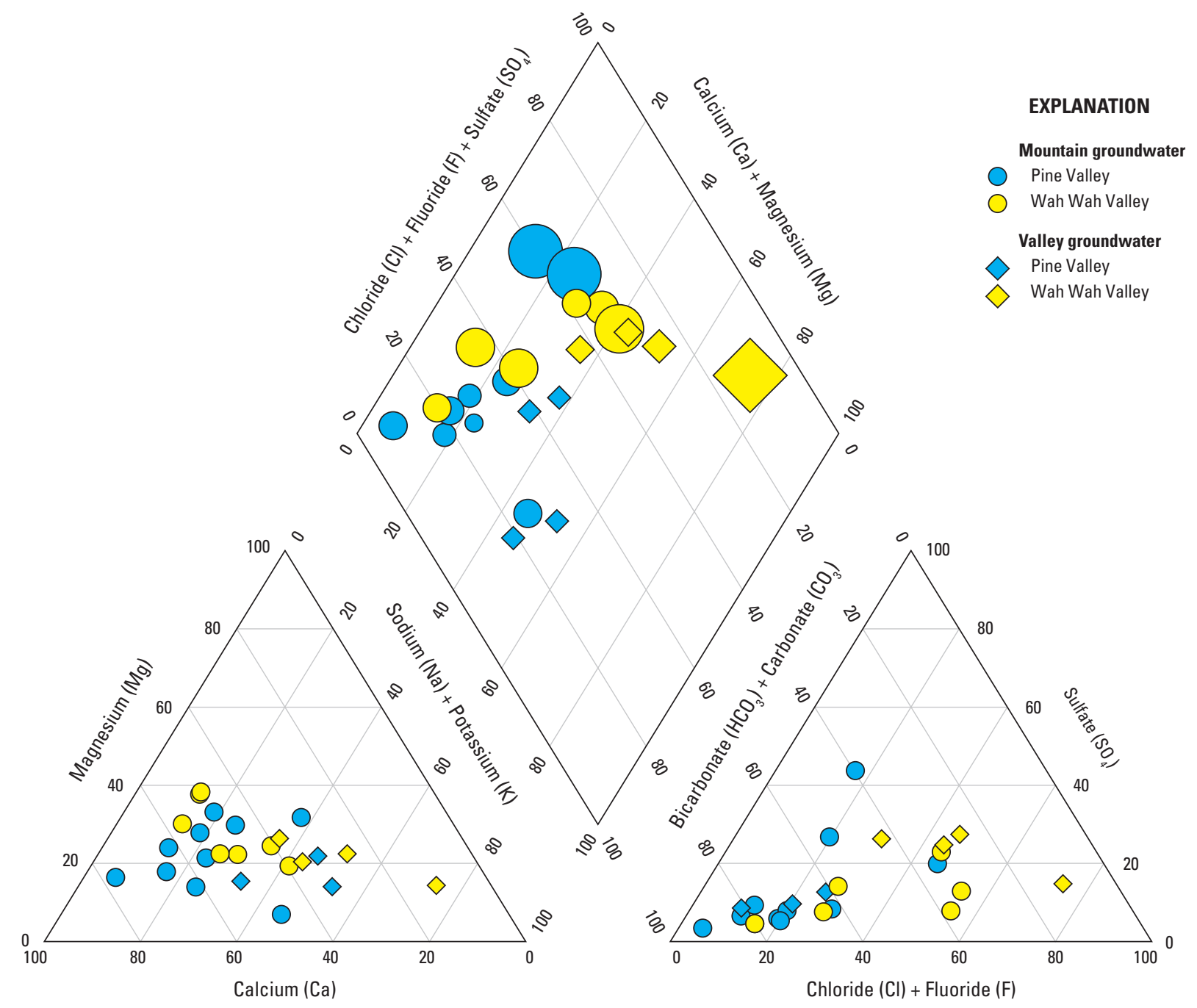

Figure 11. Major-ion composition of groundwater in Pine and Wah Wah Valleys and surrounding areas, Utah. The size of the symbol in the upper diamond represents the relative dissolved-solids concentration of the sample.

\section{Tritium and Helium}

Groundwater ${ }^{3} \mathrm{H}$ concentrations ranged from below detection (about $0.1 \mathrm{TU}$ ) to $5.2 \mathrm{TU}$ (table 7). Terrigenic helium- 4 concentrations ranged from not detected to $4.14 \times 10^{-7} \mathrm{ccSTP} / \mathrm{g}$ and $\mathrm{R} / \mathrm{R}_{\mathrm{a}}$ values ranged from 0.15 to 1.05 for the 19 samples where dissolved noble gases were measured. The combined analysis of tritium and helium clearly identifies a component of "modern" water (less than about 60 years old) at 11 of the 24 sites sampled (sites 1-7, $10,20,22$, and 24). All of these sites are in the mountains surrounding the valleys (PV-mountain and WW-mountain groundwater). The high end of the ${ }^{4} \mathrm{He}_{\text {terr }}$ concentrations and low end of the $R / R_{a}$ values indicate that many of the samples contain water that is too old to be dated using ${ }^{3} \mathrm{H}$. Some mountain samples appear to be pre-modern (more than 60 years old) or mixtures of modern and pre-modern water based on tritium and helium concentrations (sample identifications [IDs] 3, 10, 13, 15, 16, 21, 23, and 24), indicating areas of mountain residence times of 60 years or more. None of the valley samples (sample IDs 8, 9, 11, 12, $14,17,18$, and 19; PV-valley and WW-valley groundwater) contained even a fraction of modern water (table 7).

Ratios of ${ }^{3} \mathrm{H}$ to ${ }^{3} \mathrm{He}_{\text {trit }}$ were used to calculate apparent ages of groundwater discharging from six mountain springs (sites 1 , 2, and 4-7; table 7). Samples from Wah Wah Spring (sample IDs 1 and 2) had apparent ${ }^{3} \mathrm{H} /{ }^{3} \mathrm{He}_{\text {trit }}$ ages of 27 and 29 years, respectively. Samples from sites 4-7, which are springs in the mountains surrounding Pine Valley, had apparent ${ }^{3} \mathrm{H} /{ }^{3} \mathrm{He}_{\text {trit }}$ ages of 1-21 years. The remaining groundwater samples could not be dated by this method, either because they contained too little ${ }^{3} \mathrm{H}$ or because of complications owing to elevated ${ }^{4} \mathrm{He}_{\text {terr }}$. 
Table 7. Stable- and radio-isotope data used to estimate ages of groundwater sampled from Pine and Wah Wah Valleys, Utah.

[Sample identification (ID): See figure 10 for locations. Pre-modern, groundwater that recharged prior to the mid-1950s. Modern, groundwater that recharged after the mid-1950s. Mixture is a sample that contains a mixture of pre-modern and modern groundwater. Abbreviations: USGS, U.S. Geological Survey; $\delta^{18} \mathrm{O}$, oxygen-18; permil, per million; D, deuterium; ${ }^{3} \mathrm{H}$, tritium; TU, tritium units; ${ }^{4} \mathrm{He}$, measured helium-4; ccSTP/g, cubic centimeters per gram of water at standard temperature and pressure; ${ }^{4} \mathrm{He}_{\text {terr }}$, terrigenic helium-4; ${ }^{3} \mathrm{He}_{\text {trit }}$, tritiogenic helium-3, ${ }^{3} \mathrm{H} /{ }^{3} \mathrm{He}$ trit, tritium/tritiogenic helium-3; $\mathrm{BP}$, before present; ${ }^{14} \mathrm{C}$, Carbon-14; pmC, percent modern carbon; ${ }^{13} \mathrm{C}$, carbon-13; F\&G, Fontes and Garnier (1979) model; $+/-$, plus or minus; -, no information; ND, not detected; <, less than]

\begin{tabular}{|c|c|c|c|c|c|c|c|c|c|c|c|c|c|c|c|}
\hline $\begin{array}{l}\text { Sample } \\
\text { ID }\end{array}$ & USGS site number & $\begin{array}{c}\delta^{18} 0 \\
\text { (permil) }\end{array}$ & $\begin{array}{c}\delta D \\
\text { (permil) }\end{array}$ & $\begin{array}{c}{ }^{3} \mathrm{H} \text { and } \\
\text { precision (TU) }\end{array}$ & $\mathbf{R} / \mathbf{R} \mathbf{a}^{1}$ & $\begin{array}{c}{ }^{4} \mathrm{He} \\
\text { (ccSTP/g) }\end{array}$ & $\begin{array}{c}{ }^{4} \mathrm{He}_{\text {terr }}{ }^{2} \\
\text { (ccSTP/g) }\end{array}$ & $\begin{array}{l}{ }^{3} \mathrm{He}_{\text {trit }}{ }^{2} \\
\text { (TU) }\end{array}$ & $\begin{array}{c}\text { Apparent } \\
{ }^{3} \mathrm{H}^{3} \mathrm{He}_{\text {trit }} \text { age } \\
\text { (years BP) }\end{array}$ & $\begin{array}{c}{ }^{14} \mathrm{C} \\
(\mathrm{pmC})\end{array}$ & $\begin{array}{c}\delta^{13} \mathbf{C} \\
\text { (permil) }\end{array}$ & $\begin{array}{l}\text { Unadjusted }{ }^{14} \mathrm{C} \\
\text { age (thousands } \\
\text { of years BP) }\end{array}$ & $\begin{array}{c}{ }^{14} \mathrm{C} \text { age } \mathrm{F} \& \mathrm{G} \\
\text { (years } \mathrm{BP} \text { ) }\end{array}$ & $\begin{array}{c}\text { Calibrated } \\
\text { age (years } \\
\text { BP) } \\
\end{array}$ & $\begin{array}{c}\text { Age } \\
\text { category }\end{array}$ \\
\hline 1 & 382901113295701 & -14.5 & -109 & $0.6+/-0.2$ & 1.00 & $4.47 \mathrm{E}-08$ & $3.74 \mathrm{E}-09$ & 2.0 & 27 & 39 & -8.7 & 8,000 & 100 & - & Mixture $^{4}$ \\
\hline 2 & 382856113293301 & -14.4 & -110 & $0.5+/-0.2$ & 1.00 & $4.39 \mathrm{E}-08$ & $3.61 \mathrm{E}-09$ & 2.0 & 29 & 38 & -8.5 & 8,000 & 40 & - & Mixture $^{4}$ \\
\hline 3 & 382344113305901 & -12.6 & -100 & $0.7+/-0.1$ & 0.75 & $6.24 \mathrm{E}-08$ & $1.93 \mathrm{E}-08$ & 1.8 & Mixture & 97 & -11.6 & 300 & Mixture & - & Mixture $^{4}$ \\
\hline 4 & 382016113364001 & -14.2 & -106 & $5.2+/-0.3$ & 1.00 & $4.01 \mathrm{E}-08$ & $4.02 \mathrm{E}-09$ & 2.2 & 6.3 & 99 & -12.1 & Modern & Modern & - & Modern \\
\hline 5 & 381045113470701 & -13.2 & -99.2 & $3.6+/-0.3$ & 1.00 & $4.27 \mathrm{E}-08$ & ND & 0.0 & $<1$ & 103 & -12.6 & Modern & Modern & - & Modern \\
\hline 6 & 382445113501401 & -12.3 & -99.0 & $0.8+/-0.1$ & 0.98 & $4.21 \mathrm{E}-08$ & 4.15E-09 & 1.7 & 21 & 107 & -9.9 & Modern & Modern & - & Modern \\
\hline 7 & 382550113504001 & -13.7 & -104 & $2.6+/-0.2$ & 1.05 & $4.13 \mathrm{E}-08$ & $5.17 \mathrm{E}-09$ & 4.0 & 17 & 61 & -9.9 & 4,000 & Modern & - & Modern \\
\hline 8 & 383131113214301 & -14.7 & -110 & $-0.1+/-0.1$ & 0.37 & $1.39 \mathrm{E}-07$ & $1.06 \mathrm{E}-07$ & - & Pre-modern & 3.2 & -5.6 & 28,000 & 16,000 & $19,000 \quad \mathrm{I}$ & Pleistocene \\
\hline 9 & 383538113450801 & -14.7 & -112 & $0.3+/-0.1$ & 0.39 & $1.15 \mathrm{E}-07$ & $7.61 \mathrm{E}-08$ & - & Pre-modern & 17 & -7.8 & 14,000 & 6,000 & 7,000 & Holocene \\
\hline 10 & 381344113512301 & -13.5 & -102 & $1.5+/-0.1$ & 0.23 & $5.23 \mathrm{E}-07$ & $4.14 \mathrm{E}-07$ & - & Mixture & 83 & -11.8 & 2,000 & Mixture & - & Mixture $^{4}$ \\
\hline 11 & 383402113440601 & -14.4 & -109 & $-0.01+/-0.2$ & 0.57 & $1.48 \mathrm{E}-07$ & $5.94 \mathrm{E}-08$ & - & Pre-modern & 10 & -6.8 & 19,000 & 9,000 & 10,000 & Holocene \\
\hline 12 & 382259113433701 & -13.8 & -105 & $0.03+/-0.1$ & 0.43 & $2.47 \mathrm{E}-07$ & $2.09 \mathrm{E}-07$ & - & Pre-modern & 36 & -9.8 & 8,000 & 2,000 & 2,000 & Holocene \\
\hline 13 & 381152113442801 & -13.5 & -102 & $0.05+/-0.1$ & 0.15 & $2.35 \mathrm{E}-07$ & $1.99 \mathrm{E}-07$ & - & Pre-modern & 62 & -11.1 & & Pre-modern & - & $\begin{array}{c}\text { Late } \\
\text { Holocene }\end{array}$ \\
\hline 14 & 382539113250601 & -13.2 & -102 & $0.02+/-0.1$ & 0.72 & $6.66 \mathrm{E}-08$ & - & - & Pre-modern & 48 & -5.6 & 6,000 & Pre-modern & 一 & $\begin{array}{c}\text { Late } \\
\text { Holocene }\end{array}$ \\
\hline 15 & 382101113170801 & -13.5 & -103 & $0.01+/-0.1$ & 0.84 & $4.81 \mathrm{E}-08$ & $1.73 \mathrm{E}-08$ & 11.2 & Pre-modern & 60 & -7.1 & 3,000 & Pre-modern & - & $\begin{array}{c}\text { Late } \\
\text { Holocene }\end{array}$ \\
\hline 16 & 381957113163701 & -13.5 & -107 & $0.01+/-0.1$ & 0.30 & $1.60 \mathrm{E}-07$ & $1.24 \mathrm{E}-07$ & - & Pre-modern & 37 & -7.9 & 8,000 & Pre-modern & - & Holocene \\
\hline 17 & 382423113243601 & -13.5 & -103 & $0.04+/-0.1$ & 0.25 & $1.70 \mathrm{E}-07$ & $1.32 \mathrm{E}-07$ & - & Pre-modern & 45 & -8.4 & 6,000 & Pre-modern & - & $\begin{array}{c}\text { Late } \\
\text { Holocene }\end{array}$ \\
\hline 18 & 383825113410801 & -13.8 & -105 & $0.1+/-0.1$ & 0.49 & $7.95 \mathrm{E}-08$ & $4.04 \mathrm{E}-08$ & - & Pre-modern & 11 & -9.6 & 18,000 & 11,000 & 13,000 & Pleistocene \\
\hline 19 & 384042113181601 & -14.1 & -106 & $0.1+/-0.1$ & 0.43 & $9.83 \mathrm{E}-08$ & $7.48 \mathrm{E}-08$ & - & Pre-modern & 7.4 & -9.2 & 21,000 & 14,000 & 17,000 & Pleistocene \\
\hline 20 & 381848113292701 & -13.1 & -102 & $5.2+/-0.2$ & - & - & - & - & Modern & 104 & -11.9 & Modern & Modern & - & Modern \\
\hline 21 & 382238113205301 & -12.7 & -113 & $0.1+/-0.1$ & - & - & - & - & Pre-modern & 54 & -12.2 & 5,000 & 500 & - & $\begin{array}{c}\text { Late } \\
\text { Holocene }\end{array}$ \\
\hline 22 & 381702113383101 & -14.8 & -104 & $4.6+/-0.2$ & - & - & - & - & Modern & 106 & -13.0 & Modern & Modern & - & Modern \\
\hline 23 & 382024113502101 & -14.2 & -105 & $0.1+/-0.1$ & - & - & - & - & Pre-modern & 75 & -7.9 & 2,000 & Pre-modern & - & $\begin{array}{c}\text { Late } \\
\text { Holocene }\end{array}$ \\
\hline 24 & 383452113572301 & -14.6 & -111 & $1.6+/-0.1$ & - & - & - & - & $\begin{array}{l}\text { Modern or } \\
\text { Mixture }\end{array}$ & 49 & -9.9 & 6,000 & Mixed & - & Mixture $^{4}$ \\
\hline
\end{tabular}

${ }^{1} \mathrm{R}$ is the ${ }^{3} \mathrm{He} /{ }^{4} \mathrm{He}$ ratio of the sample, and $\mathrm{Ra}$ is the ${ }^{3} \mathrm{He} /{ }^{4} \mathrm{He}$ ratio of air $\left(1.384 \times 10^{-6}\right)$.

2Interpreted value derived using the closed-equilibrium dissolved-gas model (Aeschbach-Hertig and others, 2000; Kipfer and others, 2002).

${ }^{3}$ Radiocarbon ages calibrated using the program CALIB (Stuiver and others, 2005) with the IntCal13 radiocalibration curve (Reimer and others, 2013).

${ }^{4}$ Water samples categorized as mixed are dominantly mixtures of modern and Late Holocene groundwater. 


\section{Carbon-14 and Age Categories}

Carbon-14 activity measured from dissolved inorganic carbon (DIC) in groundwater samples ranged from 3.2 to $107 \mathrm{pmC}$ (table 7). A clear distinction is seen in ${ }^{14} \mathrm{C}$ activities between mountain and valley groundwaters. Pine Valleymountain groundwater (sample IDs 4, 5, 6, 7, 10, 13, 22, 23, and 24) ranged from 49 to $107 \mathrm{pmC}$ and WW-mountain groundwater (sample IDs 1, 2, 3, 15, 16, 20, and 21) ranged from 37 to $104 \mathrm{pmC}$, whereas PV-valley groundwater (sample IDs 9, 11, 12, and 18) ranged from 10 to $36 \mathrm{pmC}$ and WW-valley groundwater (sample IDs $8,14,17$, and 19) ranged from 3.2 to $48 \mathrm{pmC}$.

Adjusted and calibrated radiocarbon ages were calculated for the six samples with the lowest ${ }^{14} \mathrm{C}$ activities (sample IDs $8,9,11,12,18$, and 19) and ranged from 2,000 to 19,000 years BP. These six sites are either PV-valley or WW-valley groundwaters. The remaining two valley samples (sites 14 and 17 , WW-valley groundwater) yielded unreasonable (negative) adjusted radiocarbon ages indicating that they are too young to be reliably dated using ${ }^{14} \mathrm{C}$. The combination of low ${ }^{14} \mathrm{C}$ activity, lack of ${ }^{3} \mathrm{H}$, and elevated ${ }^{4} \mathrm{He}_{\text {terr }}$ in these two samples clearly indicate that they are pre-modern and possibly as old as several thousand years (table 7). Samples from Wah Wah Springs (sites 1 and 2) have adjusted radiocarbon ages of 100- and 40-years BP, respectively. However, given that the uncertainty of radiocarbon dates in these carbonate waters is as much as several thousand years, these ages are merely evidence that these samples contained a fraction of premodern water. Reliable adjusted radiocarbon ages could not be calculated for the remaining 14 samples (all PV-mountain and WW-mountain groundwaters), indicating that they are all modern, pre-modern, or mixed waters no more than about 2,000 years old.

Despite only being able to calculate ages (either ${ }^{3} \mathrm{H} /{ }^{3} \mathrm{He}$ or ${ }^{14} \mathrm{C}$ based) of groundwater for half of the sample sites, general age categories were assigned to all 24 samples based on evaluation of ${ }^{3} \mathrm{H}$, He-isotope, and ${ }^{14} \mathrm{C}$ data (table 7). This categorization is modified from that presented by Gardner and
Heilweil (2014) recognizing that significant variability can exist in isotope concentrations caused by mixing dynamics, variable crustal He production rates, and variable degrees of carbonate chemical reactions. Groundwater samples were categorized as one of the following:

(1) Modern (post-1950s),

(2) Mixture (modern and Late Holocene),

(3) Late Holocene (more than 60 and less than about 2,000 years),

(4) Holocene (more than 2,000 and less than about 11,700 years), and

(5) Pleistocene (more than about 11,700 years).

The criteria used to categorize the samples are summarized in table 8 .

All modern and mixed groundwater is found in the mountains surrounding the valleys (sample IDs $1-7,10$, 20, 22, and 24; table 7; fig. 12). Four mountain samples were categorized as Late Holocene (sample IDs 13 and 23, PV-mountain groundwater; and sample IDs 15 and 21, WW-mountain groundwater) and one as Holocene (sample ID 16, WW-mountain groundwater). All five of these sites discharge from volcanic bedrock or alluvium eroded from volcanic rocks in the hills and mountains bordering the valleys. The presence of water this old in the mountains indicates that these are areas of low bedrock permeability, that they receive little recharge, or both. No modern groundwater or mixtures containing modern water were reported in valley wells in either valley. Samples representing PV-valley groundwater were either Holocene (sample IDs 9, 11, and 12) or Pleistocene (site 18). Samples representing WW-valley groundwater were either Late Holocene (sample IDs 14 and 17) or Pleistocene (sample IDs 8 and 19). The groundwater ages in both basins display expected patterns with the youngest samples being from high-altitude mountain sites and valley groundwater increasing in age in a downgradient direction (generally south to north; table 7; fig. 12).

Table 8. Criteria used to assign age categories to groundwater samples from Pine and Wah Wah Valleys, Utah.

$\left[{ }^{3} \mathrm{H}\right.$, tritium; TU, tritium unit; ${ }^{4} \mathrm{He} e_{\text {terr }}$, terrigenic helium-4; ccSTP/g, cubic centimeters at standard temperature and pressure per gram of water; ${ }^{14} \mathrm{C}$, carbon-14; pmC, percent modern carbon; >, greater than; $<$, less than]

\begin{tabular}{|c|c|}
\hline Groundwater age category & Criteria \\
\hline Modern (post-1950s) & $\begin{array}{l}{ }^{3} \mathrm{H} \text { greater than } 0.4 \mathrm{TU} \text {, no significant }{ }^{4} \mathrm{He}_{\text {terr }} \text { (less than about } 1 \times 10^{-8} \mathrm{ccSTP} / \mathrm{g} \text { ), and }{ }^{14} \mathrm{C} \text { greater than } \\
\text { about } 60 \mathrm{pmC} \text {. }\end{array}$ \\
\hline Late Holocene ( $>60$ and $<2,000$ years) & $\begin{array}{l}{ }^{3} \mathrm{H} \text { less than } 0.4 \mathrm{TU} \text {, elevated }{ }^{4} \mathrm{He}_{\text {terr }} \text { (more than about } 1 \times 10^{-8} \mathrm{ccSTP} / \mathrm{g} \text { ), and carbon isotope data } \\
\text { suggesting ages of less than about } 2,000 \text { years. }\end{array}$ \\
\hline Pleistocene ( $>11,700$ years $)$ & $\begin{array}{l}{ }^{3} \mathrm{H} \text { less than } 0.4 \mathrm{TU} \text {, elevated }{ }^{4} \mathrm{He}_{\text {terr }} \text { (more than about } 4 \times 10^{-8} \mathrm{ccSTP} / \mathrm{g} \text { ), and carbon isotope data } \\
\text { suggesting ages of more than about } 11,700 \text { years. }\end{array}$ \\
\hline
\end{tabular}




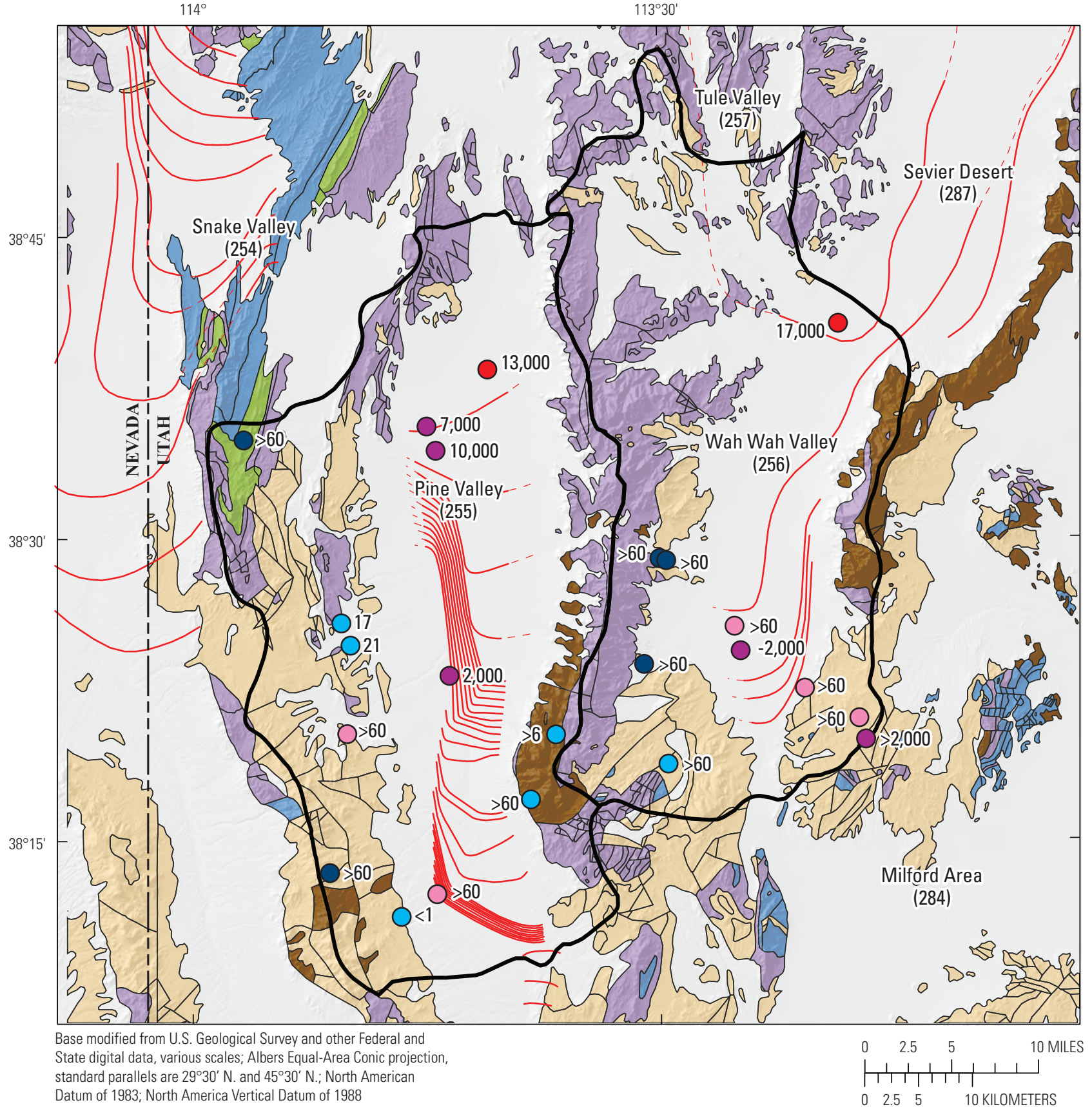

Hydrogeologic units

Upper carbonate aquifer unit (UCAU)

Upper Siliciclastic confining unit (USCU)

Lower carbonate aquifer unit (LCAU)

Non-carbonate confining unit (NCCU)

Volcanic unit (VU)
EXPLANATION

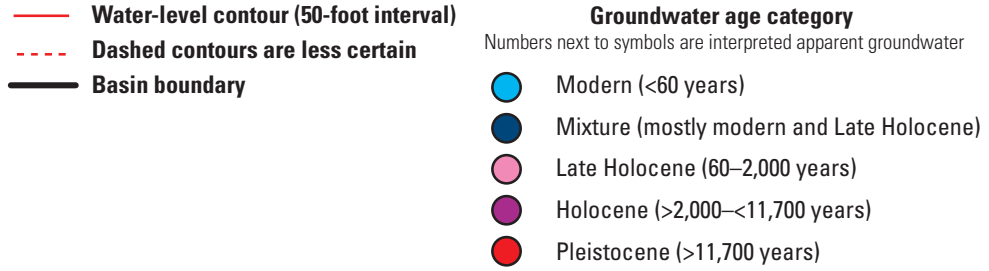

Figure 12. Groundwater-age categories and apparent groundwater ages based on multiple age-related environmental tracers for selected groundwater samples from Pine and Wah Wah Valleys, Utah. 


\section{Oxygen-18 and Deuterium}

Stable-isotope compositions for the groundwater sampled from Pine and Wah Wah Valley drainage basins ranged from -14.8 to -12.3 permil and from -113 to -102 permil for $\delta^{18} \mathrm{O}$ and $\delta \mathrm{D}$, respectively (table 7). All waters plot near the Utah or Global Meteoric Water Line except for Antelope Spring (site 21) in the southeast foothills of Wah Wah Valley (fig. 13). This sample was preferentially enriched in $\delta^{18} \mathrm{O}$ relative to $\delta \mathrm{D}$ because of evaporation, which is not surprising because this is a diffuse discharge spring that feeds a large, nearly stagnant pool. There were no significant differences between samples collected from Pine or Wah Wah Valleys or between samples collected from mountain or valley locations; all of the groups had a similar range in measured $\delta \mathrm{D}$ and $\delta^{18} \mathrm{O}$ compositions.

Samples sourced from precipitation falling at higher altitudes or during the winter months will be isotopically lighter (more negative values) and plot lower and farther to the left along a meteoric water line, whereas samples sourced from precipitation falling at lower altitudes or during the summer months should be isotopically heavier (fewer negative values) and plot higher and farther to the right (fig. 13). When compared to 135 groundwater samples from 7 neighboring or nearby basins, Pine and Wah Wah Valley groundwaters were isotopically heavier than many of them. A subset (16) of eastern Great Basin mountain springs with modern ${ }^{3} \mathrm{H}-{ }^{3} \mathrm{He}$ ages defines a zone of modern mountain precipitation that generally aligns with the range of $\delta^{2} \mathrm{H}$ values for modern cumulative winter precipitation ( -120 to -110 permil) in these valleys presented by Friedman and others (2002) indicating that much of the geographic region is recharged by highaltitude winter precipitation. This recharge occurs as snow melt and either infiltrates in the mountains or generates runoff that infiltrates basin-fill aquifers near the mountain front. Twenty-one of 24 samples from Pine and Wah Wah Valleys were isotopically heavier than cumulative winter precipitation, clearly falling in the $\delta^{2} \mathrm{H}$ range of cumulative annual precipitation and indicating that winter rain and melting snow is not the dominant source of recharge in Pine and Wah Wah Valleys.

\section{Noble Gas- and Water-Table Temperatures}

Because NGTs represent estimates of recharge temperature (the water-table temperature at the location of recharge), they can be compared to valley water-table temperatures to evaluate whether samples represent mountain or valley recharge. In many parts of the eastern Great Basin, mountain water-table temperatures are notably cooler than valley water-table temperatures, providing a clear contrast between the two (Gardner and Heilweil, 2014). And because of the conservative nature of dissolved noble gases in saturated freshwater systems, NGTs can be used to identify continuous groundwater flow between recharge and sample locations. For example, if samples collected from valley wells have NGTs that are clearly cooler than valley water-table temperatures, then they likely originated as mountain recharge and moved into the valley aquifer through the subsurface along a continuous flow path.
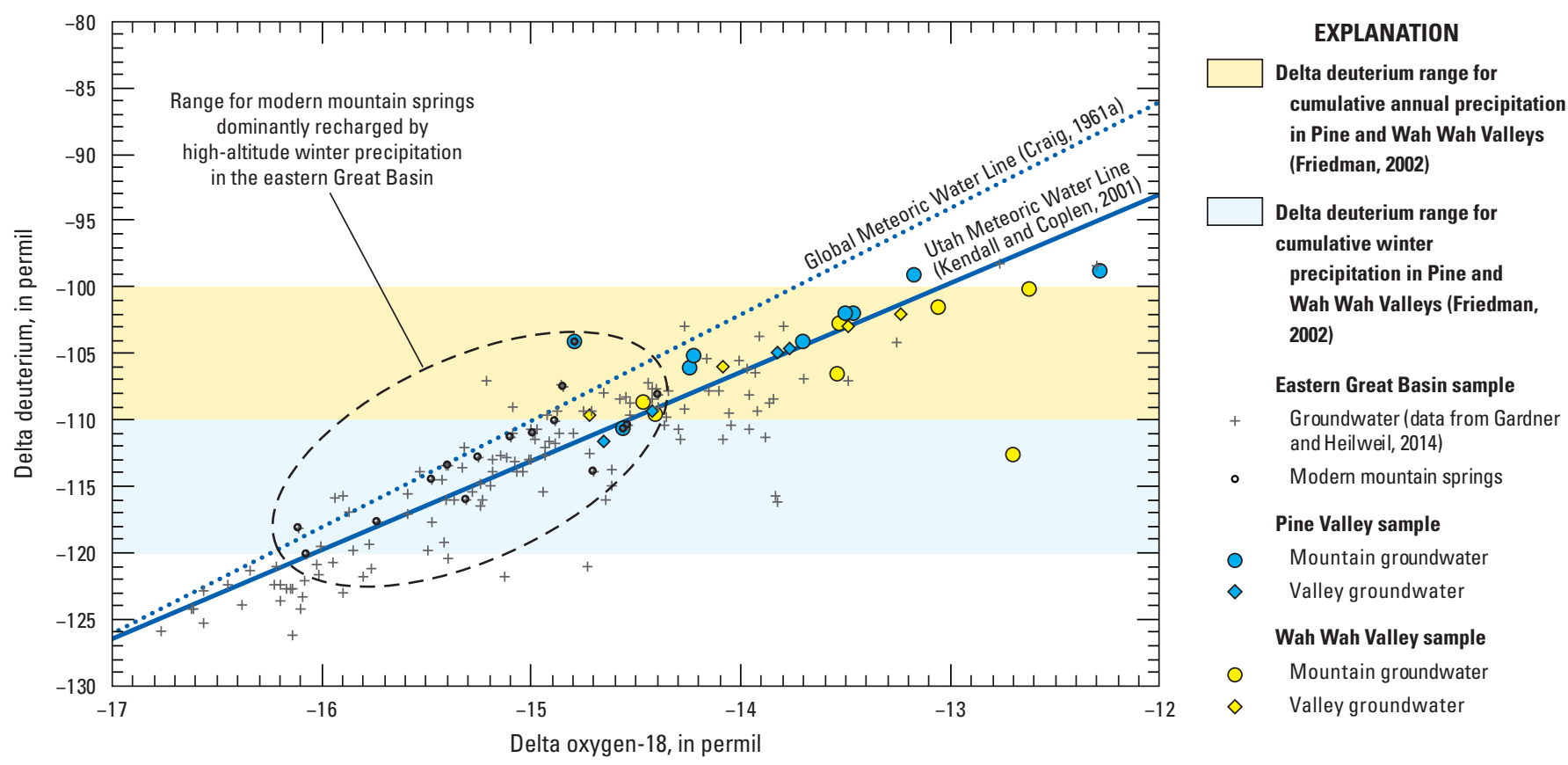

Figure 13. Stable-isotope values for selected samples from wells and springs in Pine and Wah Wah Valleys compared to stableisotope values from seven neighboring basins and ranges of modern cumulative winter and annual precipitation for Pine and Wah Wah Valleys, Utah. 
Groundwater temperatures measured near the water table from 20 valley wells in Pine and Wah Wah Valleys ranged from 14.5 to 24.9 with average of $18.9{ }^{\circ} \mathrm{C}$ (table 9). These valley water-table temperatures average 8.1 to $9.4{ }^{\circ} \mathrm{C}$ warmer than mean annual air temperatures for Pine and Wah Wah Valleys ( 9.5 and $10.8{ }^{\circ} \mathrm{C}$, respectively). Eight mountain springs and one mountain well selected to represent mountain water-table temperatures in Pine and Wah Wah Valleys ranged from 9.3 to $16.7^{\circ} \mathrm{C}$ with an average of $11.6^{\circ} \mathrm{C}$. With the mountain and valley water-table temperature ranges overlapping by $2.2^{\circ} \mathrm{C}$, the contrast between mountain and valley water-table temperatures is not as clear in Pine and Wah Wah Valleys as in other basins in the region.

Dissolved noble-gas concentrations and NGTs are presented in table 10. Average noble-gas temperatures computed for 18 sites ranged from 7.5 to $16.6^{\circ} \mathrm{C}$ and were cooler than measured water temperatures at all but 2 of the sample sites (sample IDs 5 and 7). Noble-gas recharge temperatures typically are cooler than measured water temperatures given that recharge areas are higher in altitude (and generally cooler at the water table) than the corresponding sample locations. Average noble-gas recharge temperature was greater than measured water temperatures at sites 5 and 7 by 0.8 and $1.0^{\circ} \mathrm{C}$, respectively. These are both springs where water is in contact with the air before it can be sampled, likely resulting in gases re-equilibrating with atmosphere and leading to the warmer than expected NGTs. The range of possible NGT values calculated for each site is shown on figure 14 in which the left and right points for each sample represent $\mathrm{NGT}_{\min }$ and $\mathrm{NGT}_{\max }$, respectively.

Except for Wah Wah Springs (sites 1 and 2), which are noted as being classified as "thermal" or "warm" by Stephens (1974), most mountain waters have cooler NGTs than most valley waters. There is an apparent distinction where $\mathrm{NGT}_{\text {avg }}$ for eight of nine mountain waters are cooler, and $\mathrm{NGT}_{\text {avg }}$ for six of seven valley waters are warmer than about $12.5^{\circ} \mathrm{C}$ (fig. 14). Only one sample collected from a valley well in Pine Valley (site 12) had a cool $\mathrm{NGT}_{\text {avg }}\left(11.3^{\circ} \mathrm{C}\right)$ that fell in the range of the majority of $\mathrm{NGT}_{\text {avg }}$ values for samples collected from mountain wells and springs. The cool NGT of this single valley sample indicates that mountain recharge does contribute to a fraction of valley groundwater at this site. One sample collected from a well in the hills southeast of Wah Wah Valley (site 16) had a warm $\mathrm{NGT}_{\text {avg }}\left(14.0^{\circ} \mathrm{C}\right)$ that falls in the range of $\mathrm{NGT}_{\text {avg }}$ values for samples collected from deep valley wells. Although surprisingly warm for a mountain water table, this $\mathrm{NGT}_{\text {avg }}$ was cooler than the measured temperature of $15.1^{\circ} \mathrm{C}$ at this site. The sample provides an example of warmer than expected, mountain water-table temperatures, which are likely related to elevated and variable ground temperatures near the Indian Peak Caldera Complex (Henrikson and Chapman, 2002; Blackett R.E., 2004). 
[NAD 83, North American Datum of 1983; mm/dd/yyyy, month/day/year; hhmm, hour minute; —, no information; ${ }^{\circ} \mathrm{C}$, degrees Celsius]

\begin{tabular}{|c|c|c|c|c|c|c|c|}
\hline Site name & Site number & Site type & $\begin{array}{l}\text { Latitude (decimal } \\
\text { degrees, NAD 83) }\end{array}$ & $\begin{array}{l}\text { Longitude (decimal } \\
\text { degrees, NAD 83) }\end{array}$ & $\begin{array}{l}\text { Water level date } \\
\text { (mm/dd/yyyy) }\end{array}$ & $\begin{array}{l}\text { Water level time } \\
\text { (hhmm) }\end{array}$ & $\begin{array}{c}\text { Water level } \\
\text { (feet below land surface) }\end{array}$ \\
\hline \multicolumn{8}{|c|}{ Valley } \\
\hline (C-23-12) 6ccd-1 & 385008113145301 & Well & 38.835512 & -113.248853 & 09/07/2012 & 1315 & 205 \\
\hline (C-24-12)15cdc-1 & 384306113112601 & Well & 38.718292 & -113.191350 & 09/07/2012 & 1138 & 83 \\
\hline (C-24-13)13aac-1 & 384351113150501 & Well & 38.730791 & -113.252186 & 09/07/2012 & 1215 & 96 \\
\hline (C-24-13)23ccd-1 & 384215113165701 & Well & 38.704124 & -113.283298 & 09/07/2012 & 1105 & 177 \\
\hline (C-24-13)34ccb-1 & 384042113181601 & Well & 38.678167 & -113.305222 & 09/07/2012 & 1035 & 210 \\
\hline (C-27-14)28ddd-1 & 382535113251101 & Well & 38.426349 & -113.420523 & 09/05/2012 & 1640 & 568 \\
\hline (C-27-14)28ddd-2 & 382539113250601 & Well & 38.427461 & -113.419134 & 09/05/2012 & 1645 & 562 \\
\hline (C-28-14) 3bcd-1 & 382423113243601 & Well & 38.406500 & -113.414083 & 09/04/2012 & - & 682 \\
\hline (C-28-14)10cbd-1 & 382311113244901 & Well & 38.388806 & -113.415500 & 09/04/2012 & - & 781 \\
\hline (C-28-14)11abb-1 & 382350113231901 & Well & 38.397184 & -113.389411 & 09/04/2012 & 1720 & 663 \\
\hline (C-28-14)26bbd-1 & 382105113234801 & Well & 38.351333 & -113.396556 & 09/04/2012 & - & 747 \\
\hline (C-26-14)25aad-1 & 383131113214301 & Well & 38.525237 & -113.362744 & 09/07/2012 & 0924 & 233 \\
\hline (C-25-16)18bdd-1 & 383825113410801 & Well & 38.640361 & -113.685667 & 09/06/2012 & - & 300 \\
\hline (C-25-17)33dab-1 & 383538113450801 & Well & 38.593845 & -113.753032 & 07/01/1933 & - & 466 \\
\hline (C-26-17) 3cda-1 & 383402113440601 & Well & 38.572861 & -113.742000 & 09/06/2012 & 1810 & 433 \\
\hline (C-26-17) 3cdd-1 & 383357113440601 & Well & 38.571639 & -113.741972 & 09/06/2012 & 1740 & 436 \\
\hline (C-28-17) 1cca-1dbb & 382402113421101 & Well & 38.400667 & -113.702944 & 09/06/2012 & - & 620 \\
\hline (C-28-17)11cca-1 & 382259113433701 & Well & 38.383015 & -113.727751 & 09/06/2012 & 1218 & 365 \\
\hline (C-28-17)12dcc-1 & 382256113420501 & Well & 38.382194 & -113.701500 & 09/06/2012 & - & 609 \\
\hline (C-28-17)22dda-1 & 382113113435401 & Well & 38.353571 & -113.732473 & 09/06/2012 & 1250 & 378 \\
\hline \multicolumn{8}{|c|}{ Mountain } \\
\hline (C-29-16) 2dcd-S1 & 381835113361701 & Spring & 38.309684 & -113.605526 & - & - & - \\
\hline (C-28-15)10abb-S1 & 382344113305901 & Spring & 38.395639 & -113.517194 & - & - & - \\
\hline (C-29-15) 2dad-S1 & 381848113292701 & Spring & 38.313130 & -113.491750 & - & - & - \\
\hline (C-28-16)35bac-S1 & 382016113364001 & Spring & 38.337444 & -113.611944 & - & - & - \\
\hline (C-30-17)19ddc-S1 & 381045113470701 & Spring & 38.179167 & -113.785167 & - & - & - \\
\hline (C-27-18)35ccb-1 & 382445113501401 & ${ }^{2}$ Spring & 38.412611 & -113.837139 & - & - & - \\
\hline (C-27-18)27dba-1 & 382550113504001 & Spring & 38.430639 & -113.844444 & - & - & - \\
\hline (C-26-19) 3abc-S1 & 383452113572301 & Spring & 38.581160 & -113.957250 & - & - & - \\
\hline (C-30-17)15cab-1 & 381152113442801 & Well & 38.197833 & -113.741167 & $11 / 22 / 1995$ & - & - \\
\hline
\end{tabular}


Table 9. Water temperatures from wells and springs selected to represent the water table in the valley and temperatures from Pine and Wah Wah Valleys, Utah.-Continued

[NAD 83, North American Datum of 1983; mm/dd/yyyy, month/day/year; hhmm, hour minute; —, no information; ${ }^{\circ} \mathrm{C}$, degrees Celsius]

\begin{tabular}{|c|c|c|c|c|c|c|c|}
\hline Site name & Site number & $\begin{array}{l}\text { Well depth (feet below } \\
\text { land surface) }\end{array}$ & $\begin{array}{l}\text { Top of open interval } \\
\text { (feet below } \\
\text { land surface) }\end{array}$ & $\begin{array}{l}\text { Bottom of open } \\
\text { interval (feet below } \\
\text { land surface) }\end{array}$ & $\begin{array}{c}\text { Water table } \\
\text { temperature date } \\
\text { (mm/dd/yyyy) }\end{array}$ & $\begin{array}{c}\text { 'Water table } \\
\text { temperature }\left({ }^{\circ} \mathrm{C}\right)\end{array}$ & Hydrographic area \\
\hline \multicolumn{8}{|c|}{ Valley } \\
\hline$(\mathrm{C}-23-12) 6 \mathrm{ccd}-1$ & 385008113145301 & 560 & - & - & $09 / 07 / 2012$ & 18.1 & Sevier Desert \\
\hline$(\mathrm{C}-24-12) 15 \mathrm{cdc}-1$ & 384306113112601 & 532 & - & - & 09/07/2012 & 16.6 & Sevier Desert \\
\hline (C-24-13)13aac-1 & 384351113150501 & 145 & - & - & 09/07/2012 & 17.6 & Sevier Desert \\
\hline$(\mathrm{C}-24-13) 23 \mathrm{ccd}-1$ & 384215113165701 & 201 & 178 & 201 & 09/07/2012 & 14.5 & Sevier Desert \\
\hline$(\mathrm{C}-24-13) 34 \mathrm{ccb}-1$ & 384042113181601 & 294 & 236 & 294 & 09/07/2012 & 16.1 & Wah Wah Valley \\
\hline (C-27-14)28ddd-1 & 382535113251101 & 1,399 & - & - & $09 / 05 / 2012$ & 20.8 & Wah Wah Valley \\
\hline (C-27-14)28ddd-2 & 382539113250601 & 987 & - & - & $09 / 05 / 2012$ & 20.7 & Wah Wah Valley \\
\hline (C-28-14) 3bcd-1 & 382423113243601 & 1,480 & 700 & 1,480 & 09/04/2012 & 24.9 & Wah Wah Valley \\
\hline (C-28-14)10cbd-1 & 382311113244901 & 970 & 800 & 970 & 09/04/2012 & 22.8 & Wah Wah Valley \\
\hline (C-28-14)11abb-1 & 382350113231901 & 1,475 & 680 & 1,475 & 09/04/2012 & 24.8 & Wah Wah Valley \\
\hline (C-28-14)26bbd-1 & 382105113234801 & 1,104 & 715 & 1,104 & 09/04/2012 & 20.8 & Wah Wah Valley \\
\hline (C-26-14)25aad-1 & 383131113214301 & 1,135 & 888 & 1,114 & 09/07/2012 & 16.2 & Wah Wah Valley \\
\hline (C-25-16)18bdd-1 & 383825113410801 & 340 & - & - & $06 / 15 / 2011$ & 16.7 & Pine Valley \\
\hline (C-25-17)33dab-1 & 383538113450801 & 628 & - & 628 & $12 / 03 / 2012$ & 16.6 & Pine Valley \\
\hline (C-26-17) 3cda-1 & 383402113440601 & 882 & 640 & 861 & 09/06/2012 & 18.1 & Pine Valley \\
\hline (C-26-17) 3cdd-1 & 383357113440601 & 870 & 560 & 850 & 09/06/2012 & 18.7 & Pine Valley \\
\hline (C-28-17) 1cca-1dbb & 382402113421101 & 1,460 & 500 & 1,460 & 09/06/2012 & 19.0 & Pine Valley \\
\hline (C-28-17)11cca-1 & 382259113433701 & 970 & 270 & 970 & 09/06/2012 & 18.6 & Pine Valley \\
\hline (C-28-17)12dcc-1 & 382256113420501 & 1,120 & 400 & 1,120 & 09/06/2012 & 17.8 & Pine Valley \\
\hline (C-28-17)22dda-1 & 382113113435401 & 2,006 & 500 & 2,006 & 09/06/2012 & 18.2 & Pine Valley \\
\hline \multicolumn{8}{|c|}{ Mountain } \\
\hline (C-29-16) 2dcd-S1 & 381835113361701 & - & - & - & $10 / 11 / 1972$ & 11.0 & Wah Wah Valley \\
\hline (C-28-15)10abb-S1 & 382344113305901 & - & - & - & $12 / 04 / 2012$ & 13.7 & Wah Wah Valley \\
\hline (C-29-15) 2dad-S1 & 381848113292701 & - & - & - & $06 / 28 / 2011$ & 12.3 & Wah Wah Valley \\
\hline (C-28-16)35bac-S1 & 382016113364001 & - & - & - & $12 / 05 / 2012$ & 9.3 & Pine Valley \\
\hline (C-30-17)19ddc-S1 & 381045113470701 & - & - & - & $12 / 06 / 2012$ & 11.4 & Pine Valley \\
\hline (C-27-18)35ccb-1 & 382445113501401 & 2.5 & 1.5 & 2.5 & $12 / 05 / 2012$ & 11.6 & Pine Valley \\
\hline (C-27-18)27dba-1 & 382550113504001 & - & - & - & $12 / 05 / 2012$ & 9.3 & Pine Valley \\
\hline (C-26-19) 3abc-S1 & 383452113572301 & - & - & - & $06 / 16 / 2011$ & 9.5 & Pine Valley \\
\hline (C-30-17)15cab-1 & 381152113442801 & 385 & 365 & 385 & $08 / 29 / 2013$ & 16.7 & Pine Valley \\
\hline
\end{tabular}

${ }^{1}$ Water-table temperatures in wells were measured just below the free surface of the water using a Solnist 1,000-foot electric water-level tape equiped with a temperature sensor except in wells

(C-25-17)33dab-1 and (C-30-17)15cab-1, where the temperature is of pumped water assumed to approximate the water table. Springs selected to represent water-table temperature had sufficient flow to

accurately represent ground temperature at their location. Wah Wah Springs were excluded due to being classified as "warm" or "thermal springs" by Stephens (1974).

${ }^{2}$ Spring temperature measured from the shallow well completed in sediments at the discharge location. 
Table 10. Dissolved-gas concentrations and related noble-gas temperature data for groundwater sampled from Pine and Wah Wah Valleys, Utah.

[Sample identification (ID): See figure 10 for locations and table 5 for additional information. Dissolved-gas sample collection method: CT, copper tube; DS, diffusion sampler. Abbreviations: USGS, U.S. Geological Survey; mmHg, millimeters of mercury; ${ }^{\circ} \mathrm{C}$, degrees Celsius; ${ }^{20} \mathrm{Ne}$, Neon-20; ccSTP/g, cubic centimeters at standard temperature and pressure per gram of water; ${ }^{40} \mathrm{Ar}$, Argon- $40 ;{ }^{84} \mathrm{Kr}$, Krypton- $84 ;{ }^{129} \mathrm{Xe}$, Xenon- $129 ;-$, no information; $\mathrm{H}_{\min }$, minimum recharge altitude; $\mathrm{NGT}_{\max }$, dimensionless ratio of the total volume of trapped (moist) air at the pressure and temperature of the free atmosphere to the volume of water; A, average noble-gas recharge temperature; F, fractionation factor for partial dissolution of trapped air bubbles; $\sum_{x}^{2}$, sum of error-weighted misfit for each of the noble gases; $\mathrm{H}_{\text {avg }}$, average recharge altitude; $\mathrm{NGT}_{\text {avg }} ; \mathrm{H}_{\max }$, maximum recharge altitude; $\mathrm{NGT}_{\text {min }}$, minimum noble-gas recharge temperature]

\begin{tabular}{|c|c|c|c|c|c|c|c|c|c|c|c|}
\hline \multirow{2}{*}{$\begin{array}{c}\text { Sample } \\
\text { ID }\end{array}$} & \multirow[t]{2}{*}{ USGS site number } & \multirow{2}{*}{$\begin{array}{l}\text { Sample } \\
\text { method }\end{array}$} & \multirow{2}{*}{$\begin{array}{l}\text { Dissolved- } \\
\text { gas pressure } \\
(\mathrm{mmHg})\end{array}$} & \multirow{2}{*}{\multicolumn{2}{|c|}{$\begin{array}{c}\text { Water } \\
\text { temperature } \\
\left({ }^{\circ} \mathrm{C}\right)\end{array}$}} & \multicolumn{6}{|c|}{$\begin{array}{l}\text { Dissolved noble-gas concentrations } \\
\text { (ccSTP/g) }\end{array}$} \\
\hline & & & & & & ${ }^{20} \mathrm{Ne}$ & \multicolumn{2}{|c|}{${ }^{40} \mathrm{Ar}$} & ${ }^{84} \mathrm{Kr}$ & \multicolumn{2}{|r|}{${ }^{129} \mathrm{Xe}$} \\
\hline 1 & 382901113295701 & DS & 608 & \multicolumn{2}{|c|}{19.0} & $1.56 \mathrm{E}-07$ & \multicolumn{2}{|c|}{$2.93 \mathrm{E}-04$} & $3.76 \mathrm{E}-08$ & \multicolumn{2}{|r|}{$2.33 \mathrm{E}-09$} \\
\hline 2 & 382856113293301 & DS & 594 & \multicolumn{2}{|c|}{17.5} & $1.54 \mathrm{E}-07$ & \multicolumn{2}{|c|}{$2.95 \mathrm{E}-04$} & $3.82 \mathrm{E}-08$ & \multicolumn{2}{|r|}{$2.39 \mathrm{E}-09$} \\
\hline 3 & 382344113305901 & DS & 636 & \multicolumn{2}{|c|}{13.7} & $1.70 \mathrm{E}-07$ & \multicolumn{2}{|c|}{$3.17 \mathrm{E}-04$} & $4.21 \mathrm{E}-08$ & \multicolumn{2}{|r|}{$2.76 \mathrm{E}-09$} \\
\hline 4 & 382016113364001 & DS & 577 & \multicolumn{2}{|c|}{9.3} & $1.44 \mathrm{E}-07$ & \multicolumn{2}{|c|}{$3.19 \mathrm{E}-04$} & $4.09 \mathrm{E}-08$ & \multicolumn{2}{|r|}{ 2.93E-09 } \\
\hline 5 & 381045113470701 & DS & 582 & 11.4 & & $1.61 \mathrm{E}-07$ & & -04 & $3.86 \mathrm{E}-08$ & & $2.49 \mathrm{E}-09$ \\
\hline 6 & 382445113501401 & DS & 539 & 11.6 & & $1.49 \mathrm{E}-07$ & & -04 & $3.95 \mathrm{E}-08$ & & $2.72 \mathrm{E}-09$ \\
\hline 7 & 382550113504001 & DS & 542 & 9.3 & & $1.42 \mathrm{E}-07$ & & -04 & $3.99 \mathrm{E}-08$ & & $2.67 \mathrm{E}-09$ \\
\hline 8 & 383131113214301 & CT & 537 & 19.9 & & $3.19 \mathrm{E}-08$ & & -04 & $1.34 \mathrm{E}-07$ & & $2.51 \mathrm{E}-09$ \\
\hline 9 & 383538113450801 & CT & 699 & 16.6 & & $1.47 \mathrm{E}-07$ & & -04 & $3.34 \mathrm{E}-08$ & & $2.34 \mathrm{E}-09$ \\
\hline 10 & 381344113512301 & CT & 716 & 12.5 & & $3.93 \mathrm{E}-07$ & & -04 & $5.59 \mathrm{E}-08$ & & 3.23E-09 \\
\hline 11 & 383402113440601 & CT & 813 & 19.5 & & $3.66 \mathrm{E}-07$ & & -04 & $4.34 \mathrm{E}-08$ & & $2.72 \mathrm{E}-09$ \\
\hline 12 & 382259113433701 & CT & - & 20.0 & & $5.10 \mathrm{E}-07$ & & -04 & $5.25 \mathrm{E}-08$ & & $3.11 \mathrm{E}-09$ \\
\hline 13 & 381152113442801 & CT & - & 16.7 & & $1.82 \mathrm{E}-07$ & & -04 & $4.34 \mathrm{E}-08$ & & $2.74 \mathrm{E}-09$ \\
\hline${ }^{1} 14$ & 382539113250601 & CT & 683 & 21.9 & & $1.83 \mathrm{E}-07$ & & -04 & $9.74 \mathrm{E}-09$ & & 2.22E-09 \\
\hline 15 & 382101113170801 & CT & 683 & 14.6 & & $1.55 \mathrm{E}-07$ & & -04 & $4.03 \mathrm{E}-08$ & & $2.56 \mathrm{E}-09$ \\
\hline 16 & 381957113163701 & CT & 726 & 15.1 & & $1.79 \mathrm{E}-07$ & & -04 & $3.89 \mathrm{E}-08$ & & $2.59 \mathrm{E}-09$ \\
\hline 17 & 382423113243601 & CT & 705 & 23.7 & & $1.63 \mathrm{E}-07$ & & -04 & $3.92 \mathrm{E}-08$ & & $2.44 \mathrm{E}-09$ \\
\hline 18 & 383825113410801 & $\mathrm{CT}$ & - & 16.7 & & $1.56 \mathrm{E}-07$ & & -04 & $3.62 \mathrm{E}-08$ & & $2.50 \mathrm{E}-09$ \\
\hline 19 & 384042113181601 & CT & - & 16.2 & & $1.55 \mathrm{E}-07$ & & -04 & $3.99 \mathrm{E}-08$ & & $2.56 \mathrm{E}-09$ \\
\hline & & & & & & Modeled & chara & ameters & & & \\
\hline $\begin{array}{c}\text { Sample } \\
\text { ID }\end{array}$ & USGS site number & $\begin{array}{l}\text { Sample } \\
\text { method }\end{array}$ & $\begin{array}{c}H_{\min } \\
\text { (feet) }\end{array}$ & $\begin{array}{l}\mathrm{NGT}_{\max } \\
\left({ }^{\circ} \mathrm{C}\right)\end{array}$ & A & $\mathbf{F}$ & $\Sigma_{x}^{2}$ & $\underset{\text { (feet) }}{\mathrm{H}_{\text {avg }}}$ & $\begin{array}{l}\mathrm{NGT}_{\text {avg }} \\
\left({ }^{\circ} \mathrm{C}\right)^{-}\end{array}$ & $\begin{array}{c}H_{\max } \\
\text { (feet) }\end{array}$ & $\begin{array}{l}\mathbf{N G T}_{\text {min }} \\
\left({ }^{\circ} \mathrm{C}\right)^{-}\end{array}$ \\
\hline 1 & 382901113295701 & DS & 5,666 & 17.3 & 0.0009 & 0.88 & 0.13 & 6,833 & 16.6 & 8,000 & 15.9 \\
\hline 2 & 382856113293301 & DS & 5,531 & 16.2 & 0.0007 & 0.90 & 0.14 & 6,766 & 15.5 & 8,000 & 14.8 \\
\hline 3 & 382344113305901 & DS & 5,850 & 10.6 & 0.0010 & 0.00 & 0.12 & 6,925 & 9.5 & 8,000 & 8.4 \\
\hline 4 & 382016113364001 & DS & 7,211 & 7.8 & 0.0001 & 0.99 & 1.24 & 7,606 & 7.5 & 8,000 & 7.2 \\
\hline 5 & 381045113470701 & DS & 6,900 & 13.1 & 0.0014 & 0.00 & 2.07 & 7,650 & 12.2 & 8,400 & 11.3 \\
\hline 6 & 382445113501401 & DS & 6,276 & 11.1 & 0.0003 & 0.95 & 0.56 & 6,938 & 10.5 & 7,600 & 9.9 \\
\hline 7 & 382550113504001 & DS & 6,335 & 10.7 & 0.0000 & 0.96 & 0.24 & 6,968 & 10.3 & 7,600 & 9.9 \\
\hline 8 & 383131113214301 & CT & 4,760 & 14.8 & 0.0000 & 1.18 & 6.90 & 6,380 & 14.2 & 8,000 & 13.4 \\
\hline 9 & 383538113450801 & CT & 5,276 & 17.6 & 0.0003 & 0.00 & 1.79 & 6,638 & 15.9 & 8,000 & 14.2 \\
\hline 10 & 381344113512301 & $\mathrm{CT}$ & 7,805 & 8.7 & 0.0300 & 0.17 & 0.22 & 8,103 & 8.4 & 8,400 & 8.2 \\
\hline 11 & 383402113440601 & CT & 5,249 & 16.8 & 0.0120 & 0.00 & 4.66 & 6,825 & 14.9 & 8,400 & 13.1 \\
\hline 12 & 382259113433701 & CT & 5,682 & 12.8 & 0.0220 & 0.00 & 0.53 & 7,041 & 11.3 & 8,400 & 9.8 \\
\hline 13 & 381152113442801 & CT & 6,548 & 12.2 & 0.0480 & 0.73 & 0.01 & 7,474 & 11.3 & 8,400 & 10.5 \\
\hline${ }^{1} 14$ & 382539113250601 & CT & 5,085 & - & - & - & - & - & - & - & - \\
\hline 15 & 382101113170801 & CT & 6,161 & 12.1 & 0.0031 & 0.70 & 0.38 & 6,381 & 11.8 & 6,600 & 11.6 \\
\hline 16 & 381957113163701 & CT & 6,240 & 14.2 & 0.0290 & 0.71 & 0.81 & 6,420 & 14.0 & 6,600 & 13.8 \\
\hline 17 & 382423113243601 & CT & 5,210 & 15.0 & 0.0010 & 0.00 & 0.91 & 6,605 & 13.4 & 8,000 & 11.7 \\
\hline 18 & 383825113410801 & CT & 5,089 & 15.7 & 0.0010 & 0.00 & 1.47 & 6,744 & 13.7 & 8,400 & 11.7 \\
\hline 19 & 384042113181601 & $\mathrm{CT}$ & 4,655 & 14.8 & 0.0000 & 0.00 & 2.53 & 6,528 & 12.8 & 8,400 & 10.8 \\
\hline
\end{tabular}

${ }^{1}$ Noble gas concentrations yielded no acceptable NGT model, which was likely due to erroneously low ${ }^{84} \mathrm{Kr}$ and ${ }^{129} \mathrm{Xe}$ concentrations. 


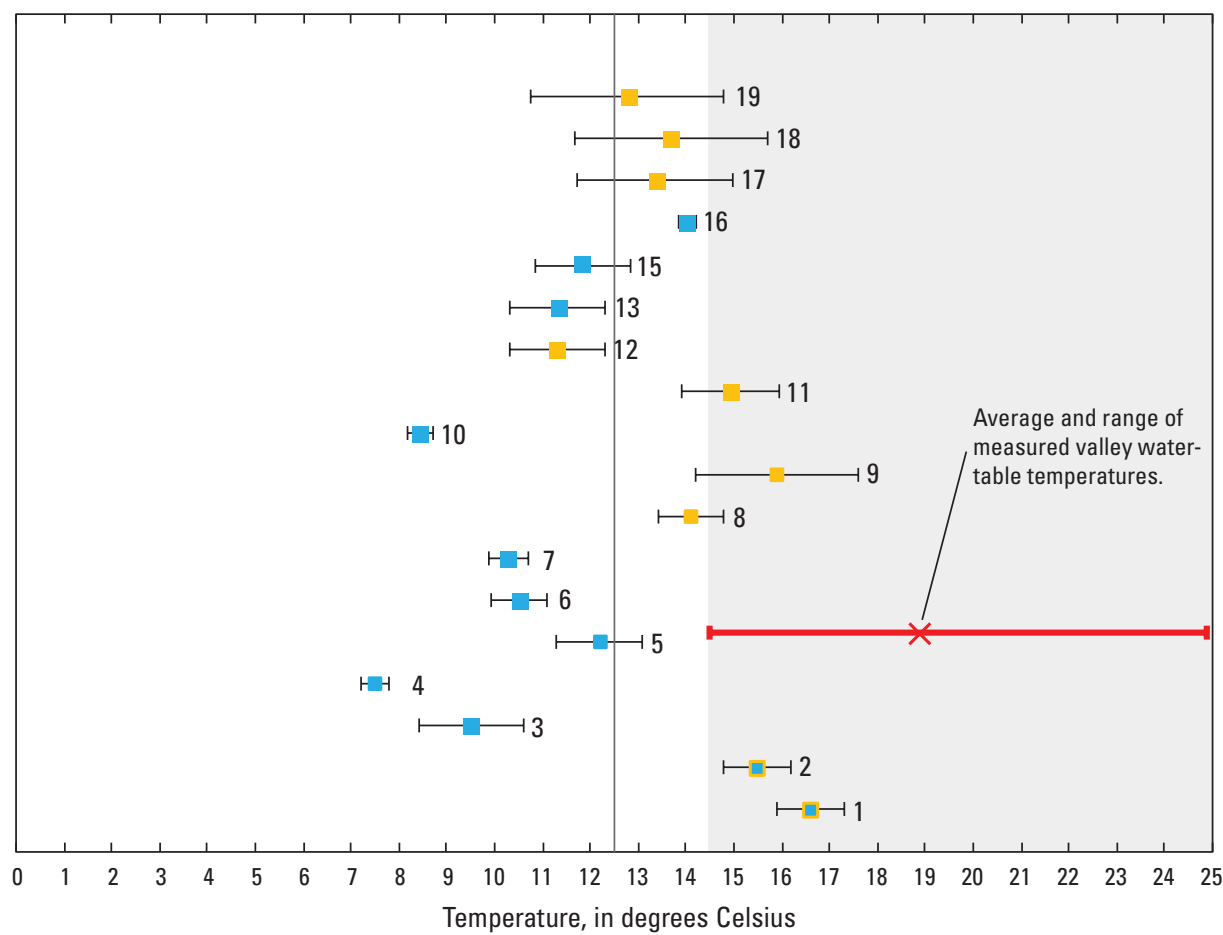

EXPLANATION

_- Thermal and warm mountain

_

_- Valley wells

$\mathrm{NGT}_{\min } \quad \mathrm{NGT}_{\text {avg }} \quad \mathrm{NGT}_{\max }$

$\mathrm{NGT}_{\text {min }}$-minimum noble-gas recharge temperature $\mathrm{NGT}_{\text {avg }}$-average noble-gas recharge temperature $\mathrm{NGT}_{\text {max }}$-maximum noble-gas recharge temperature Number to the right is the site identifier

Figure 14. Computed noble-gas recharge temperatures compared to measured valley water-table temperatures for groundwater sites sampled in Pine and Wah Wah Valleys, Utah.

\section{Discussion}

In many ways, the Pine and Wah Wah Valleys are like many watersheds in the eastern Great Basin. Both are internally drained, surface-water basins bounded by steep normal faults. The valleys contain thick basin-fill deposits that form the principal source of available groundwater and are surrounded by bedrock mountain highlands. Precipitation rates are generally too low to provide in-place groundwater recharge at low altitudes. Instead, most recharge originates as precipitation falling on the mountains surrounding the valleys.

In many comparable nearby basins, mountain precipitation exceeds consumptive use (evaporation and transpiration by plants) in the mountains so that a fraction of the precipitation is available to recharge the aquifer. This is a function of the amount and timing of the precipitation. Most precipitation in these basins occurs in the mountains during the winter. Whether or not it is stored as snowpack and released as snowmelt in the spring, more of it is available for groundwater recharge because ET rates are much lower during the cooler months, seasonally reducing consumptiveuse rates. In these areas, recharge enters the aquifer system as direct infiltration where mountains are composed of permeable bedrock at the surface. If the permeable bedrock extends to the mountain front, this infiltration can recharge the basin-fill aquifer directly through the subsurface. In mountain areas with less-permeable bedrock, precipitation and snowmelt form runoff that gathers in stream channels and infiltrates permeable basin-fill deposits near the mountain front to recharge basinfill aquifers.

Despite some similarities, Pine and Wah Wah Valleys also differ from typical regional watersheds in ways that have important implications regarding groundwater resource evaluation and management. A few of these basin characteristics that have notable effects on the groundwater hydrology are (1) igneous rocks associated with the Indian Peak Caldera Complex resulting in extensive perched (or semi-perched) mountain aquifers that are disconnected from the adjacent basin-fill aquifers, (2) a smaller fraction of the precipitation in these valleys occurs during winter months leading to a larger fraction of annual precipitation being consumed by evapotranspiration during the summer and leaving less available for groundwater recharge, and (3) the majority of groundwater discharge from Pine and Wah Wah Valleys occurs through the subsurface and is therefore not observable or measurable, precluding the use of discharge measurements to constrain independent estimates of groundwater recharge. 


\section{Hydrologic Characteristics of the Basins}

Approximately the southern two-thirds of the mountains surrounding Pine and Wah Wah Valleys are composed of extrusive and intrusive igneous rocks, quartzite, and metasedimentary rocks (VU and NCCU in fig. 4). These rocks typically have low primary permeability and only localized, near-surface secondary permeability. Stephens (1976) reported that these conditions created perched (or semi-perched ${ }^{1}$ ) mountain aquifers where significant discharge occurs to mountain springs, noting "Examination of spring locations, topography, and geology on maps and in the field indicates that many of the springs that discharge from the extrusive igneous rocks on the eastern flank of the Needle Mountains probably are perched. They issue either from a surficial weathered zone or from permeable interbeds within the volcanic rocks."

Stephens $(1974,1976)$ also mentions the shallow watertable conditions in stream-channel alluvium along the major washes and streams draining the Needle and Wah Wah Ranges and states "These shallow water table areas probably do not represent a regional water table. Instead, they appear to be perched zones resulting from the accumulation of ground water in permeable unconsolidated deposits underlain by less permeable, unsaturated consolidated rocks." Early evidence for extensive perched groundwater in the mountains was based on field inspection and the observation that the 80 or more springs in the Pine Valley drainage basin all discharge at altitudes above $6,200 \mathrm{ft}$, which is above the mountainbedrock, basin-fill transition zone. Although the number of springs is fewer and the altitude of the mountain-bedrock, basin-fill transition is lower $(5,400 \mathrm{ft})$, the same pattern is apparent in Wah Wah Valley. Furthermore, comparing groundwater altitudes from wells and springs in the mountains to groundwater levels measured in valley wells anywhere in Pine or Wah Wah Valleys shows that a hydraulic gradient across the mountain-bedrock, basin-fill transition zone would be unusually steep for any well-connected flow system (fig. 4), reinforcing that perched mountain groundwater is widespread. The Gould State No. 3 oil and gas exploration well, about six miles outside of the Pine Valley drainage basin at the northern end of the Mountain Home Range (fig. 4), provides a direct observation supporting the concept of perched mountain groundwater. During drilling of this well, fresh water was encountered in carbonate rocks with a static water level at

\footnotetext{
${ }^{1}$ Meinzer (1923, p. 40) defines perched groundwater as that which is separated from an underlying body of groundwater by unsaturated rock stating that "Perched water belongs to a different zone of saturation from that occupied by the underlying ground water." Perched groundwater is sometimes confused with semi-perched groundwater, which Meinzer (1923, p. 41) defines as groundwater that "has greater pressure head than an underlying body of ground water, from which it is, however, not separated by any unsaturated rock."
}

750 -ft below the land surface of $6,362 \mathrm{ft}$, confirming that the regional water table in bedrock at this location is about $5,612 \mathrm{ft}$ and well beneath the altitude of "shallow water-table areas" in the Mountain Home and Indian Peak Ranges to the south.

A significant implication of extensive perched mountain groundwater is a degree of hydraulic disconnection between groundwater that recharged in the mountains and groundwater in the adjacent basin-fill aquifers. In addition to the geologic and hydrologic evidence discussed above, groundwater geochemistry also indicates discontinuous flow between mountain recharge areas and basin-fill aquifers. Groundwater samples from valley wells in Pine Valley clearly have lower dissolved-solids concentrations than almost all the groundwater sampled from wells and springs in the surrounding mountains (fig. 10; table 6). A similar pattern is seen when comparing mountain versus valley groundwater samples in Wah Wah Valley, although with slightly more overlap in dissolved-solids concentration. Groundwater should acquire solutes over time as it moves downgradient along a flow path. In areas where flow paths are continuous between mountain and valley groundwater, dissolved-solids concentrations in water from valley wells should be higher than upgradient mountain waters, especially given the long travel time indicated by the groundwater ages (fig. 12).

In a similar way, NGTs also indicate a hydraulic discontinuity between mountain and valley groundwaters. Because NGTs are derived from dissolved noble-gas concentrations representing the temperature of a water sample at its point of recharge, and because the noble gases are generally preserved in the saturated zone, NGTs should remain constant along continuous groundwater flow paths. This pattern, however is not generally observed in Pine or Wah Wah Valleys. Excluding the thermal waters discharging from Wah Wah Springs, the NGT avg for all but one of the valley groundwater samples are notably warmer than the $\mathrm{NGT}_{\text {avg }}$ for all but one of the mountain groundwater samples (fig. 14). The contrast is not wholly conclusive on its own; NGTs for several of the samples overlap when the complete range $\left(\mathrm{NGT}_{\min }\right.$ to $\mathrm{NGT}_{\max }$ ) is considered (fig. 14). However, this represents a conservative range of uncertainty given that samples are unlikely to have recharged at the highest or lowest altitudes used in their calculation. Consequently, this pattern further supports the premise that much of valley recharge is not derived from direct infiltration of precipitation in the mountains. The cool NGT of one sample from Pine Valley (site 12) indicates, however, that permeable pathways do exist allowing mountain recharge to reach the valley aquifers in some places. This is expected given that the lowpermeability volcanic rocks responsible for perched mountain groundwater are not continuous across the whole of the surrounding mountains. 
Stable-isotope values for 7 out of the 23 meteoric waters sampled (excluding the highly evaporated sample from site 21) were isotopically enriched (heavier) compared to modern mountain springs dominantly recharged by winter precipitation in nearby parts of the eastern Great Basin (fig. 13). This indicates that much of the groundwater in the study basins originated as either low-altitude or warm-season precipitation. However, because many of the enriched waters were samples collected from mountain springs, all that can be concluded is that warm season rather than winter precipitation is the source of much of the groundwater in the mountain and valley aquifers.

Of the samples that did have isotopic values representing high-altitude winter precipitation, four of the samples $(1,2,22$, and 24) are mountain springs that are directly downgradient from mountain catchments between 8,600 and $9,300 \mathrm{ft}$ in altitude (fig. 10). One of them (sample 19) is Pleistocene in age and represents water recharged during a cooler and wetter climate (fig. 12). The remaining two (sample IDs 9 and 11) are basin-fill waters that are downgradient of an exposed block of permeable carbonate (the Needles) surrounded by low-permeability igneous and metasedimentary rocks on the eastern flank of the Needle Mountains in western Pine Valley. This isolated carbonate block is one of the likely locations where mountain infiltration can move through permeable rock at depth and become recharge to the basin-fill deposits beneath the valley floor.

Stable-isotope data provide useful information about the seasonality of precipitation occurring in Pine and Wah Wah Valleys. Twenty-one of 24 samples had $\delta^{2} \mathrm{H}$ values indicative of cumulative annual rather than cumulative winter precipitation (fig. 13). This makes sense considering that about half of all precipitation at the Desert Experimental Range Station and Wah Wah Ranch occurs during May-September (fig. 3). Furthermore, Stephens (1974) noted that winter precipitation (mostly snowfall) during December-March accounts for less than one-fourth of the annual precipitation in the valleys and probably not more than one-third of the annual precipitation in the mountains.

The timing of precipitation has important implications for valley recharge. More than 80 percent of recharge previously estimated using a modified Maxey-Eakin method (Hood and Waddell, 1968) is from precipitation occurring above the altitude of the mountain-bedrock, basin-fill transition in both valleys where normal annual precipitation exceeds 10-12 in/yr (Stephens, 1974, 1976). However, much of the area where recharge occurs is below the mountain-bedrock, basin-fill transition where runoff from the higher parts of the drainage basin infiltrates the relatively permeable sand and gravel deposits in and along the stream channels. If most precipitation occurs during winter months when evapotranspiration rates are lowest, much less of it is consumptively used in the mountains, and more is available to recharge the basin-fill aquifers at the mountain front. If, however, most precipitation occurs during the warm months, natural consumptive use in the mountains could leave little available for recharge by the time water arrives at the permeable sand and gravel deposits below the mountainbedrock, basin-fill transition.

Another unique characteristic of the Pine and Wah Wah Valley drainage basins is their lack of natural discharge at the lowest altitudes of the valley floors. Most comparable valleys in the eastern Great Basin have extensive areas of lowland discharge where groundwater levels are near the land surface and the bulk of the basin's groundwater discharge occurs through springs and by phreatophyte evapotranspiration. Groundwater levels in Pine and Wah Wah Valleys, however, are hundreds of feet below land surface, even beneath dry playas at the lowest valley altitudes. A consequence of the deep groundwater levels is that all discharge from the basinfill aquifers in both valleys must occur through the subsurface where it is not observable and cannot be measured.

\section{Groundwater Budget}

As of 2014 there were approximately 54,000 acre feet (acre-ft) of outstanding, unapproved water-right applications for groundwater from Pine and Wah Wah Valleys. Recent proposals to develop groundwater resources in Pine and Wah Wah Valleys are focused on extraction of groundwater from their extensive basin-fill aquifers. The long-standing estimate of annual groundwater recharge to these valleys combined is 28,000 acre-ft/year (Stephens, 1974, 1976). However, it has never been formally recognized that the groundwater budgets presented by Stephens clearly indicate that substantially less than the full 28,000 acre-ft recharges the basin-fill aquifers. Although various other groundwater budget estimates have been reported in the recent decade (Masbruch, 2011a; Brooks and others, 2014; Masbruch and others, 2014, tables A3-2,14), they have come out of largescale or multi-basin studies not focused on Pine and Wah Wah Valleys. This study collected new hydrologic data with the specific intention of re-evaluating the conceptual model of the groundwater flow and providing information to update groundwater budgets using the GBCAAS v. 3.0 numerical model (Brooks, 2017a, b). 
The groundwater budgets reported by Stephens (1974, 1976) are summarized in table 11 to clarify what fraction of recharge contributes to the basin-fill aquifer in each valley. Total annual recharge from precipitation to Pine and Wah Wah Valleys is estimated to be 21,000 and 7,000 acre-ft/yr, respectively. It is important to note that 3,000 acre-ft/yr of this recharge is reported to leave the Pine Valley drainage basin (discharge from Pine Valley) and move into the Wah Wah Valley drainage basin (recharge to Wah Wah Valley) through permeable carbonate rocks along the drainage divide in the Wah Wah Mountains. Recognizing that this amount not be double counted, the total annual recharge to both basins remains 28,000 acre-ft. An additional 7,100 acre-ft of discharge from Pine Valley is reported to occur in perched zones in the surrounding mountains and is clearly inferred to be lost to consumptive uses, mostly evapotranspiration. The difference between the recharge from precipitation $(21,000$ acre-ft) and the sum of mountain discharge (7,100 acre-ft) in the Pine Valley drainage, plus the subsurface discharge to Wah Wah Valley through consolidated rocks in the Wah Wah Mountains (3,000 acre- $\mathrm{ft}$ ) is assumed to leave the basin-fill aquifer as subsurface discharge (11,000 acre-ft, rounded) to the north. The same reasoning is used in reporting the Wah Wah Valley groundwater budget where the sum of mountain discharge components (150 and 1,400 acre-ft) is subtracted from the sum of recharge from precipitation (7,000 acre-ft) and the component of Pine Valley recharge that moves into Wah Wah through consolidated rocks in the Wah Wah Mountains (3,000 acre-ft) to arrive at the amount leaving the basin-fill aquifer as subsurface discharge $(8,500$ acre- $\mathrm{ft}$, rounded) to the north. These budget estimates are based on the premise of significant perched or semi-perched conditions in the mountains surrounding both valleys, which is substantiated by geochemical and physical evidence presented in this study. Assuming steady-state conditions, recharge to the basin-fill aquifers is equal to the subsurface discharge from the basin-fill aquifers in each valley (11,000 and 8,500 acre-ft for Pine and Wah Wah Valleys, respectively).

Steady-state groundwater budgets for Pine and Wah Wah Valleys from simulations by the GBCAAS v. 3.0 model (Brooks, 2017a, b) are compared to the average annual groundwater budgets of only the basin-fill aquifers from Stephens $(1974,1976)$ in table 12 . The basin-fill only portions of these budgets are equal to the "unconsumed recharge that moves northward through the basin-fill aquifer and leaves as subsurface outflow" shown in the final row of the Pine and Wah Wah Valley sections of table 11. Moreover, this comparison is made because only the basin-fill portions of the budgets presented by Stephens $(1974,1976)$ are physically available for withdrawal. Wah Wah Springs is the only spring or spring complex where groundwater discharge is simulated by the numerical model. Discharge of groundwater was not simulated by the model for other mountain springs or by phreatophytic ET in areas of shallow mountain groundwater and the calibrated model did not include recharge to supply them. Therefore, recharge simulated by the model is equal to the amount of water that remains in the groundwater system and either discharges at Wah Wah Springs or moves through the basin-fill aquifers before leaving as subsurface discharge toward the north. To compare recharge estimates for the basin-fill only, the Wah Wah Springs discharge (750 acre-ft) that is simulated by the GBCAAS v. 3.0 model was subtracted from the total recharge simulated for Wah Wah Valley (3,200 acre-ft; Brooks, 2017a, table 8) to yield the modelestimated recharge to the basin-fill (2,500 acre-ft, rounded).

The reason that Wah Wah Springs is uniquely represented in the GBCAAS v. 3.0 model is given by Brooks and others (2014): "Springs with flow rates less than $300 \mathrm{gal} / \mathrm{min}$ were not simulated unless they were near other springs. These smaller springs could represent local conditions that are not simulated in this regional model, such as perched conditions or irrigation return flow. Discharge from springs that are less than $300 \mathrm{gal} / \mathrm{min}$ accounts for less than 2 percent of the discharge for the [GBCAAS] study area..." Wah Wah Springs is the only spring discharging more than $300 \mathrm{gal} / \mathrm{min}$ in all of Pine and Wah Wah Valleys. It is actually a collection of discrete springs, seeps, and an area of $\mathrm{ET}_{\mathrm{g}}$ that is controlled by local geologic structure and thought to capture recharge from an area that extends across the drainage divide into Pine Valley as described in detail by Stephens (1974). The discharge from Wah Wah Springs measured during this study is approximately $1,000 \mathrm{gal} / \mathrm{min}\left(2.3-2.2 \mathrm{ft}^{3} / \mathrm{s}\right.$ or $\left.1,600 \mathrm{acre}-\mathrm{ft} / \mathrm{yr}\right)$, which is two times the discharge reported by Stephens (1974) and two times that discharge simulated using the GBCAAS v. 3.0 model. This discharge was measured through a rectangular weir in a collection box and is thought to represent nearly all of the spring flow from the complex. Because the water from Wah Wah Springs principally is used for irrigation on the valley floor, it is reasonable to assume that 50 percent of measured discharge is consumptively used and that the remaining water recharges the basin-fill aquifer. And because the discharge of spring flow from Wah Wah Springs reported by Stephens (1974; 800 acre-ft) and that simulated using the GBCAAS v. 3.0 model (750 acre-ft), both are approximately 50 percent of what was measured during 2013-16; it is assumed for this budget analysis that those estimates represent consumptive discharge. 
Table 11. Summary of conceptual steady-state groundwater budgets reported by Stephens (1974, 1976) for Pine and Wah Wah Valleys, Utah.

[All values rounded to two significant figures, in acre-feet per year (acre-ft/yr) unless otherwise noted.]

\begin{tabular}{|c|c|}
\hline Value & Description \\
\hline \multicolumn{2}{|r|}{ Pine Valley } \\
\hline \multicolumn{2}{|c|}{ Groundwater recharge } \\
\hline \multicolumn{2}{|c|}{ Groundwater discharge } \\
\hline 27,100 & Sum of consumed groundwater discharge occurring in the mountains. \\
\hline${ }^{4} 11,000$ & Unconsumed recharge that moves northward through the basin-fill aquifer and leaves as subsurface outflow. \\
\hline
\end{tabular}

\begin{tabular}{|c|c|}
\hline \multicolumn{2}{|r|}{ Wah Wah Valley } \\
\hline \multicolumn{2}{|c|}{ Groundwater recharge } \\
\hline${ }^{17}, 000$ & Recharge from precipitation. \\
\hline \multicolumn{2}{|c|}{ Groundwater discharge } \\
\hline${ }^{4} 8,500$ & Unconsumed recharge that moves northward through the basin-fill aquifer and leaves as subsurface outflow. \\
\hline
\end{tabular}

${ }^{1}$ Modified Maxey-Eakin estimate of groundwater recharge from precipitation in the drainage basin in Stephens (1974, p. 11; 1976, p. 12)

${ }^{2}$ Sum of groundwater discharge occurring in the mountains in the Pine Valley drainage basin that is consumed by evapotranspiration without reaching the basin-fill aquifer is summarized in Stephens (1976, p. 17).

${ }^{3}$ Estimate of recharge occurring in the Wah Wah Mountains within the Pine Valley drainage basin that flows under the topographic divide into the Wah Wah Valley drainage is described in Stephens (1974, p. 12; 1976, p. 12). This same 3,000 acre-ft is reported as discharge from Pine Valley and recharge to Wah Wah Valley.

${ }^{4}$ Estimate of subsurface discharge out of the basin-fill aquifer calculated as the difference between total recharge and groundwater discharge consumed in the mountains surrounding the basin-fill aquifer is described in Stephens (1974, p. 30; 1976, p. 17).

${ }^{5}$ Sum of small components of discharge occurring in the mountains within the Wah Wah Valley drainage basin that is consumed by evapotranspiration without reaching the basin-fill aquifer, excluding spring or groundwater evapotranspiration discahrge associated with Wah Wah Springs is summarized in Stephens (1974, p. 13, 20, and 26).

${ }^{6}$ Combined estimates of Wah Wah Springs discahrge and groundwater discharged by evapotranspiration in the area surrounding Wah Wah Springs (Stephens, 1974, p. 21).

Table 12. Conceptual and simulated (using the GBCAAS v. 3.0 groundwater model) steady-state groundwater budgets for the basin-fill aquifers of Pine and Wah Wah Valleys, Utah.

[All values rounded to two significant figures, in acre-feet per year unless otherwise noted.]

\begin{tabular}{lccc}
\hline \multicolumn{1}{c}{ Source } & & Annual groundwater recharge/discharge \\
\hline Conceptual (Stephens, 1976) basin-fill only & Pine Valley & Wah Wah Valley & Combined \\
Simulated (Brooks, 2017) basin-fill only & ${ }^{1} 11,000$ & ${ }^{1} 8,500$ & 20,000 \\
\hline
\end{tabular}

${ }^{1}$ Unconsumed recharge that moves northward through the basin-fill aquifer and leaves as subsurface outflow is reported in table 11.

${ }^{2}$ With the exception of Wah Wah Springs, Brooks (2017) does not simulate recharge to supply spring discharge and groundwater evapotranspiration occurring in the mountains surrounding Pine and Wah Wah Valleys. The model-simulated discharge from Wah Wah Springs is assumed to represent a consumptive loss and is subtracted from the total recharge to Wah Wah Valley. 
The simulated groundwater budget for the Pine Valley basin-fill aquifer appears essentially unchanged from the reconnaissance study of Stephens (1976). The simulated groundwater budget for Wah Wah Valley basin-fill aquifer is significantly reduced. These reductions in recharge resulted in (1) lower simulated water levels on the west side of Sevier Lake that more closely matched measured water levels and (2) accurate simulation of the revised conceptual model having no regional groundwater discharging as ET directly from the Sevier Lake playa. There is one nuance associated with the GBCAAS v. 3.0 model groundwater budgets that complicates a basin-by-basin comparison; the model-simulated budgets represent recharge occurring within the basin boundary and do not address the fate of the 3,000 acre-ft of Pine Valley recharge that moves into the Wah Wah Valley drainage basin. This complication is irrelevant when comparing the combined simulated recharge for the two basins. At 14,000 acre-ft (rounded), the combined annual steady-state recharge to the basin-fill aquifers simulated using the GBCAAS v. 3.0 model is about 30 percent less than the 20,000 acre-ft (rounded) reported in Stephens $(1974,1976)$.

The conceptual and simulated estimates are uncertain because recharge is notoriously difficult to quantify (Bredehoeft, 2007), verification of independent recharge estimates using methods like Maxey-Eakin (Maxey and Eakin, 1949) and the Basin Characterization Model (Flint and Flint, 2007a) relies on accurate discharge measurements. If, for example, coefficients determining the fraction of precipitation that becomes recharge in a Maxey-Eakin estimate were determined for a basin dominated by winter precipitation, they could overestimate recharge in basins where most precipitation occurs at other times of the year. Measuring discharge to verify a Maxey-Eakin recharge estimate is not possible in either Pine or Wah Wah Valleys where most basin-wide discharge occurs through the subsurface and is not measurable. And, for reasons given by Brooks (2017a, p. 50), the GBCAAS v. 3.0 model would require significant revision to accurately simulate shallow mountain aquifers and their interaction with the adjacent basin-fill aquifers. Regardless of the uncertainties, the basin-fill aquifers in Pine and Wah Wah Valley are recharged by an amount that very likely lies between the estimates presented in table 12 .

Because all groundwater in the basin-fill aquifers leaves as subsurface outflow, Pine and Wah Wah Valleys are clearly part of a larger, multiple-basin groundwater flow system. Although the recharge estimates presented could help water managers define a conceptual limit on groundwater withdrawal, it should be noted that pumping in the Pine and Wah Wah basins will have to capture discharge from neighboring basins because there is no groundwater discharging from the valleys in either of these basins. With the springs and ET areas in the mountains present in perched aquifers, the principal effect of increased groundwater withdrawal in the Pine and Wah Wah Valleys basin-fill aquifers would be a reduction in the quantity of subsurface outflow. This, in turn would result in reduced discharge in areas outside of the basin, most likely in Tule Valley and the Sevier Desert.

\section{Summary}

A groundwater resources assessment was conducted in Pine and Wah Wah Valleys to provide a better understanding of groundwater presence, sources, and movement.

Groundwater in Pine and Wah Wah Valleys is being targeted for large-scale extraction and export to provide municipal supply to growing populations in Iron County, Utah. Concern about potential declining groundwater levels and spring flows resulting from proposed groundwater withdrawals necessitates an improved understanding of the Pine and Wah Wah Valleys groundwater system. This study evaluated hydrologic conditions including groundwater levels, recharge to the groundwater system, discharge from springs, and evapotranspiration (ET). Geochemistry and environmental groundwater tracers were used to determine sources of water to groundwater discharge areas, evaluate groundwater flow paths, and assess interbasin flow between adjacent valleys. Previous studies estimated that an average of 28,000 acrefeet per year (acre-ft/yr) of recharge occurs as infiltration of precipitation in the two basins (Stephens, 1974, 1976). Groundwater discharge that occurs in mountain hydrologic systems was estimated to average $8,500 \mathrm{acre}-\mathrm{ft} / \mathrm{yr}$ and assumed to be consumed before subsequently recharging the valley basin-fill aquifers. Subsurface groundwater discharge from basin-fill aquifers in Pine and Wah Wah Valleys that moves northward to adjacent regional basins was estimated to average 19,500 acre-ft/yr.

Aquifer properties for the basin-fill aquifers in Pine and Wah Wah Valleys were determined from 10 single-well pump tests where a value for specific capacity was calculated. The transmissivity calculated for the basin-fill aquifer in Pine and Wah Wah Valleys mostly ranged from about 400 to 9,000 square feet per day $\left(\mathrm{ft}^{2} / \mathrm{d}\right.$; table 1$)$. One well, CICWCD \#25, in the far southern portion of Pine Valley, yielded a transmissivity of about $20-30 \mathrm{ft}^{2} / \mathrm{d}$. Another well, CICWCD \#11, in south-central Pine Valley, yielded a transmissivity range of $94,000-120,000 \mathrm{ft}^{2} / \mathrm{d}$. 
A water-level map for the basin-fill aquifers in Pine and Wah Wah Valleys was constructed using water-level measurements taken at wells and springs in the surrounding mountain regions totaling 64 sites (fig. 4; table A-1). Pine and Wah Wah Valleys are closed surface-water basins, but groundwater levels indicate that groundwater moves northward out of both valleys toward adjacent basins. Waterlevel and spring discharge fluctuations in Pine and Wah Wah Valleys are presented for seven wells and two springs. In all seven wells, water levels are generally stable for the period of record at each site with maximum observed fluctuations of less than 5 feet (ft). Sites with shorter periods of record (less than 10 years) show short-term increases and decreases, which could be delayed responses to climatic variability. In both springs, discharge remained stable from 2013 to 2016.

New estimates of groundwater ET $\left(\mathrm{ET}_{\mathrm{g}}\right)$ in Tule Valley and the Sevier Lake basin were made by (1) mapping the groundwater discharge areas in each basin; (2) evaluating 2005-11 summer multispectral satellite images against the Basin and Range carbonate-rock aquifer system, studying ET measurements to select scenes broadly representative of average conditions in the study area, and partitioning the groundwater discharge areas into ET units using the selected satellite images and field reconnaissance; and (3) scaling ET to the ET units using ET rate estimates from comparable study areas in the Great Basin. The resulting updated estimates of average annual $\mathrm{ET}_{\mathrm{g}}$ in the Tule Valley and Sevier Lake groundwater discharge areas are 35,000 and 10,500 acre-ft/yr, respectively, with a likely uncertainty of plus or minus 35 percent. Updated $\mathrm{ET}_{\mathrm{g}}$ estimates for these two areas were made to better constrain Pine and Wah Wah Valley groundwater budgets using the Great Basin carbonate and alluvial aquifer system Version 3.0 groundwater flow model (Brooks, 2017a,b).

Groundwater samples from 13 sites in Pine Valley and 11 sites in Wah Wah Valley were analyzed for major ions and nutrients to characterize geochemistry and water quality. Groundwater samples also were analyzed for the stable isotopes of oxygen, hydrogen, and carbon; the radioactive isotopes of carbon and hydrogen; and dissolved noble gases including helium-3, helium-4, neon, argon, krypton, and xenon. Groundwater sampling sites included 12 wells and 12 springs.

Carbon-14 and tritium/helium groundwater age dating indicate that groundwater in the basin-fill aquifers is typically thousands to tens of thousands of years older than groundwater in the shallow mountain aquifers. Dissolvedsolids concentrations are lower and noble-gas temperatures are warmer in valley wells compared to almost all groundwater sampled from wells and springs in the surrounding mountains. These results, combined with the steep hydraulic gradients observed between mountain and valley locations, indicate a widespread hydraulic discontinuity between mountain and valley aquifers throughout much of the study area, and that much of the valley recharge is not derived from direct infiltration of precipitation in the mountains. However, noblegas recharge temperatures from one and stable-isotope values from two Holocene-aged groundwater samples indicate that areas exist where mountain infiltration can move through permeable rock at depth and recharge adjacent basin-fill valley aquifers. Furthermore, the geology within the mountains and between the mountains and valleys is complex, and areas of hydraulic connections between valley aquifers and mountain springs cannot be ruled out completely. Groundwater levels are deep throughout the basin-fill aquifers of Pine and Wah Wah Valleys and neither contains areas of measurable groundwater discharge that can be used to verify groundwater budget estimates. As such, the steady-state average annual recharge to and discharge from the combined valleys is best bracketed between the simulated estimate of Brooks $(2017, a, b)$ and the reconnaissance estimates of Stephens $(1974,1976)$ at 14,000-20,000 acre-ft.

\section{References Cited}

Aeschbach-Hertig, W., Peeters, F., Beyerle, U., and Kipfer, R., 2000, Paleotemperature reconstruction from noble gases in ground water taking into account equilibration with entrapped air: Nature, v. 405, no. 6790, p. 1040-1044, https://doi.org/10.1038/35016542.

Allander, K.K., Smith, J.L., and Johnson, M.J., 2009, Evapotranspiration from the lower Walker River Basin, west-central Nevada, water years 2005-07: U.S. Geological Survey Scientific Investigations Report 2009-5079, 63 p., https://doi.org/10.3133/sir20095079.

Berger, D.L, Mayers, C.J., Garcia, C.A., Buto, S.G., and Huntington, J.M., 2016, Budgets and chemical characterization of groundwater for the Diamond Valley flow system, central Nevada, 2011-12: U.S. Geological Survey Scientific Investigations Report 2016-5055, 83 p., https://doi.org/10.3133/sir20165055.

Best, M.G., Christiansen, E.H., Deino, A.L., Gromme, S., Hart, G.L., and Tingey, D.G., 2013, The 36-18 Ma Indian Peak-Caliente ignimbrite field and calderas, southeastern Great Basin, USA-Multicyclic supereruptions: Geosphere, v. 9, no. 4, p. 864-950, https://doi.org/10.1130/GES00902.1.

Blackett, R.E., 2004, Geothermal gradient data for Utah: Utah Geological Survey Open-File Report 431, 49 p., http://files.geology.utah.gov/emp/geothermal/pdf/utah_ temp_grad.pdf.

Bredehoeft, J.D., 2007, It is the discharge:

Groundwater, v. 45, no. 5, p. 523, https://doi.org/10.1111/j.1745-6584.2007.00305.x. 
Brooks, L.E., Masbruch, M.D., Sweetkind, D.S., and Buto, S.G., 2014, Steady-state numerical groundwater flow model of the Great Basin carbonate and alluvial aquifer system study area: U.S. Geological Survey Scientific Investigations Report 2014-5213, 124 p., 2 pl., https://doi.org/10.3133/sir20145213.

Brooks, L.E., 2017a, Groundwater model of the Great Basin carbonate and alluvial aquifer system version 3.0-Incorporating revisions in southwestern Utah and east central Nevada: U.S. Geological Survey Scientific Investigations Report 2017-5072, 77 p., 2 appendixes, https://doi.org/10.3133/sir20175072.

Brooks, L.E., 2017b, MODLFOW-LGR data sets for the Great Basin carbonate and alluvial aquifer system model version 3.0-Revisions in southwestern Utah and east central Nevada: U.S. Geological Survey Data Release, https://doi.org/10.5066/F76T0JW1.

Cederberg, J.R., Sweetkind, D.S., Buto, S.G., and Masbruch, M.D., 2011, Three-dimensional hydrogeologic framework, appendix 1 of Heilweil, V.M., and Brooks, L.E., eds., Conceptual model of the Great Basin carbonate and alluvial aquifer system: U.S. Geological Survey Scientific Investigations Report 2010-5193, p. 127-141, https://doi.org/10.3133/sir20105193.

Clarke, W.B., Jenkins, W.J., and Top, Z., 1976, Determination of tritium by mass spectrometric measurements of ${ }^{3} \mathrm{He}$ : The International Journal of Applied Radiation and Isotopes, v. 27, no. 9, p. 515-522, https://doi.org/10.1016/0020-708X(76)90082-X.

Cooper, H.H., Jr., and Jacob, C.E., 1946, A generalized graphical method for evaluating formation constants and summarizing wellfield history: American Geophysical Union, v. 27, no. 4, p. 526-534, https://doi.org/10.1029/TR027i004p00526.

Coplen, T.B., 1994, Reporting of stable hydrogen, carbon, and oxygen isotopic abundances: Pure and Applied Chemistry, v. 66, no. 2, p. 273-276, https://doi.org/10.1351/pac199466020273.

Craig, H., 1961a, Isotopic variations in meteoric waters: Science, v. 133 , no. 3465 , p. 1702-1703, https://doi.org/10.1126/science.133.3465.1702.

Craig, H., 1961b, Standard for reporting concentrations of deuterium and oxygen-18 in natural waters: Science, v. 133, no. 3467, p. 1833-1834, https://doi.org/10.1126/science.133.3467.1833.
Daly, C., Halbleib, M., Smith, J.I., Gibson, W.P., Doggett, M.K., Taylor, G.H., Curtis, J., and Pasteris, P.A., 2008, Physiographically sensitive mapping of climatological temperature and precipitation across the conterminous United States: International Journal of Climatology, v. 28, no. 15, p. 2031-2064, https://doi.org/10.1002/joc.1688.

de Vries, H., 1958, Variation in concentration of radiocarbon with time and location on earth: Proceedings of the Koninklijke Nederlandse Akademie van Wetenschappen, v. B61, no. 2, p. 1-9.

Flint, A.L., and Flint, L.E., 2007a, Application of the basin characterization model to estimate in-place recharge and runoff potential in the Basin and Range carbonaterock aquifer system, White Pine County, Nevada, and adjacent areas in Nevada and Utah: U.S. Geological Survey Scientific Investigations Report 2007-5099, 20 p., https://doi.org/10.3133/sir20075099.

Fontes, J.C., and Garnier, J.M., 1979, Determination of initial ${ }^{14} \mathrm{C}$ activity of the total dissolved carbon-A review of existing models and a new approach: Water Resources Research, v. 15, no. 2, p. 399-413, https://doi.org/10.1029/WR015i002p00399.

Freeze, R.A., and Cherry, J.A., 1979, Groundwater: Englewood Cliffs, N.J., Prentice-Hall, 604 p.

Friedman, I., Smith, G.I., Johnson, C.A., and Moscati, R.J., 2002, Stable isotope compositions of waters in the Great Basin, United States 2-Modern precipitation: Journal of Geophysical Research D-Atmospheres, v. 107, no. 19, https://doi.org/10.1029/2001JD000566.

Garcia, C.A., Huntington, J.M., Buto, S.G., Moreo, M.T., Smith, J.L., and Andraski, B.J., 2015, Groundwater discharge by evapotranspiration, Dixie Valley, westcentral Nevada, March 2009-September 2011: U.S. Geological Survey Professional Paper 1805, 90 p., https://doi.org/10.3133/pp1805.

Gardner, P.M., and Heilweil, V.M., 2014, A multipletracer approach to understanding regional groundwater flow in the Snake Valley area of the eastern Great Basin, USA: Applied Geochemistry, v. 45, p. 33-49, https://doi.org/10.1016/j.apgeochem.2014.02.010.

Gardner, P., and Solomon, D.K., 2009, An advanced passive diffusion sampler for the determination of dissolved gas concentrations: Water Resources Research, v. 45, no. 6, https://doi.org/10.1029/2008WR007399. 
Gardner, P.M., Masbruch, M.D., Plume, R.W., and Buto, S.G., 2011, Regional potentiometric-surface map of the Great Basin carbonate and alluvial aquifer system in Snake Valley and surrounding areas, Juab, Millard, and Beaver Counties, Utah, and White Pine and Lincoln Counties, Nevada:

U.S. Geological Survey Scientific Investigations Map 3193, 2 sheets, https://doi.org/10.3133/sim3193.

Gates, J.S., and Kruer, S.A., 1981, Hydrologic reconnaissance of the southern Great Salt Lake Desert and summary of the hydrology of west-central Utah: U.S. Geological Survey Technical Publication 71, 55 p., https://pubs.er.usgs.gov/publication/70043705.

Glenn, E.P., Huete, A.R., Nagler, P.L., and Nelson, S.G., 2008, Relationship between remotely-sensed vegetation indices, canopy attributes and plant physiological processesWhat vegetation indices can and cannot tell us about the landscape: Sensors (Basel), v. 8, no. 4, p. 2136-2160, https://doi.org/10.3390/s8042136.

Harrill, J.R., and Prudic, D.E., 1998, Aquifer systems in the Great Basin region of Nevada, Utah, and adjacent statesSummary report: U.S. Geological Survey Professional Paper 1409-A, 66 p., https://doi.org/10.3133/pp1409A.

Hart, R., Nelson, S.T., and Eggett, D., 2010, Uncertainty in ${ }^{14} \mathrm{C}$ model ages of saturated zone waters-The influence of soil gas in terranes dominated by $\mathrm{C}_{3}$ plants: Amsterdam, The Netherlands, Journal of Hydrology, v. 392, no. 1-2, p. 83-95, https://doi.org/10.1016/j.jhydrol.2010.08.001.

Henrikson, A., and Chapman, D.S., 2002, Terrestrial heat flow in Utah: Salt Lake City, Utah, University of Utah, Department of Geology and Geophysics Open-File Report 431, 47 p., https://ugspub.nr.utah.gov/publications/ open_file_reports/ofr-431/ofr-431_terrestrial-heat-flowutah.pdf.

Hood, J.W., and Waddell, K.M., 1968, Hydrologic reconnaissance of Skull Valley, Tooele County, Utah: State of Utah, Department of Natural Resources Technical Publication No. 18, https://waterrights.utah.gov/docSys/ v920/w920/w920008g.pdf.

Huete, A., Justice, C., and van Leeuwen, W., 1999, MODIS vegetation index (MOD 13), Algorithm theoretical basis document, Version 3: National Aeronautics and Space Administration, $20 \mathrm{p}$., https://modis.gsfc.nasa.gov/data/atbd/atbd_mod13.pdf.

Huntington, J.L., and Allen, R.G., 2010, Evapotranspiration and net irrigation water requirements for Nevada: Nevada Department of Conservation and Natural Resources Division of Water Resources, 288 p.
Jackson, T.R., Halford, K.J., Gardner, P.M., and Garcia, A., 2018, Evaluating micrometeorological estimates of groundwater discharge from Great Basin desert playas: Groundwater, v. 56, no. 6, p. 909-920, https://doi.org/10.1111/gwat.12647.

Kendall, C., and Coplen, T.B., 2001, Distribution of oxygen-18 and deuterium in river waters across the United States: Hydrological Processes, v. 15, no. 7, p. 1363-1393, https://doi.org/10.1002/hyp.217.

Kennedy, C.D., and Genereux, D.P., 2007, ${ }^{14}$ C groundwater age and the importance of chemical fluxes across aquifer boundaries in confined Cretaceous aquifers of North Carolina, USA: Radiocarbon, v. 49, no. 3, p. 1181-1203, https://doi.org/10.1017/S0033822200043101.

Kipfer, R., Aeschbach-Hertig, W., Peeters, F., and Stute, M., 2002, Noble gases in lakes and ground waters, in Porcelli, D., Ballentine, C.J., and Wieler, R., eds., Noble gases in geochemistry and cosmochemistry: Chantilly, Va., Mineralogical Society of America, Reviews in Mineralogy and Geochemistry, v. 47, p. 615-700, https://doi.org/10.1515/9781501509056-016.

Laczniak, R.J., DeMeo, G.A., Reiner, S.R., Smith, J.L., and Nylund, W.E., 1999, Estimates of ground-water discharge as determined from measurements of evapotranspiration, Ash Meadows area, Nye County, Nevada: U.S. Geological Survey Water-Resources Investigations Report 99-4079, 70 p., https://doi.org/10.2172/750059.

Laczniak, R.J., Smith, J.L., Elliott, P.E., DeMeo, G.A., and Chatigny, M.A., 2001, Ground-water discharge determined from estimates of evapotranspiration, Death Valley regional flow system, Nevada and California: U.S. Geological Survey Water-Resources Investigations Report 01-4195, 51 p., https://doi.org/10.2172/790204.

Laczniak, R.J., Flint, A.L., Moreo, M.T., Knochenmus, L.A., Lundmark, K.W., Pohll, G., Carroll, R.W.H., Smith, J.L., Welborn, T.L., Heilweil, V.M., Pavelko, M.T., Hershey, R.L., Thomas, J.M., Earman, S., and Lyles, B.F., 2008, Groundwater budgets in Welch, A.H., Bright, D.J., and Knochenmus, L.A., eds., Water resources of the Basin and Range Carbonate-Rock Aquifer system, White Pine County, Nevada, and adjacent areas in Nevada and Utah: U.S. Geological Survey Scientific Investigations Report 2007-5261, p. 43-68, https://doi.org/10.3133/sir20075261.

Manning, A.H., 2009, Ground-water temperature, noble gas, and carbon isotope data from the Española Basin, New Mexico: Reston, Va., U.S. Geological Survey Scientific Investigations Report 2008-5200, 69 p., https://doi.org/10.3133/sir20085200. 
Manning, A.H., 2011, Mountain-block recharge, present and past, in the eastern Española Basin, New Mexico, USA: Hydrogeology Journal, v. 19, no. 2, p. 379-397, https://doi.org/10.1007/s10040-010-0696-8.

Manning, A.H., and Solomon, D.K., 2003, Using noble gases to investigate mountain-front recharge: Amsterdam, The Netherlands, Journal of Hydrology, v. 275, nos. 3-4, p. 194 207, https://doi.org/10.1016/S0022-1694(03)00043-X.

Masbruch, M.D., 2011, Current study groundwater recharge estimates for predevelopment conditions and ranges of previously reported estimates of groundwater recharge for each hydrographic area within the Great Basin carbonate and alluvial aquifer system study area, appendix 4 of Heilweil, V.M., and Brooks, L.E., eds., Conceptual model of the Great Basin carbonate and alluvial aquifer system: U.S. Geological Survey Scientific Investigations Report 2010-5193, p. 165-170, https://doi.org/10.3133/sir20105193.

Masbruch, M.D., Chapman, D.S., and Solomon, D.K., 2012, Air, ground, and groundwater recharge temperatures in an alpine setting, Brighton Basin, Utah: Water Resources Research, v. 48, no. 10, https://doi.org/10.1029/2012WR012100.

Masbruch, M.D., Gardner, P.M., and Brooks, L.E., 2014, Hydrology and numerical simulation of groundwater movement and heat transport in Snake Valley and surrounding areas, Juab, Millard, and Beaver Counties, Utah, and White Pine and Lincoln Counties, Nevada: U.S. Geological Survey Scientific Investigations Report 2014-5103, 108 p., 10.3133/sir20145103.

Maxey, G.B., and Eakin, T.E., 1949, Ground water in White River Valley, White Pine, Nye, and Lincoln Counties, Nevada: State of Nevada, Office of the State Engineer Water Resources Bulletin No. 8, 64 p., https://www.nrc.gov/docs/ML0331/ML033140348.pdf.

Meinzer, O.E., 1923, The occurrence of ground water in the United States, with a discussion of principles: U.S. Geological Survey Water Supply Paper 489, 321 p., https://doi.org/10.3133/wsp489.

Moreo, M.T., Laczniak, R.J., and Stannard, D.I., 2007, Evapotranspiration rate measurements of vegetation typical of ground-water discharge areas in the Basin and Range carbonate-rock aquifer system, White Pine County, Nevada and adjacent areas in Nevada and Utah, September 2005-August 2006: U.S. Geological Survey Scientific Investigations Report 2007-5078, 36 p., https://doi.org/10.3133/sir20075078.

Nichols, W.D., 2000, Regional ground-water evapotranspiration and ground-water budgets, Great Basin, Nevada: U.S. Geological Survey Professional Paper 1628, 82 p., https://doi.org/10.3133/pp1628.
Plummer, L.N., and Sprinkle, C.L., 2001, Radiocarbon dating of dissolved inorganic carbon in groundwater from confined parts of the upper Floridan aquifer, Florida, USA: Hydrogeology Journal, v. 9, no. 2, p. 127-150, https://doi.org/10.1007/s100400000121.

Qi, J., Chehbouni, A., Huete, A.R., Kerr, Y.H., and Sorooshian, S., 1994, A modified soil adjusted vegetation index: Remote Sensing of Environment, v. 48, no. 2, p. 119-126, https://doi.org/10.1016/0034-4257(94)90134-1.

Reimer, P.J., Bard, E., Bayliss, A., Beck, J.W., Blackwell, P.G., Ramsey, C.B., Buck, C.E., Cheng, H., Edwards, R.L., Friedrich, M., Grootes, P.M., Guilderson, T.P., Haflidason, H., Hajdas, I., Hatté, C., Heaton, T.J., Hoffmann, D.L., Hogg, A.G., Hughen, K.A., Kaiser, K.F., Kromer, B., Manning, S.W., Niu, M., Reimer, R.W., Richards, D.A., Scott, E.M., Southon, J.R., Staff, R.A., Turney, C.S.M., and van der Plicht, J., 2013, Intcal13 and marine 09 radiocarbon age calibration curves $0-50,000$ years cal bp: Radiocarbon, v. 55, no. 4, p. 1869-1887, https://doi.org/10.2458/azu_js_rc.55.16947.

Rouse, J.W., Haas, R.H., Schell, J.A., and Deering, D.W., 1974, Monitoring vegetation systems in the Great Plains with ERTS: Proceedings of the third Earth Resources Technology Satellite-1 Symposium, Washington, D.C., NASA Scientific and Technical Information Office, p. 309317.

Schwinning, S., and Sala, O.E., 2004, Hierarchy of responses to resource pulses in arid and semi-arid ecosystems: Oecologia, v. 141, no. 2, p. 211-220, https://doi.org/10.1007/s00442-004-1520-8.

Sheldon, A., 2002, Diffusion of radiogenic helium in shallow ground water-Implications for crustal degassing: Salt Lake City, Utah, University of Utah, Ph.D. Dissertation, 185 p.

Smith, J.L., Laczniak, R.J., Moreo, M.T., and Welborn, T.L., 2007, Mapping evapotranspiration units in the Basin and Range carbonate-rock aquifer system, White Pine County, Nevada, and adjacent areas in Nevada and Utah: U.S. Geological Survey Scientific Investigations Report 2007-5087, 20 p., https://doi.org/10.3133/sir20075087.

Solomon, D.K., 2000, ${ }^{4} \mathrm{He}$ in groundwater, in Cook, P.G., and Herczeg, A.L., eds., Environmental tracers in subsurface hydrology: Boston, Mass., Kluwer Academic Publishers, p. 425-439, https://doi.org/10.1007/978-1-4615-4557-6_14.

Stuiver, M., Reimer, P.J., and Reimer, R.W., 2005, CALIB 5.0., accessed September 6, 2018, at http://calib.org/calib/. 
Stephens, J.C., 1974, Hydrologic reconnaissance of the Wah Wah Valley drainage basin, Millard and Beaver Counties, Utah: Utah Department of Natural Resources, Division of Water Rights Technical Publication No. 47, 53 p., https://pubs.er.usgs.gov/publication/70043778.

Stephens, J.C., 1976, Hydrologic reconnaissance of the Pine Valley drainage basin, Millard, Beaver, and Iron Counties, Utah: Utah Department of the Natural Resources, Division of Water Rights Technical Publication No. 51, 38 p., https://pubs.er.usgs.gov/publication/70042823.

Stute, M., and Schlosser, P., 2000, Atmospheric noble gases in Cook, P.G., and Herczeg, A.L., eds., Environmental tracers in subsurface hydrology,: Boston, Mass., Kluwer Academic Publishers, 529 p.

U.S. Department of Agriculture, 2012, National Agriculture Imagery Program: U.S. Department of Agriculture, Farm Service Agency, Aerial Photography Field Office, datasets, https://gis.apfo.usda.gov/arcgis/rest/services.

U.S. Environmental Protection Agency, 2014, Drinking water contaminants: U.S. Environmental Protection Agency website, accessed September 2014, at https://www.epa.gov/dwstandardsregulations\#mcls.
U.S. Geological Survey, 2012, Landsat Ecosystem Disturbance Adaptive Processing System (LEDAPS) Algorithm description document, version 1.3:

U.S. Geological Survey, 20 p., accessed December 10, 2013, at https://landsat.usgs.gov/documents/ledaps_add.pdf.

U.S. Geological Survey, 2017, The National Map_-3DEP products and services: U.S. Geological Survey, The National Map, 3D Elevation Program web page, https://nationalmap.gov/3DEP/3dep_prodserv.html.

Welch, A.H., Bright, D.J., and Knochenmus, L.A., eds., 2007, Water resources of the Basin and Range carbonaterock aquifer system, White Pine County, Nevada, and adjacent areas in Nevada and Utah: U.S. Geological Survey Scientific Investigations Report 2007-5261, 96 p., https://doi.org/10.3133/sir20075261.

Wilberg, D.E., 1991, Hydrologic reconnaissance of the Sevier Lake Area, west-central Utah: State of Utah, Department of Natural Resources Technical Publication No. 96, 51 p., https://waterrights.utah.gov/docSys/v920/y920/ y9200004.pdf.

Wilde, F.D., and Radtke, D.B., 1998, Field measurements: U.S. Geological Survey Techniques of Water-Resources Investigations, book 9, chap. A6, variously paged. 


\section{Appendix A: Hydrologic Site Information}

Table A-1. Selected attributes of wells and water levels measured in wells used in constructing the water-level surface map for Pine and Wah Wah Valleys and surrounding areas, Utah.

[Horizontal coordinate information is referenced to the North American Datum of 1983 (NAD 83). Abbreviations: USGS, U.S. Geological Survey; mm/dd/ yyyy, month/day/year; -, no information; <, less than]

\begin{tabular}{|c|c|c|c|c|c|c|c|c|}
\hline USGS site number & Site name & $\begin{array}{l}\text { Latitude } \\
\text { (decimal } \\
\text { degrees) }\end{array}$ & $\begin{array}{l}\text { Longitude } \\
\text { (decimal } \\
\text { degrees) }\end{array}$ & $\begin{array}{l}\text { Well } \\
\text { depth } \\
\text { (feet) }\end{array}$ & $\begin{array}{c}\text { Altitude } \\
\text { of land } \\
\text { surface } \\
\text { (feet) }\end{array}$ & $\begin{array}{c}\text { Measurement } \\
\text { date } \\
\text { (mm/dd/yyy) }\end{array}$ & $\begin{array}{c}\text { Depth to } \\
\text { water below } \\
\text { land surface } \\
\text { (feet) }\end{array}$ & $\begin{array}{c}\text { Water- } \\
\text { level } \\
\text { altitude } \\
\text { (feet) }\end{array}$ \\
\hline 382402113421101 & $(\mathrm{C}-28-17) 1 \mathrm{dbb}-1$ & 38.400667 & -113.702944 & 1,460 & 5,585 & $09 / 06 / 2012$ & 620.2 & 4,965 \\
\hline 382256113420501 & $(\mathrm{C}-28-17) 12 \mathrm{dcc}-1$ & 38.382194 & -113.701500 & 1,120 & 5,657 & 09/06/2012 & 609.2 & 5,048 \\
\hline 382259113433701 & (C-28-17)11 cca-1 & 38.383015 & -113.727751 & 970 & 5,683 & 09/06/2012 & 365.2 & 5,318 \\
\hline 382113113435401 & $(\mathrm{C}-28-17) 22 \mathrm{dda}-1$ & 38.353571 & -113.732473 & 2,006 & 5,775 & 09/06/2012 & 377.6 & 5,397 \\
\hline 381931113200201 & (C-28-13)32cdd-1 & 38.325333 & -113.333833 & 194 & 5,845 & 09/04/2012 & 26.8 & 5,818 \\
\hline 382105113234801 & (C-28-14)26bbd-1 & 38.351333 & -113.396556 & 1,104 & 5,385 & 09/04/2012 & 747.5 & 4,638 \\
\hline 382311113244901 & (C-28-14)10cbd-1 & 38.388806 & -113.415500 & 970 & 5,320 & 09/04/2012 & 781.4 & 4,539 \\
\hline 382350113231901 & (C-28-14)11abb-1 & 38.397184 & -113.389411 & 1,475 & 5,195 & 09/04/2012 & 663.0 & 4,532 \\
\hline 382423113243601 & (C-28-14) 3bcd-1 & 38.406500 & -113.414083 & 1,480 & 5,210 & 09/04/2012 & 682.0 & 4,528 \\
\hline 381037113474001 & (C-30-17)30bab-1 & 38.176306 & -113.795500 & 286 & 7,193 & 09/06/2012 & 17.1 & 7,176 \\
\hline 382539113250601 & (C-27-14)28ddd-2 & 38.427461 & -113.419134 & 987 & 5,085 & 09/05/2012 & 562.4 & 4,523 \\
\hline 382535113251101 & (C-27-14)28ddd-1 & 38.426349 & -113.420523 & 0 & 5,090 & $09 / 05 / 2012$ & 567.7 & 4,522 \\
\hline 380904113380101 & $(\mathrm{C}-30-16) 34 \mathrm{cca}-1$ & 38.151075 & -113.634414 & 170 & 6,230 & 09/05/2012 & 41.9 & 6,188 \\
\hline 380716113374901 & (C-31-16)10cab-1 & 38.121076 & -113.631080 & 150 & 6,135 & 09/05/2012 & 8.9 & 6,126 \\
\hline 381033113480701 & (C-30-18)25aad-1 & 38.175796 & -113.802750 & 0 & 7,098 & 09/06/2012 & 5.0 & 7,093 \\
\hline 383357113440601 & (C-26-17) 3cdd-1 & 38.571639 & -113.741972 & 870 & 5,245 & 09/06/2012 & 435.8 & 4,809 \\
\hline 383402113440601 & (C-26-17) 3cda-1 & 38.572861 & -113.742000 & 882 & 5,248 & 09/06/2012 & 433.4 & 4,815 \\
\hline 383303113343201 & (C-25-16)18bdd-1 & 38.640361 & -113.685667 & 340 & 5,085 & 09/06/2012 & 299.8 & 4,785 \\
\hline 383131113214301 & (C-26-14)25aad-1 & 38.525237 & -113.362744 & 1,135 & 4,760 & 09/07/2012 & 233.4 & 4,527 \\
\hline 384042113181601 & $(\mathrm{C}-24-13) 34 \mathrm{ccb}-1$ & 38.678167 & -113.305222 & 294 & 4,645 & 09/07/2012 & 209.5 & 4,436 \\
\hline 384215113165701 & (C-24-13)23ccd-1 & 38.704124 & -113.283298 & 201 & 4,619 & $09 / 07 / 2012$ & 177.0 & 4,442 \\
\hline 384306113112601 & $(\mathrm{C}-24-12) 15 \mathrm{cdc}-1$ & 38.718292 & -113.191350 & 532 & 4,595 & 09/07/2012 & 83.3 & 4,512 \\
\hline 384351113150501 & (C-24-13)13aac-1 & 38.730791 & -113.252186 & 145 & 4,555 & 09/07/2012 & 95.6 & 4,460 \\
\hline 385008113145301 & $(\mathrm{C}-23-12) 6 \mathrm{ccd}-1$ & 38.835512 & -113.248853 & 560 & 4,632 & 09/07/2012 & 205.5 & 4,427 \\
\hline${ }^{2} 383538113450801$ & (C-25-17)33dab-1 & 38.593845 & -113.753032 & 628 & 5,265 & $07 / 01 / 1933$ & 466.0 & 4,799 \\
\hline$-^{1}$ & (C-31-16)32aca & 38.066798 & -113.658773 & 217 & 5,980 & $07 / 08 / 2008$ & 185 & 5,795 \\
\hline$-^{1}$ & $(\mathrm{C}-31-16) 21 \mathrm{abb}$ & 38.098263 & -113.646686 & 300 & 6,050 & $02 / 10 / 2004$ & 180 & 5,870 \\
\hline 381152113442801 & (C-30-17)15cab-1 & 38.197880 & -113.741408 & 385 & 6,550 & $11 / 22 / 1995$ & 350 & 6,200 \\
\hline 2383226113412401 & (C-26-16)19bbd-1 & 38.540513 & -113.690808 & 394 & 5,205 & 01/01/1960 & 355 & 4,850 \\
\hline 382016113364001 & (C-28-16)35bac-S1 & 38.337739 & -113.611915 & - & 7,210 & $-^{4}$ & - & 7,210 \\
\hline 381700113383001 & (C-29-16)16dca-S1 & 38.283295 & -113.642471 & - & 7,280 & $-^{4}$ & - & 7,280 \\
\hline 381045113470701 & (C-30-17)19ddc-S1 & 38.179129 & -113.786083 & - & 6,900 & $-^{4}$ & - & 6,900 \\
\hline 382151113512301 & (C-28-18)22bbc-S1 & 38.364126 & -113.857198 & - & 6,585 & $-^{4}$ & - & 6,585 \\
\hline
\end{tabular}


Table A-1. Selected attributes of wells and water levels measured in wells used in constructing the water-level surface map for Pine and Wah Wah Valleys and surrounding areas, Utah.-Continued

[Horizontal coordinate information is referenced to the North American Datum of 1983 (NAD 83). Abbreviations: USGS, U.S. Geological Survey; mm/dd/ yyyy, month/day/year; -, no information; <, less than]

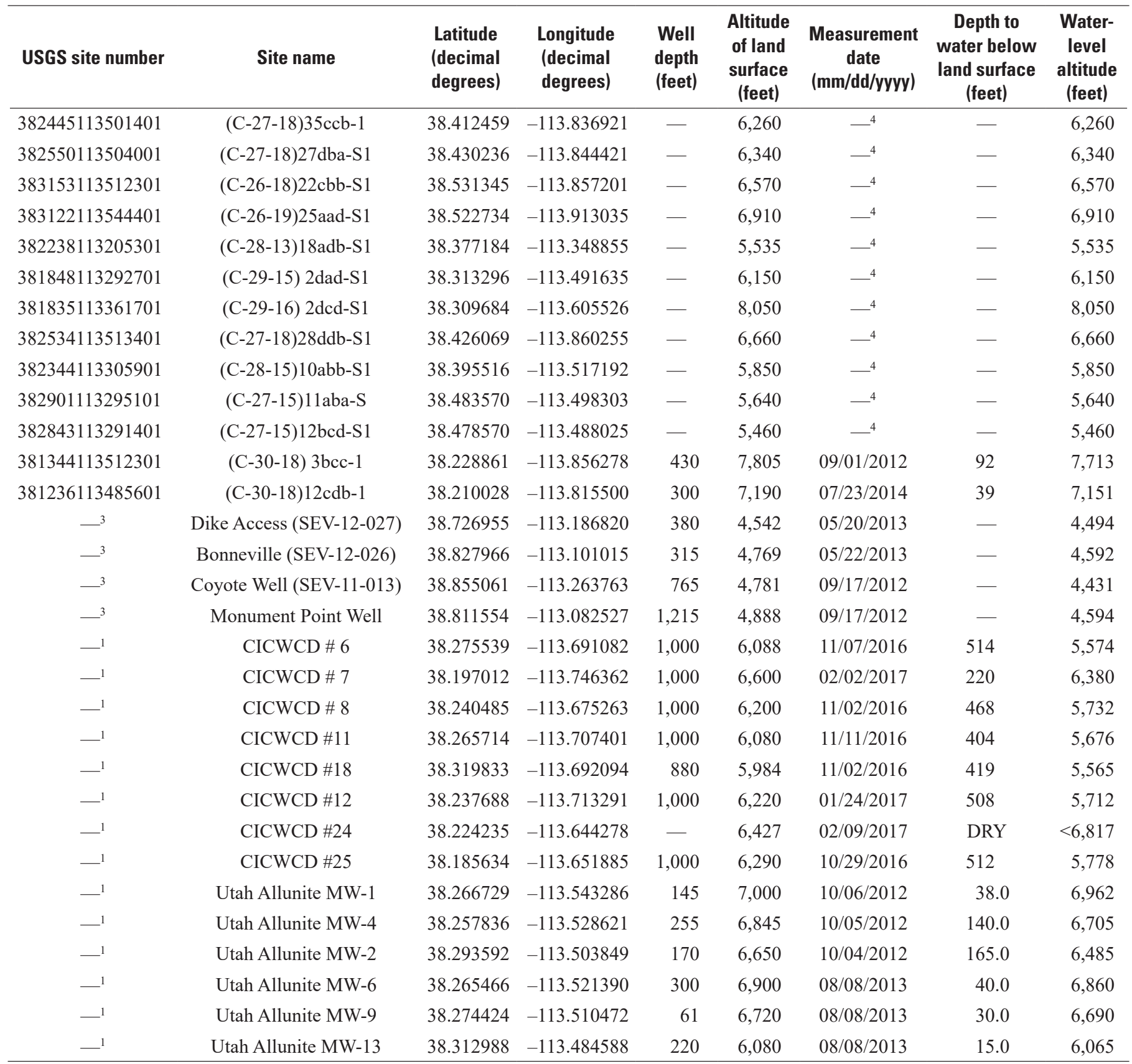

${ }^{1}$ Water level was not in the USGS database. It was obtained from drillers log filed with the Utah State Division of Water Rights and available at https://waterrights.utah.gov/.

${ }^{2}$ Water level was obtained from the driller's log and reported in the USGS database.

${ }^{3}$ Water level was not in the USGS database. The water-level altitudes were reported by Stephen Hill with CH2MHill (written commun., January 21, 2014).

${ }^{4}$ Land-surface altitude is used to approximate the altitude of the groundwater level at springs; no date is associated. 

For more information concerning the research in this report, contact the Director, Utah Water Science Center

U.S. Geological Survey

2329 West Orton Circle

Salt Lake City, Utah 84119-2047

801-908-5000

https://ut.water.usgs.gov

Publishing support provided by the U.S. Geological Survey Science Publishing Network, Sacramento Publishing Service Center 


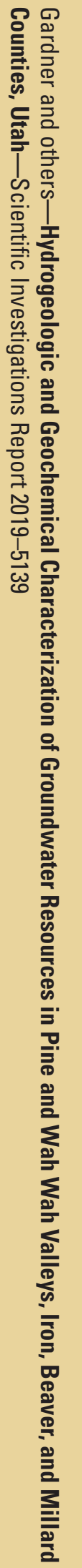

